Portland State University

PDXScholar

\title{
Late Holocene Paleoseismicity along the Northern Oregon Coast
}

Mark Edward Darienzo

Portland State University

Follow this and additional works at: https://pdxscholar.library.pdx.edu/open_access_etds

Part of the Geology Commons

Let us know how access to this document benefits you.

\section{Recommended Citation}

Darienzo, Mark Edward, "Late Holocene Paleoseismicity along the Northern Oregon Coast" (1991). Dissertations and Theses. Paper 1147.

https://doi.org/10.15760/etd.1146

This Dissertation is brought to you for free and open access. It has been accepted for inclusion in Dissertations and Theses by an authorized administrator of PDXScholar. Please contact us if we can make this document more accessible: pdxscholar@pdx.edu. 
LATE HOLOCENE PALEOSEISMICITY ALONG THE NORTHERN OREGON COAST

\author{
by
MARK EDWARD DARIENZO
}

A dissertation submitted in partial fulfillment of the requirements for the degree of

DOCTOR OF PHILOSOPHY in

ENVIRONMENTAL SCIENCES AND RESOURCES: GEOLOGY

Portland State University

1991 
TO THE OFFICE OF GRADUATE STUDIES

The members of the Cornmittee approve the dissertation of Mark Edward Darienzo presented August 26, 1991.
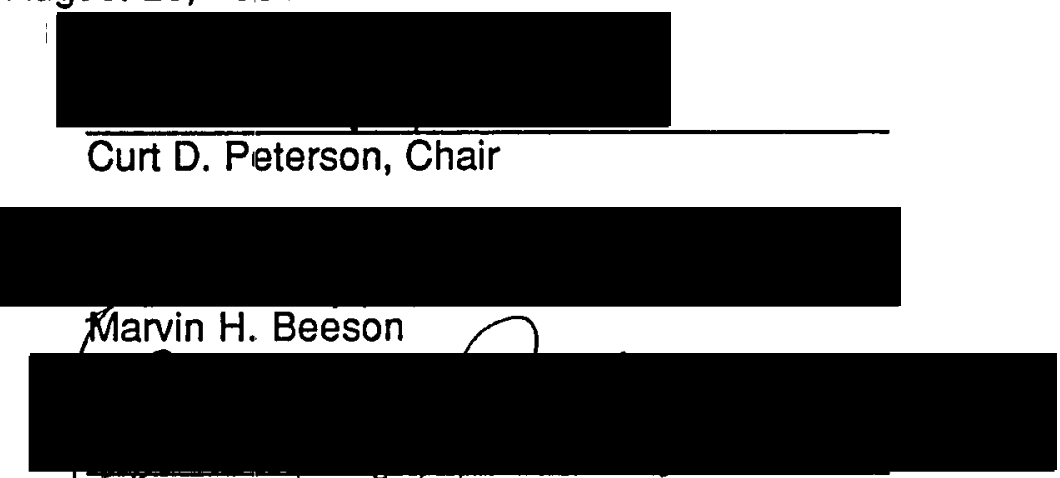

Ánsel G. Johinson

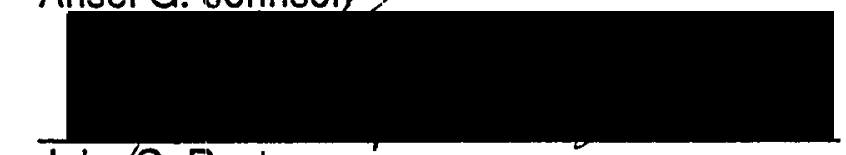

John/G. Rueter

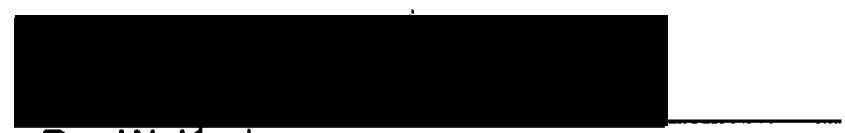

Roy W. Koch

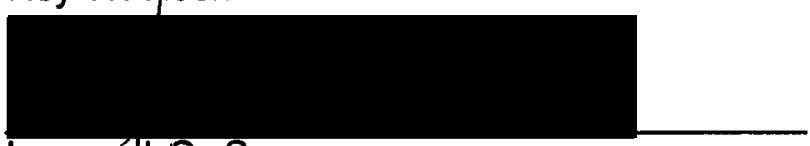

Leonard, G. Swanson

APPROVED:

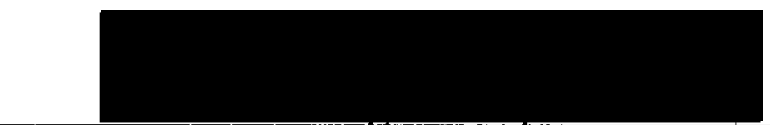

Pavel K. Smejtek, Director, Environmental Sciences and Resources Program

C. William Savery, Vice Provost for Graduate Studies and Research 
AN ABSTRACT OF THE DISSERTATION OF Mark Edward Darienzo for the Doctor of Philosophy in Environmental Sciences and Resources/Geology presented August 26, 1991.

Title: Late Holocene Paleoseismicity along the Northern Oregon Coast. APPROVED BY THE MEMBERS OF THE DISSERTATION COMMITTEE:

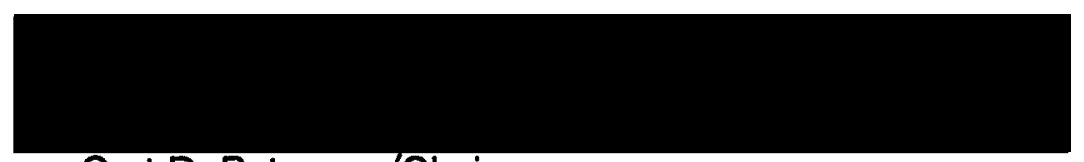

Curt D. Peterson,'Chair

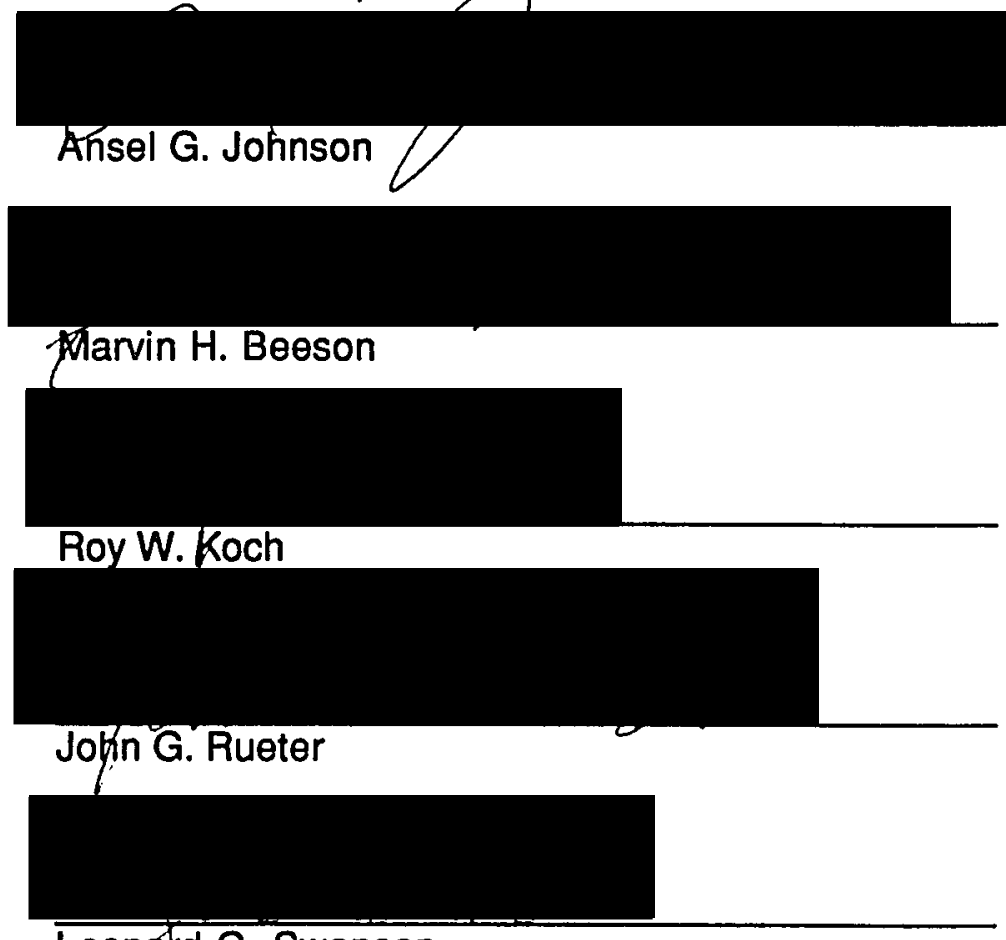

Leonáxd G. Swanson 
Marsh paleoseismological studies were conducted in four bays (Necanicum, Nestucca, Siletz, and Yaquina) along the northern Oregon coast and compared with completed studies in two other bays (Netarts and Alsea). Coseismically buried peats were identified in all bays, based on 1) abrupt contacts, decreases in organic content, increases in sand content, increases in beach sand, and changes in diatom assemblages, all from the peat to the overlying sediments, 2) distinct sandy layers and key plant macrofossils, such as Triglochin, above the buried peat, and 3) widespread correlation of the buried peats within the bay. The stratigraphy and the ages and depths of the top six coseismically buried peats were compared between bays. The following similarities were noted: 1) All bays recorded five burial events in the top 2.6 meters within the last 2200 years. 2) Six burial events were recorded in six bays in the top 3.0 meters, except Alsea Bay ( $3.3 \mathrm{~m})$, and all six events occurred within the last 2600 years except Yaquina (2780 years). 3) The depth to the top of each buried peat in the bays is consistent, falling within discrete ranges, except for the top two events at Yaquina. 4) Distinct sandy layers (tsunamideposited) are present over the topmost buried peat in all bays except Yaquina and over the 4th in all bays except Yaquina and Nestucca. 5) Distinct tsunamideposited sandy layers are absent over the third buried peat in Netarts, Nestucca, Siletz, Alsea, and possibly Yaquina, but present at Necanicum. The evidence strongly suggests synchroneity of coseismic events between the Necanicum River and Alsea Bay (a distance of $175 \mathrm{~km}$ ), with the exception of the 2nd and 6th event. The 6th coseismic event would be synchronous between Alsea and Netarts, a distance of $105 \mathrm{~km}$. The support for synchroneity of the 2nd event is weak. Synchroneity of coseismic burial events on the northern Oregon coast would argue for paleomagnitudes of at least $8.1 \mathrm{MW}_{\mathrm{w}}$, 
given a minimum rupture width of $50 \mathrm{~km}$ and a rupture length of $105 \mathrm{~km}$. The paleomagnitudes were determined using the moment magnitude equation, $M_{w}$ $=2 / 3 \log _{10} M_{0}-10.7$ where $M_{0}=$ shear modulus $\times$ rupture area $\times$ seismic slip. The seismic slip is estimated from a minimum recurrence interval of 300 years and a minimum convergence rate of $3.5 \mathrm{~cm} / \mathrm{yr}$. 


\section{ACKNOWLEDGEMENTS}

l'd like to thank my advisor, Curt Peterson, for his support over the years we've been working together. I would also like to acknowledge the other members of my committee, Marvin Beeson, Ansel Johnson, John Rueter and Roy Koch, for their comments that improved the thesis. Special thanks to Charles Clough for his invaluable assistance in the field, the lab and behind the computer. A thank you also goes to Margot Truini, Ingmar Saul, Rick Mulder, the vibracore dudes, David Jones and Mark Hansen, for their help in the field and with laboratory analyses, and to Doann Hamilton and Suzan Clough for assisting with figure drafting. Thanks also to Gene Pierson who assisted with vibracore construction, to Brian Atwater for showing me how to identify macrofossils, and to Wendy Grant for sharing her data from Nehalem and Salmon. I'm grateful to Henry Pittock for his assistance in determining core site tidal elevations. Thanks to Richard Peterson for allowing me the use of the Biology walk-in cooler to store our cores and lab space to describe them. Thanks also to the Biology Department for allowing us the use of a room to split the vibracores. This thesis was supported by the U.S. Geological Survey National Earthquake Hazards Reduction Program and National Science Foundation, and the State of Oregon Department of Geology and Mineral Industries grants, the Portland State University Geology Department and the Environmental Sciences and Resources Program. This thesis is for Celeste Garcia who has been with me through it all. 


\section{TABLE OF CONTENTS}

PAGE

ACKNOWLEDGEMENTS........................................................................... iii

LIST OF TABLES.......................................................................................................... vii

LIST OF FIGURES.................................................................................................... viii

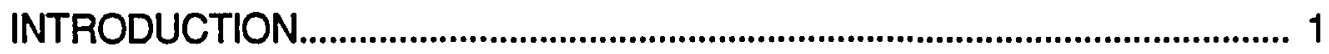

BACKGROUND

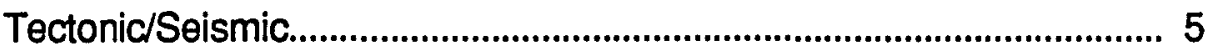

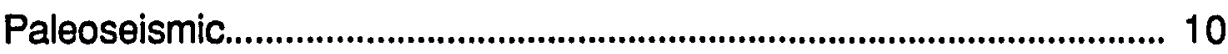

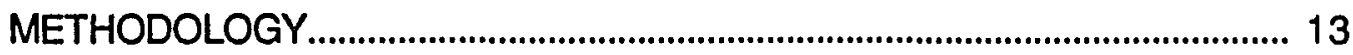

Determination of Coseismic Marsh Burial......................................... 13

Establishment of Synchroneity.................................................................... 17

Calculation of Paleomagnitude................................................................. 18

RESULTS......................................................................................................... 20

Necanicum River............................................................................. 20

Hydrography and Physiography

Core Locations and Tidal Elevations

Detailed Stratigraphy

Laboratory Analyses

Radiocarbon Ages

Netarts Bay. 32

Hydrography and Physiography Core Locations and Tidal Elevations

Detailed Stratigraphy 
Laboratory Analyses

Radiocarbon Ages

Nestucca Bay.

Hydrography and Physiography

Core Locations and Tidal Elevations

Detailed Stratigraphy

Laboratory Analyses

Radiocarbon Ages

Siletz Bay 55

Hydrography and Physiography

Core Locations and Tidal Elevations

Detailed Stratigraphy

Laboratory Analyses

Radiocarbon Ages

Yaquina Bay.

Hydrography and Physiography

Core Locations and Tidal Elevations

Detailed Stratigraphy

Laboratory Analyses

Radiocarbon Áges

Alsea Bay.

75

Hydrography and Physiography

Core Locations and Tidal Elevations

Detailed Stratigraphy

Laboratory Analyses

Radiocarbon Ages

DISCUSSION

83

Coseismic Marsh Burial.

Necanicum River

Netarts Bay

Nestucca Bay

Siletz Bay

Yaquina Bay

Alsea Bay 
Synchroneity of Events....................................................................... 113

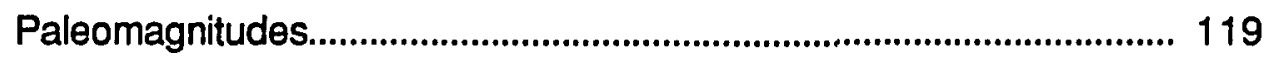

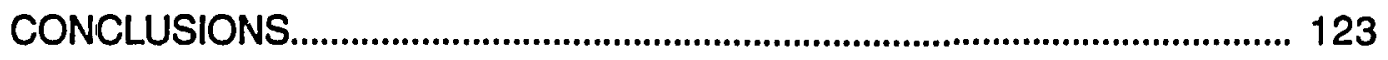

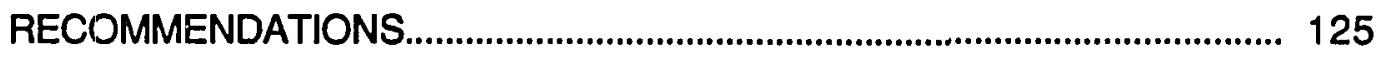

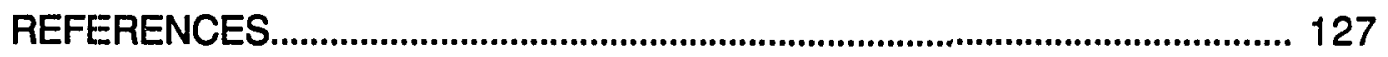

APPENDICES

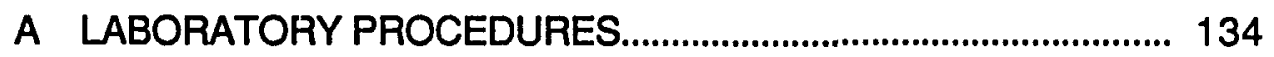

B SEDIMENT CLASSIFICATION......................................................... 138

C PERCENT LOSS ON IGNITION COMPARISONS......................... 140

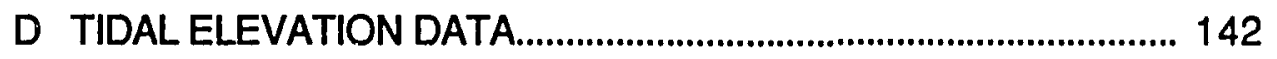

E SUMMARY OF HYDROGRAPHY AND PHYSIOGRAPHY

DATA FROM ALL BAYS....................................................... 149

F RESULTS OF LABORATORY ANALYSES..................................... 152

G DIATOM AND SALT MARSH PLANT SPECIES............................ 166 


\section{LIST OF TABLES}

TABLE

PAGE

1 Percent Beach Sand in Burial Horizons of Three Core Sites in the Necanicum Estuary............................................................. 31

II Percent Beach Sand in Burial Horizons of Core Sites in Notarts Bay

III Percent Beach Sand in Burial Horizons of Core Sites in Nestucca Bay......................................................................... 52

IV Summary of Evidence for Coseismic Burial Events in

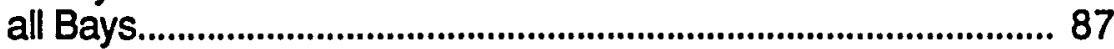

V Ranges of Depth to the Top of the Buried Peat Horizons for All Bays.

VI Radiocarbon Age (RCYBP) Ranges for the Buried Peats for All Bays................................................................................ 116 


\section{LIST OF FIGURES}

FIGURE

PAGE

1. Regional Map with Locations of Bays Studied........................... 3

2. General Tectonics Map of the Pacific Northwest......................... 6

3. Simplified Cross Section of Plate Subduction and Deformation Cycles (modified from Ando and Balazs, 1979)

4. The Necanicum Estuary with Location of Core Sites and Cutbank Exposures

5. Stratigraphy of Cores from Sites in the Upper Tidal Reaches of Neawanna Creek.

6. Stratigraphy of Additional Cores from Sites along the Length of the Neawanna............................................................ 25

7. Stratigraphy of Cutbanks along the Length of the Neawanna.. 26

8. Plot of Burial Horizons vs. Percent Loss on Ignition and Percent Sand for Neawanna 2.

9. Plot of Burial Horizons vs. Percent Loss on Ignition and Percent Sand for Neawanna 5.

10. Plot of Burial Horizons vs. Percent Loss on lgnition and Percent Sand for Neawanna 7.

11. Radiocarbon Ages of the Buried Peats from Neawanna 2.

12. Netarts Bay General Setting and Location of Salt Marsh Core Sites.

13. Stratigraphy of Netarts Bay Cores from Sites on a West to East Transect in the Southern Part of the Bay

14. Stratigraphy of Netarts Bay Cores from Sites on a North to South Transect in the Southern Part of the Bay. 
15. Stratigraphy of the Cores from Sites in the Central and Northern Part of Netarts Bay............................................ 37

16. Radiocarbon Ages of Buried Peats in Netarts Bay....................... 42

17. General Setting and Core Site Locations of Nestucca Bay on Marsh (short dashes) or Pastureland (long dashes) ....... 43

18. Stratigraphy of the Hurliman and Little Nestucca cores.............. 46

19. Stratigraphy of Additional Cores from Sites in the Lower Reaches of the Little Nestucca River......................................... 47

20. Stratigraphy of the Nestucca Duck Cores across from the North Spit................................................................................. 48

21. Plot of Burial Horizons vs. Percent Loss on Ignition and Percent Sand for Little Nestucca 5............................................. 50

22. Plot of Burial Horizons vs. Percent Loss on Ignition and Percent Sand for Hurliman 2........................................................ 51

23. Radiocarbon Ages of Buried Peats from Hurliman 2................... 53

24. Radiocarbon Ages of Buried Peats from Little Nestucca 5......... 54

25. General Setting and Core site and Cutbank Locations on Marsh (short dashes) or Pastureland (long dashes) for Siletz Bay.

26. Stratigraphy of the Cores from Sites on the Siletz Spit and Millport Slough 58

27. Stratigraphy of the Cores from Additional Sites in Siletz Bay 59

28. Stratigraphy of Cutbanks along Millport Slough............................. 60

29. Plot of Burial Horizons vs. Percent Loss on Ignition and Percent Sand for Salishan House.

30. Plot of Burial Horizons vs. Percent Loss on Ignition and Percent Sand for Millport 1 62

31. Radiocarbon Ages of the Buried Peats from Salishan House... 64

32. Radiocarbon Ages of the Buried Peats from Millport 1 65 
33. General Setting and Core Site and Cutbank Locations on Marsh or Pastureland in Yaquina Bay....................................... 66

34. Stratigraphy of the Slack Cores from Sites in the Upper Tidal Reaches of the Yaquina River.

35. Stratigraphy of the Conser, Toledo and Blind Cores from Sites in the Upper Reaches of the Yaquina River.................... 69

36. Stratigraphy of the Oysterville Cores from Sites along Poole Slough near the Central Reaches of the Yaquina...... 70

37. Stratigraphy of the Cutbanks along Poole Slough........................ 71

38. Stratigraphy of the Hatfield Cores from a Site in the Lower Reach of the Yaquina Estuary.

39. Plot of Burial Horizons vs. Percent Loss on Ignition and Percent Sand for Slack 1.

40. Plot of Burial Horizons vs. Percent Loss on Ignition and Percent Sand for Oysterville 2.

41. Plot of Burial Horizons vs. Percent Loss on Ignition and Percent Sand for Hatfield.

42. Radiocarbon Ages of the Buried Peats from Slack 1 and CBB Cutbank

43. Radiocarbon Ages of the Buried Peats from Hatfield. 77

44. General Setting and Core Site Locations in the Marshes of Alsea Bay.

45. Stratigraphy of the Cores from the Western Section of the Marsh System in Alsea Bay.

46. Stratigraphy of the Cores from the Central Section of the Marsh System in Alsea Bay.

47. Stratigraphy of the Cores from the Eastern Section of the Marsh System in Alsea Bay.

48. Radiocarbon Ages of the Buried Peats from AB9 82

49. Plot of the Depth to the Top of the Buried Peat vs. Burial Horizon for Each Bay Studied. 
50. Stratigraphy and Radiocarbon Ages of Typical Cutbank Locations from Nehalem and Salmon (modified from Grant, personal communication, 1991).

51. The along-coast extent of three possible paleoearthquakes between Alsea Bay and Grays Harbor and their estimated magnitudes $\left(\mathrm{MW}_{\mathrm{W}}\right)$ 


\section{INTRODUCTION}

Recently, there has been much controversy concerning the potential for a great (>8 moment magnitude $\left(M_{w}\right)$ ) subduction zone earthquake in the Pacific Northwest (Heaton and Kanamori, 1984). Although there have been large $\left(M_{W}\right.$ 6) and major ( $\left.M_{w} 7\right)$ earthquakes recorded in historic times (last 150 years), there has been no record of great earthquakes in the Pacific Northwest during that time. If great earthquakes have occurred in the recent past, there should be evidence in the Holocene geologic record. Over the last four years, the subsurface of coastal wetlands in bays of Oregon, Washington, and northern California have been examined and convincing evidence for several great earthquakes in the last 5000 years has been documented (Atwater, 1987; Darienzo and Peterson, 1990; Grant, 1989; Grant and McLaren, 1987; Nelson, 1987; Peterson and Darienzo, 1991; Reinhart and Bourgeois, 1987 and 1989; Vick, 1988).

A logical next step would be to use these paleoearthquake events in individual bays to determine synchroneity of the events between bays, and from that estimate the magnitudes (using rupture length and width) of the paleoearthquakes. Synchroneity of coseismic events between bays would provide limits on the length of earthquake rupture along the coast. Estimates of rupture width would be more difficult to determine from the stratigraphy, because part of the record would be offshore. Estimates of rupture width (90$100 \mathrm{~km}$ ), which have been offered by Clarke (1991) and Savage and Lisowski (1991) based on offshore tectonics and crustal strain measurements, 
respectively, are fairly consistent. Therefore, the rupture length, as determined by synchroneity of events, would be the key parameter in paleomagnitude determinations.

Synchroneity and magnitude determination of the last event between widespread estuaries have been attempted based on radiocarbon ages alone (Grant et al, 1989). No attempt has been made to strengthen the radiocarbon age-based synchroneity hypothesis by examining various earthquake related parameters documented by the burial events, e.g. presence of sandy tsunami deposit, degree of development of peats prior to burial, as well as the number of events within a specific period of time, and comparing these parameters between individual estuaries. Once such correlations are established it would be possible to calculate paleomagnitudes of the synchronous burial events in a given segment based on formulas that use rupture length (coastline distance of event synchroneity) and estimates of rupture width (Wyss, 1979; Rogers, 1988; Kanamori, 1977; Davis et al, 1990).

This study will focus on the northern Oregon coast between Alsea Bay and the Necanicum River (Figure 1). This $175 \mathrm{~km}$ segment of coastline was chosen, because there have been prior detailed studies of marsh paleoseismology in four estuaries and preliminary studies in three others within this segment. This study is a unique approach to paleoseismology in the Pacific Northwest, with potential application to marsh paleoseismological studies in other segments of the Cascadia subduction zone and possible integration of thase segments into paleomagnitude calculations. This knowledge can also be compared to other paleoseismological studies, such as 1) continental shelf/slope deformation, 2) possible earthquake-induced turbidite flows, 3) on-shore Holocene/Late Pleistocene terrace deformation, and 4) historic geodetic leveling strain 


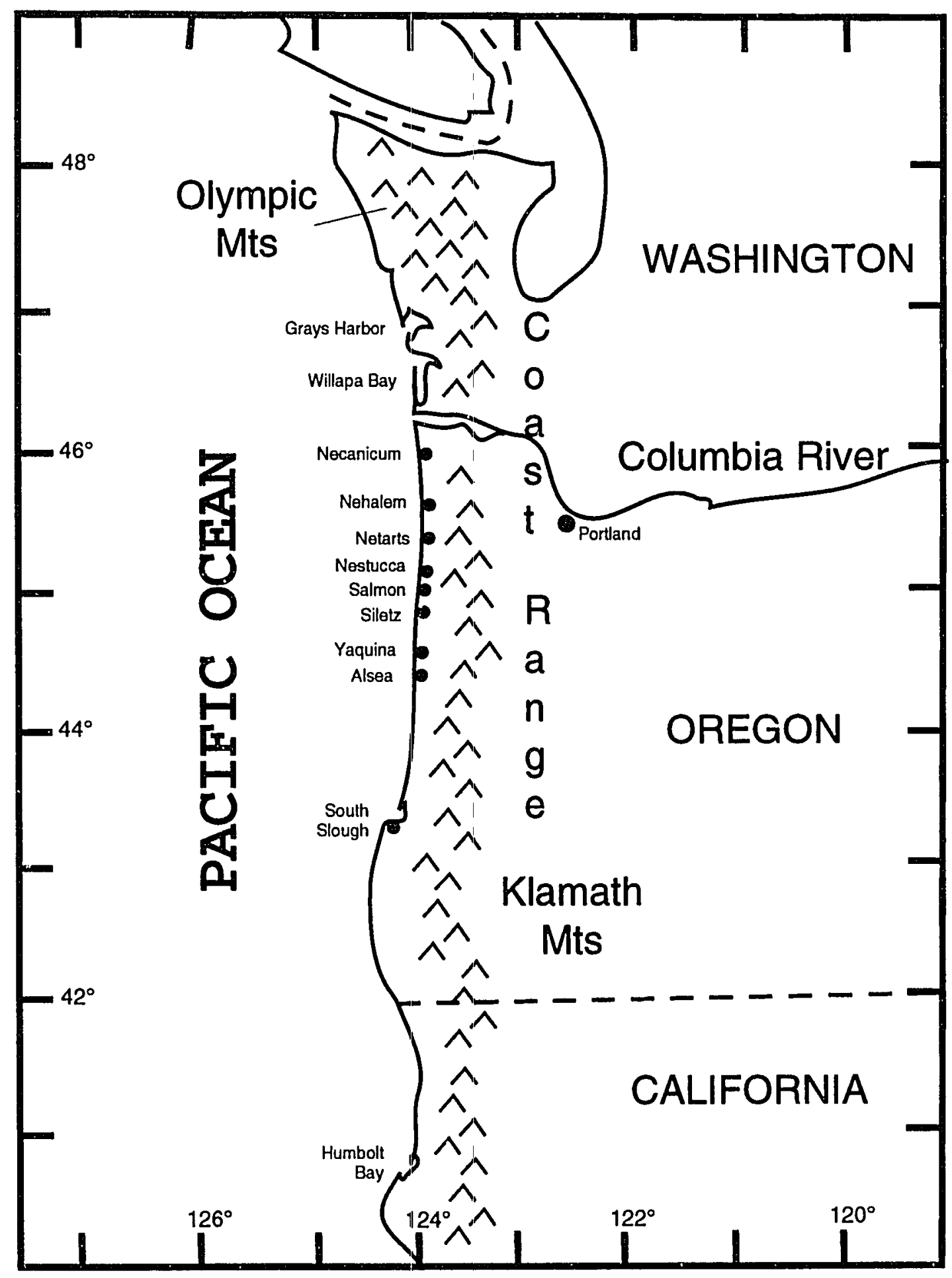

Eigure 1. Regional map with locations of bays studied. 
measurements and tide gauge records, to better understand the prehistoric and historic seismological record of Oregon and Washington.

Ultimately, it's the estimate of energy (i.e. magnitude) produced by the paleoearthquakes and the potential for similar earthquakes in the future that will be of utmost interest to builders and planners in the Pacific Northwest. Oregon is presently classified within seismic zone $2 B$ of the Uniform Building Code only since the 1988 edition. Many of the structures (buildings and bridges) in Oregon built to this code would be damaged by a megathrust (subduction zone) earthquake. Magnitudes of megathrust earthquakes are usually $>8 M_{W}$ (West and McCrumb, 1988). Even small crustal earthquakes less than $7 \mathrm{M}_{\mathrm{w}}$ have been known to cause damage and fatalities (Puget Sound area, 1949) especially in areas with structurally weak buildings or liquefiable soils. In addition, for each unit increase in magnitude, the energy of the earthquake increases 31 times. It would be expected that structural damage and fatalities at a given location would increase with magnitude. Thus, estimates of paleoearthquake magnitudes are important to planners, engineers, and educators in making decisions to upgrade building codes, retrofit critical structurally weak buildings (schools, hospitals, bridges), and institute community awareness and emergency response programs. 


\section{BACKGROUND}

\section{TECTONIC/SEISMIC}

The Juan de Fuca plate, located off the Oregon and Washington continental margin, is a relatively small plate, but a major part of the Cascadia subduction zone (Figure 2). The Cascadia subduction zone also includes the Winona Basin, the Explorer and Gorda plates. Over the last $20 \mathrm{My}$, the plate's area has decreased due to the migrating Mendocino triple junction located near Cape Mendocino (Figure 2) and in the last $10 \mathrm{My}$, the Juan de Fuca ridge spreading rate has slowed (Riddihough, 1984). At present, the Juan de Fuca plate is subducting under and converging with the North American plate at a rate of $3.5-4.5 \mathrm{~cm} / \mathrm{yr}$ and in an approximate NE direction (Heaton and Hartzell, 1987; Weaver and Baker, 1988).

Heaton and Kanamori (1984) argued that there is a potential for a great megathrust earthquake $\left(M_{w}>8\right)$ in the Pacific Northwest. Their argument was based on comparison of the Cascadia subduction zone to seismically active subduction zones elsewhere, e.g., southern Chile where the largest historical earthquake ( $M_{w}$ 9.5) occurred (Plafker, 1972). They compared several characteristics, including degree of seismicity, angle of dip, and age of the subducting plate. Rogers (1988) also made similar comparisons and concluded that the characteristics (low seismicity, young age and size) of the Rivera plate off Mexico (site of the 1932 Jalisco 8.1 $\mathrm{M}_{\mathrm{W}}$ earthquake) are most akin to the Cascadia subduction zone. 


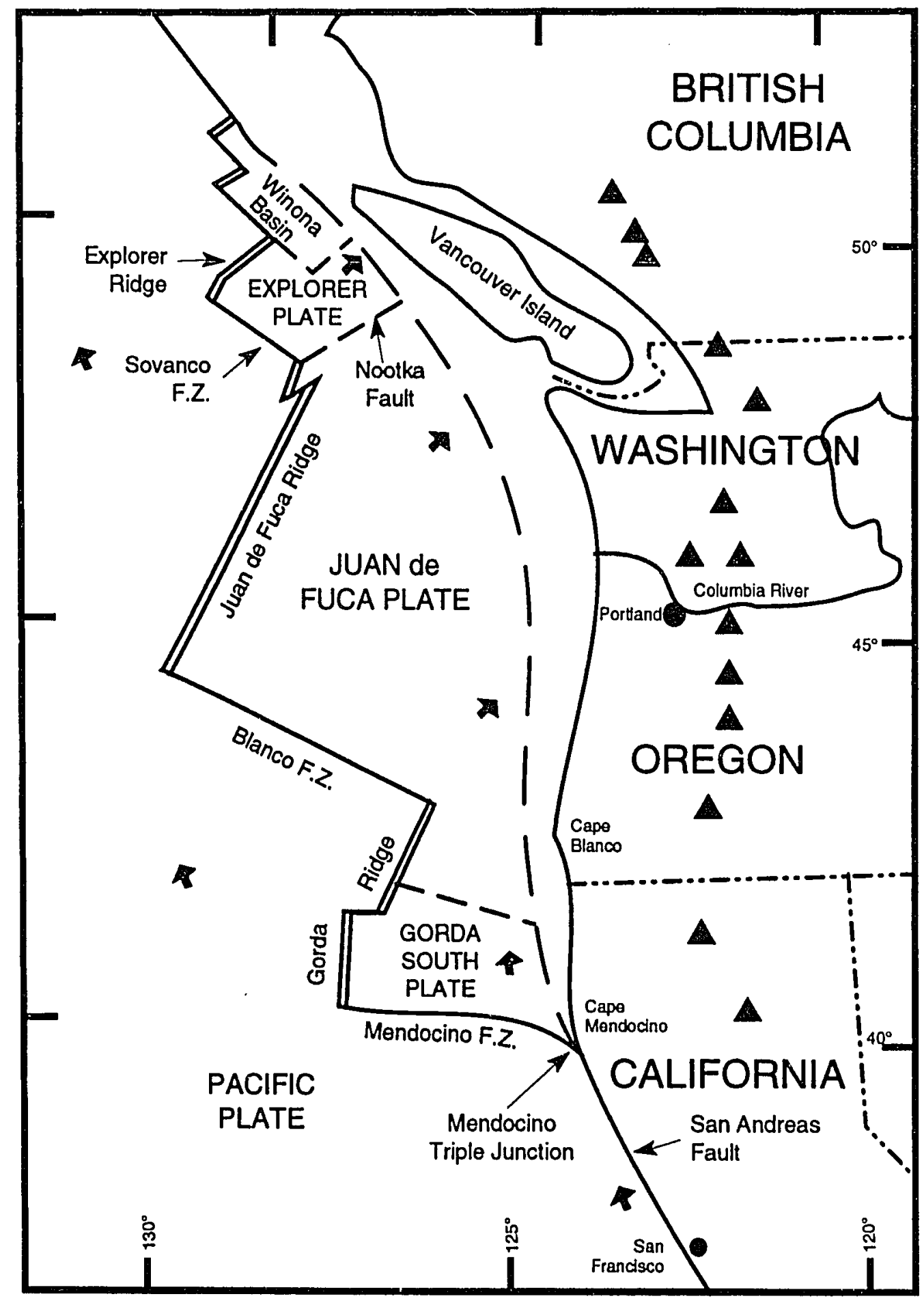

Eiqure 2. General tectonics map of the Pacific Northwest. Bold arrows show plate motion directions. 
Large megathrust earthquakes originate at the interface between the oceanic and continental plates and involve strain accumulation and sudden release (thrust rupture) at that interface (Figure 3). In contrast, the foci (site of initial rupture) of the major and large historical earthquakes in the Pacific Northwest have been in either the subducting Juan de Fuca oceanic plate or in the overriding North American continental plate (Langston and Blum, 1977;

STRAIN ACCUMULATION

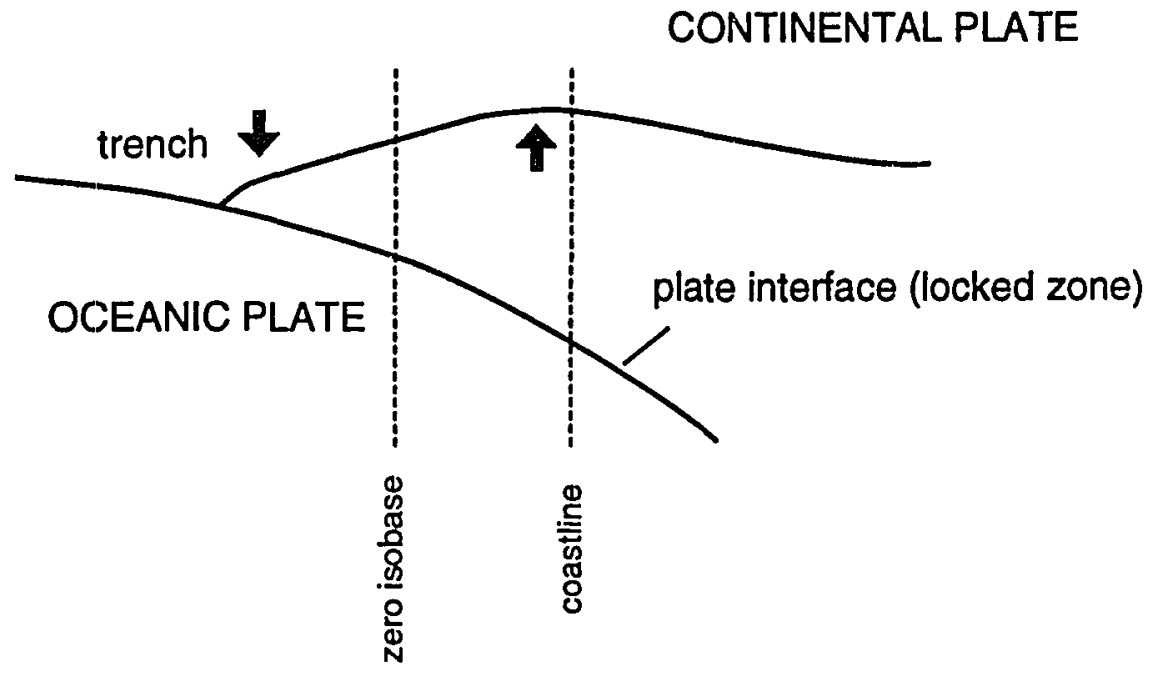

COSEISMIC STRAIN RELEASE

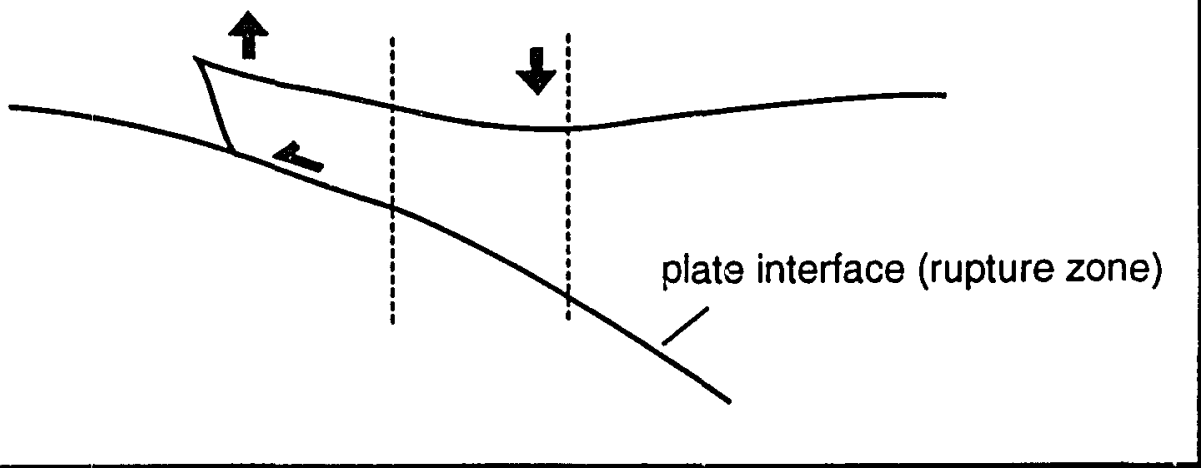

Figure 3. Simplified cross section of plate subduction and deformation cycles (modified from Ando and Balazs, 1979). 
Baker and Langston, 1987). A megathrust earthquake deformation cycle has been modeled by several researchers, based on earthquake and geodetic information from Japan (Figure 3)(Fitch and Scholz, 1971; Thatcher and Rundle, 1984; Savage, 1983). The cycle is characterized by 1) preseismic strain accumulation with vertical deformation both downward (closer to the trench) and upward (farther from the trench), 2) subsequent rupture with coseismic uplift in an area closer to the trench and coseismic subsidence in an area closer to and on land (Figure 3). The vertical deformation associated with strain accumulation is opposite in sign to that occurring during the earthquake.

According to Thatcher (personal communication, 1990), the model is a general rule with exceptions and may not be applicable to the Cascadia subduction zone. For example, prior to the 1960 Chilean and the 1964 Alaskan earthquake there was coseismic subsidence in the area of downward preseismic strain accumulation (Plafker, 1972; Plafker, 1991). There is recent geodetic evidence to indicate that areas that have undergone coseismic subsidence in the Late Holocene in the Pacific Northwest are in an area that might be undergoing upward vertical preseismic strain accumulation and the model would therefore hold (Reilinger and Adams, 1982; Adams, 1984; Vincent et al, 1991; Savage and Lisowski, 1991). The focus of this study will be on the coseismic phase of the cycle.

After the 1960 Chilean and 1964 Alaskan earthquakes, zones of coseismic subsidence (subsidence includes both tectonic subsidence and sediment settling) and uplift were mapped (Plafker, 1972; Plafker and Kachadoorian, 1966). The zone of uplift was trenchward of the zone of subsidence (supporting the dislocation models) and the two zones were separated by a line (zero isobase) in which no vertical movement occurred (see Figure 3 for a general 
model of subduction zone earthquakes). The coastlines and, therefore wetlands, of Chile and Alaska were usually within the zone of subsidence (approximately $100 \mathrm{~km}$ wide). A summary of subsidence estimates for historical subduction zone earthquakes with magnitudes not less than $7.8 M_{w}$ by West and McCrumb (1988) indicate that the amount of subsidence for great earthquakes was at least $0.5 \mathrm{~m}$ and the length of rupture was no less than 130 $\mathrm{km}$. According to Abe (1977), great subduction zone earthquakes normally produce large tsunamis.

Some active subduction zones, such as the Nankai Trough near Japan and the northern Nazca near Columbia, are divided into segments which rupture separately to produce a great earthquake or together to produce an even greater earthquake (Ando, 1975: Kanamori and McNally, 1982). The Cascadia subduction zone has been divided into obvious segments by boundaries such as the Nootka fault and the Blanco fracture zone/Klamath Mountains that separate the Explorer and Gorda plates from the Juan de Fuca plate, respectively (Figure 2) (Riddihough, 1984). However, segmentation within the Juan de Fuca plate is based on less obvious differences, including seismicity of the subduction zone, angle of dip and density of the subducting plate. A possible segment boundary within the study area is $45^{\circ}$ latitude just north of Siletz Bay (Figure 1)(Riddihough, 1984; Michaelson and Weaver, 1986; Spence,1989). Although great earthquakes rupture through segment boundaries (Ando, 1975), awareness of possible boundaries is important in interpreting paleomagnitudes from the marsh records in the bays of northern Oregon. 


\section{PALEOSEISMIC}

Paleoseismological research in the Pacific Northwest was initiated by Atwater (1987) along the coast of Washington. In the last four years, there have been detailed Holocene paleoseismological studies in the coastal wetlands of Oregon (Darienzo and Peterson, 1990; Peterson and Darienzo, 1991; Grant and McLaren, 1987; Grant, 1989; Nelson, 1987) and northern California (Vick, 1988), as well as Washington (Atwater, 1987; Reinhart and Bourgeois, 1987 and 1989). In northern Oregon (north of $44^{\circ}$ latitude) Netarts Bay (Darienzo, 1987; Darienzo and Peterson,1990), Nehalem Bay/Salmon River (Grant and McLaren, 1987), and Alsea Bay (Peterson and Darienzo, 1991) were examined in detail (Figure 1). These studies of salt marsh paleoseismicity cited above have evaluated individual estuaries with respect to 1) documenting evidence of past earthquakes in the subsurface of salt marshes and ruling out other burial mechanisms, such as floods, storms, climatic sea level changes and changes in sand spit morphology, 2) estimating ages of earthquake occurrence and recurrence by radiocarbon dating of organic material from buried peat or forested horizons and 3) estimating the amount of earthquake-induced (coseismic) subsidence. These studies have shown that several great earthquakes have occurred along the northern Oregon coast in the last 4,000 years. Stratigraphically, a single paleoseismic event is characterized by a peaty layer or in situ tree stump and/or roots overlain abruptly by sandy to silty muds which in turn grade upward to another peaty layer. Immediately above the peat or tree stump is, in many cases, a distinctive sandy deposit. In general, this stratigraphy has been interpreted as 1) rapid submergence of a wetland (salt to freshwater marshes and/or low-lying spruce/cedar forests) surface due 
to coseismic subsidence and possibly settling, 2) transport of suspended sediment by an earthquake-generated tsunami and deposition of the sediment on the submerged marsh surface, 3) subsequent burial of the submerged marsh by sediments deposited by normal tidal and/or river processes, and 4) redevelopment of the wetland through sedimentation and post seismic uplift. This sequence is repeated several times in the stratigraphic column.

The earthquake hypothesis in the Pacific Northwest was further strengthened by Atwater and Vita-Finzi (1989) and Bourgeoise and Reinhart (1989) who investigated marshes submerged and subsequently buried as a result of the 1960 Chilean earthquake. They found a stratigraphy (mud overlying sand overlying peat) similar to what was found in the subsurface of marshes irı the Pacific Northwest. Also a study in Alaska found evidence of earthquake-caused sedimentary couplets (buried peats separated by silts) in the Turnagain Arm of the Upper Cook Inlet, located within the subsidence zone of the 1964 earthquake (Bartsch-Winkler and Schmoll, 1987). Recently, Minoura and Nakaya (1991) examined modern and older tsunami deposits in Japan and noted that they had a distinctive chemical signature, indicating that the surge of water came from the ocean side. They also concluded that tsunamis not only carry beach and dune sand landward but erode and redeposit bay bottom sediments. Other corroborating evidence for great earthquakes include the following: 1) Adams (1990) identified 13 turbidite sequences above a Mazama ash layer, with an age of 6845 years B.P., from several widely separated cores off the coast of Oregon and Washington. Turbidites were believed to have been deposited by turbidity currents triggered by 13 great earthquakes on the Cascadia subduction zone between Cape Blanco, Oregon and northern Washington over the last 6700 years. 2) Large 
landslides in Oregon and Washington (Baldwin, 1981; Minor, 1984), have radiocarbon ages similar to the dated buried peat horizons. 3) Coastal Indian legends infer great prehistoric earthquakes and associated tsunamis (Kroeber, 1976; Heaton and Snavely, 1985). 4) Indian middens on the Oregon coast document environmental changes that might be the result of coseismic subsidence from great earthquakes (Woodward et al, 1990; Connolly and Darienzo, 1989)

Basing synchroneity of burial events between bays of the Pacific Northwest on radiocarbon ages alone is difficult. First, the exact age of the burial event can not be pinpointed due to sample contamination inherent in the radiocarbon technique. Second, any sample taken from the surface of the buried marsh would only yield a maximum age for the subsidence event. Four distinct burial events recorded in northernmost Oregon and southern Washington appear to cluster around specific age ranges, indicating possible synchroneity of burial events between Oregon and Washington (300-500, 1000-1300, 1400-1800 and 3000-3300 years B.P.) (Darienzo and Peterson, 1990; Grant, personal communication, 1989; Atwater et al, 1990). Also, analysis of cedar sriag tree rings from various localities along the southwestern Washington coast indicate that a rapid submergence event killed the cedars approximately 300 years ago (Yamaguchi et al, 1989). This age is consistent with the youngest radiocarbon age and is probably the most accurate date for the last earthquake event. Unfortunately, no comparable cedar snags are found in northern Oregon. The use of parameters other than radiocarbon ages is required to prove event synchroneity along the northern Oregon coast. 


\section{METHODOLOGY}

The coastal wetland stratigraphy of Yaquina Bay, Siletz Bay, Nestucca Bay, and Neawanna Creek was examined and compared with detailed information from Netarts and Alsea Bays (Darienzo and Peterson, 1990; Peterson and Darienzo, 1991) and some data from Nehalem Bay and Salmon River (Grant, personal communication, 1991)(Figure 1). The subsurface of these wetlands was first examined for the presence of buried peats of coseismic origin. Next, synchroneity of the burial events in the bays from Neawanna Creek and Alsea Bay was ascertained. And finally, the magnitudes of the paleoearthquakes were estimated.

\section{DETERMINATION OF COSEISMIC MARSH BURIAL}

The subsurface of salt marshes in the four bays was initially examined along cutbanks of rivers and bays and in cores taken with a gouge corer. Cutbank exposures were limited due to 1) small tidal ranges in the bays, 2) slumping along the cutbank, and 3) human manipulation, e.g. diking of the wetlands that made some exposures suspect. The gouge cores $2.5 \mathrm{~cm}$ in diameter) were described in detail and representative cores from each bay were sampled for analyses of grain size (percent sand and silt/clay), organic content (percent loss on ignition), microfossils (presence of freshwater, brackish, or marine diatom assemblages), and heavy minerals (percent beach vs river sand). Heavy mineral slides were prepared and examined for characteristic mineral grains (beach vs river upland source), grain rounding 
(beach-rounded; river-angular) and relative size (with larger grains indicating transport by stronger currents and increased carrying capacity). Additional samples from other cores were also collected for laboratory analyses.

Vibracores $(7.5 \mathrm{~cm}$ in diameter) were taken at gouge core sites that documented at least two of the most complete records in each bay. Drill cores, using an Oregon Department of Transportation hollow stem auger drill rig (10 $\mathrm{cm}$ in diameter), were taken at two sites in Nestucca Bay due to rodding from the vibracoring operation. Rodding is a term used to describe a coring problem in which wood or dry sediment clogs the end of the core tube and pushes softer sediments away as it penetrates the subsurface, therefore decreasing the amount of core recovered. The vibracore and drill cores were also fully described and samples from these cores were 1) used for selected lab analyses (e.g., heavy minerals) and 2) sent to Beta Analytic Inc. (radiocarbon dating laboratory) in Florida for age determinations of buried peats. Cutbanks were also examined and described to confirm core stratigraphic correlations and areal continuity of buried peats. Samples from cutbanks were also collected for radiocarbon age determinations and laboratory analyses such as heavy minerals, if needed, to fill gaps in the core stratigraphic record. Macrofossils from the cores and cutbanks (e.g., Triglochin rhizomes, pine cones and wood fragments) were identified when possible. The laboratory procedures are described in detail in Appendix A.

Detailed qualitative descriptions of the cores were changed based on quantitative measurements of loss on ignition and grain size to more accurately describe the cores. For example, a qualitative muddy peat would be considered a peaty mud owing to its smaller percent loss on ignition. Folk's (1980) percentage system was used for classifying sediments and a slightly 
modified version of a percentage system for Alsea and Netarts Bays (Darienzo and Peterson, 1990; Peterson and Darienzo, 1991) was used for classifying organics in Necanicum, Nestucca, Siletz, and Yaquina (Franklin et al, 1973) (Appendix B). Instead of igniting at $380^{\circ} \mathrm{C}$ for $\geq 10$ hours, the samples were ignited at $450^{\circ} \mathrm{C}$ for 5 hours, because of the large number of samples processed and the belief that the percentages would not be significantly different. To test this, samples from Wee Willies and Little Nestucca 5 were processed using both methods. The results are shown in Appendix $C$. The values for $380^{\circ} \mathrm{C}$ were almost always less than the $450^{\circ} \mathrm{C}$ values, ranging from $<1$ to $27 \%$ less. Usually the greater the percent loss on ignition (LOI), the greater the difference. So to reasonably compare the LOI data from Alsea and Netarts Bays with the other bays, a 12\% (average of the differences) adjustment was made in the classification system for those bays.

Stratigraphic columns from the detailed descriptions and location maps were produced using drafting software. All laboratory data, burial unit components (MT, S, SCL) and their corresponding depths below the surface and elevations with respect to modern mean tide level, and radiocarbon ages were entered onto plot-producing spread sheets.

The following criteria were used (Darienzo, 1987; Darienzo and Peterson, 1990; Peterson and Darienzo, 1991) to indicate rapid changes in depositional environment and thus coseismic burial events: 1 ) an abrupt ( $<1 \mathrm{~cm}$ transition) contact between peat and either a) overlying anomalous, structureless sandy deposits overlain in turn by laminated sediments or b) overlying laminated sediments, 2) gradual contacts between the buried peat and underlying lower organic sediments indicating gradual redevelopment of marsh, 3) significant changes in inorganic and organic sediment content from the peat top to the 
overlying sediments, 4) freshwater diatoms in the peat layer overlain by estuarine/marine diatoms in both the anomalous sandy layer and laminated layer, 5) in situ high marsh peats (with characteristic high marsh macrofossils) overlain by Triglochin maritimum rhizomes embedded in low organic sediments, 6) increased beach component in the distinct sandy sediment capping layer to distinguish between flood and tsunami/storm deposits, and 7) widespread extent and correlation of burial events within a single estuary. The correlation of burial events from site to site in each bay was based on the following: a) adjusted elevations with respect to mean tide level, b) depth below the modern marsh surface, c) distinctive SCL's (sediment capping layers), d) degree of peat development, and e) radiocarbon ages.

All core sites and various modern forest, marsh and tidal flat locations were surveyed to bench marks if available, using an EDM/theodolite or a hand level/rod/tape measure method. Since bench marks were rarely close by, the core sites and the surfaces of modern marsh and tidal flat environments were usually tied to water level and the time was recorded. The water levels were tied to the mean tide level (MTL) within the bay using the times plus either longterm tidal data from the bays or from adjacent bays (Henry Pittock, College of Oceanography at Oregon State University, 1991). The elevation data is summarized in Appendix D. Core sites and other locations, that were tied to water levels, could now be tied to mean tide levels. This provides a common reference elevation for all core sites in the bay. The core descriptions and laboratory analyses (grain size, organic content, and microfossils) aid in delineating the approximate paleoenvironment of the buried peat surface and overlying deposits (i.e., whether it is high marsh/coastal forest or low marsh/tide flat) (Darienzo and Peterson, 1990; Peterson and Darienzo, 1991). Knowing 
modern depositional environment elevations and the paleoenvironments, elevations of the paleomarsh surfaces were then estimated. From the paleoelevations, estimates of subsidence were calculated. Since subsidence may include a component of settling, it would be important to separate the settling from the tectonic component to better compare this parameter between bays with different sediment and possible settling characteristics. Unfortunately, no quantitative measurements have been made from historical great earthquakes to use as a guide. However, a study in Japan of liquefaction and settlement of saturated sands up to $10 \mathrm{~m}$ thick from earthquake shaking noted that there was no more than $15 \%$ settlement even taking into account estimation errors (Tokimatsu and Seed, 1987). In contrast, the sediments in the marsh cores are quite organic and mud-rich. Therefore, the liquefaction potential would decrease and settlement from shaking would be less (Seed et al, 1984). As a result the settling component of subsidence for events from bays along the Oregon coast is insignificant.

\section{ESTABLISHMENT OF SYNCHRONEITY}

Synchroneity of earthquake burial events between estuaries in northern Oregon is established using the following data: 1) the number of events recorded in each bay, 2) the depth below the surface as well as the elevation with respect to MTL of each event, 3) radiocarbon ages of buried peats, 4) amount of coseismic subsidence based on paleomarsh and paleotideflat elevation estimates, 5) degree of paleomarsh development (forest, freshwater marsh, high salt marsh or low salt marsh), 6) nature and occurrence of tsunamideposited sands immediately overlying the buried peats, and 7) the presence of tsunami-deposited sand within, rather on top of, the buried peat. The presence 
of tsunami-deposited sand within a buried peat would suggest that no subsidence had occurred, but that a tsunami from an earthquake in an adjacent segment might have deposited sand on the marsh surface. Stratigraphy and radiocarbon ages from paleoseismological studies of Nehalem Bay and Salmon River were used in synchroneity determinations and were made available by Wendy Grant of the U.S Geological Survey .

\section{CALCULATION OF PALEOMAGNITUDE}

The moment magnitude $\left(M_{W}\right)$ of an earthquake is determined by the equation $M_{W}=2 / 3 \log _{10} M_{0}-10.7$ (Kanamori, 1983). $M_{0}$ is the seismic moment and is equal to the product of the area of rupture, based on extent of the main shock and aftershocks, the amount of slip along the fault (interface), and a constant called the shear modulus which is based on stiffness of the plate and is usually given as $3 \times 10^{11}$ dynes $/ \mathrm{cm}^{2}$. Another equation used to estimate earthquake magnitude is $M_{\max }=\log A+4.15$, where $A$ is the area of rupture (Wyss, 1979).

A different approach is required to determine the magnitudes of paleoearthquakes. Using Kanamori's equation one needs to estimate 1) an average slip using the mean recurrence interval of the coseismic subsidence events and the rate of convergence (approximately $4.0 \mathrm{~cm} / \mathrm{yr}$ ) of the Juan de Fuca plate with the North American plate (Adams, 1990). The seismic slip is $90 \%$ of the total with the remaining $10 \%$ considered aseismic (Rogers, 1988), 2) a rupture width by a) using known rupture widths from other subduction zones that have similar characteristics to the Juan de Fuca (approximately $100 \mathrm{~km}$ ) (Rogers, 1988) or b) estimates by Savage and Lisowski (1991) of a rupture width off the northern coast of Washington of at least $100 \mathrm{~km}$. In addition, a two 
dimensional dislocation fit model of coseismic vertical movement for the central Cascadia was run using subsidence estimates of marsh burial events from Oregon (north of Siuslaw Bay) and resulted in a rupture width of $90 \mathrm{~km}$ for Oregon (Peterson et al, 1991). Clarke (1991) estimated a locked zone of 70-80 $\mathrm{km}$ and a rupture width of approximately $90 \mathrm{~km}$ for the Gorda segment of the Cascadia subduction zone. Therefore, from the above information, an approximate rupture width of $90-100 \mathrm{~km}$ for paleomagnitude determinations of the northern Oregon coast seems reasonable.

From the measured seismic slip and estimated rupture width and predetermined length of synchronous coastline, the magnitude of a paleoearthquake can be calculated using Kanamori's equation. If Wyss' equation is used only the width and length are required. 


\section{RESULTS}

\section{NECANICUM RIVER}

\section{Hydrography and Physiography}

The Necanicum estuary is approximately $25.7 \mathrm{~km}$ south of the Columbia River and is bounded on the west by a gravel/sand spit and on the east by the Coast Range (Figures 1 and 4). The major tributaries into the bay are the Necanicum River and Neawanna Creek. The drainage is composed mostly of Tertiary marine sedimentary rocks, such as tuffaceous siltstones and sandstones and micaceous sandstones, and minor mafic intrusive rocks (Baldwin, 1981). The Necanicum is $34 \mathrm{~km}$ long and Neawanna Creek is approximately $11 \mathrm{~km}$ long, with the heads of tide at river kilometer 4.3 and 6.1 , respectively. The river-dominated estuary drains an area of $225 \mathrm{sq} . \mathrm{km}$ with an average annual freshwater yield of $2.7 \times 10^{8}$ cubic meters (most of the drainage area and yield is from the Necanicum River). The tidal prism is approximately $1.7 \times 10^{7}$ cubic meters (Percy et al, 1974). Wetlands (salt and freshwater marsh) make up approximately $29.4 \%$ of the estuary with most of the wetlands (60\%) being high salt marsh (Oregon Department of Land Conservation and Development, 1987). Hydrography and physiography data for all bays are summarized in Appendix E. All of the Holocene record of buried peats came from Neawanna Creek. The corer could never penetrate deeper than $50 \mathrm{~cm}$ in the marshes of the Necanicum, either due to underlying cobbles, gravel, or thick sand. 


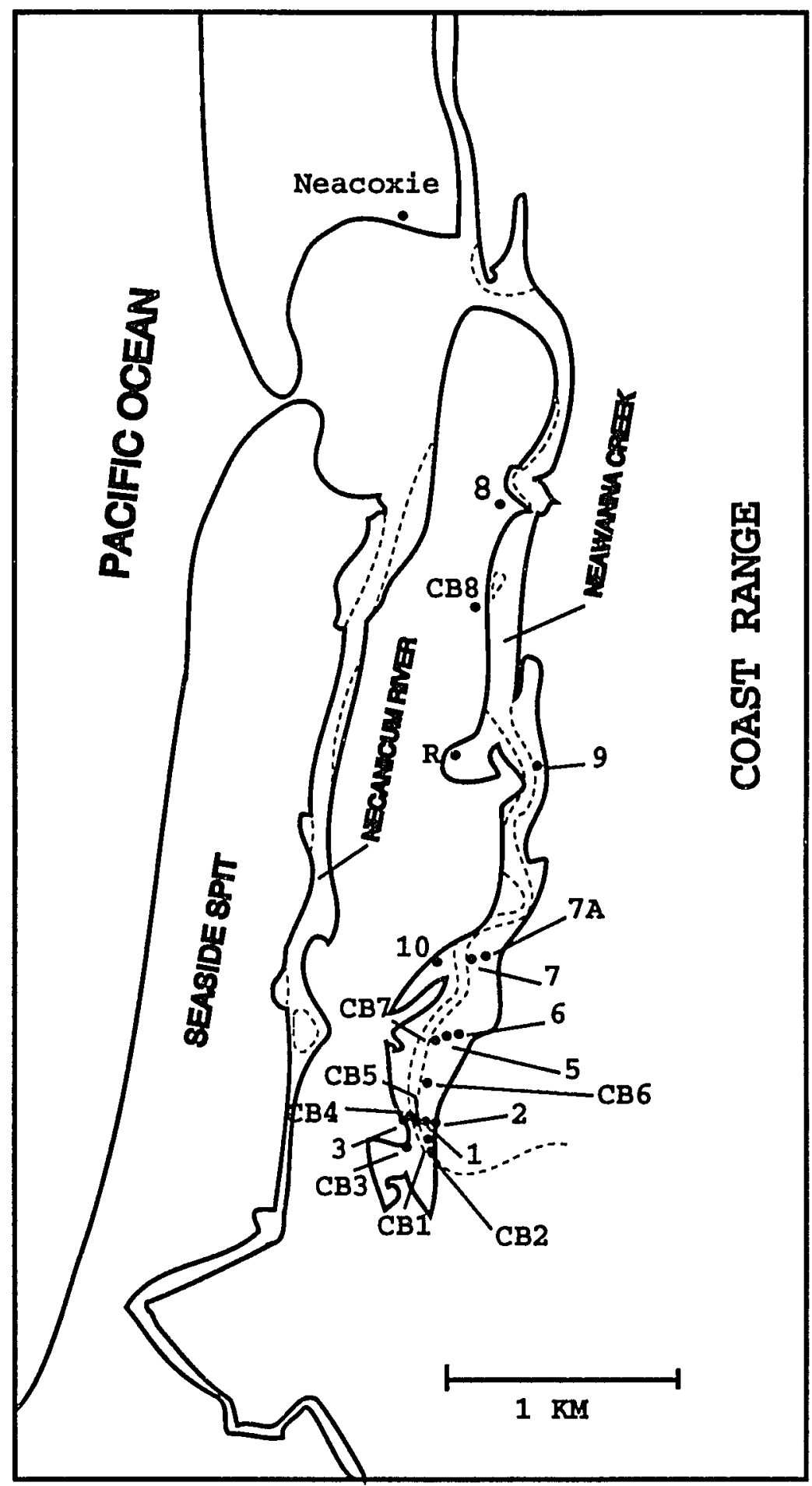

Eigure 4. The Necanicum estuary with location of core sites and cutbank exposures. The dashed line indicates the channel and the area between the dashed and bold lines is marshland. 
The geology consists of a series of NS trending low-lying gravel ridges that have prograded seaward during times of stillstand or sea level drop over the last 3000-4000 years (Rankin, 1983). The ridge that separates the Necanicum River and Neawanna Creek has been established since at least 2550 years B.P. based on a radiocarbon age of an Indian midden site (Tom Connolly personal communication, 1990) and it seems reasonable that marshes did not develop along the Neawanna until after 2550 B.P.

\section{Core Lecations and Tidal Elevations}

In the marshes adjacent to Neawanna Creek, 12 sites were cored with a gouge corer, with two of those sites (Neawanna 2 and 5) cored with a vibracore, and nine cutbank (CB) locations were examined (Figure 4). As mentioned above, the two cores taken along the Necanicum were very shallow and did not record any peat burial events. Most burial events were found in the upper reaches of the Neawanna estuary.

Because no tide gauges were established for Neawanna Creek and the tidal data from the Necanicum could not be conveniently used for the Neawanna, all core sites and cutbank locations were tied into tidal level. In addition, the core locations and four cutbank locations in the upper reaches of Neawanna Creek were tied into a benchmark (PK nail imbedded in a telephone pole) on the west side of the Neawanna Creek road east of core site 7. A benchmark on the highway 101 bridge that crosses the Neawanna, as well as the PK nail benchmark, were also tied into water level. These two water level tie-ins near the mouth and at the head of tide for the creek, plus the data from the tide gauges established along the Necanicum River, aided in determining the mean tidal level for Neawanna. Once a mean tidal level was established, all core sites were tied to mean tidal level. In addition, modern lowland forest, 
high and low marsh and tidal flat sites near the confluence of Neawanna and Neacoxie Creeks were tied into water level (Figure 4).

\section{Detailed Stratigraphy}

The following methodology was applied to core stratigraphic columns from all bays studied. Each stratigraphic column was adjusted up or down depending on the core site's mean tidal elevation and/or elevational relationship with adjacent core sites. The stratigraphic columns were divided into burial units. Each burial unit consists of two or three components or horizons: MT (higher organic-rich sediments or peat top), $S$ (lower organic sediments below MT) and SCL (sediment capping layer that is usually distinguishable from the overlying sediments within its own burial unit and from the peat top in the burial unit below it by increased percentage of sand). In other words, a peat (MT) is buried by the sediments within the overlying burial unit. Occasionally, the sand content increased in the unit above an MT, but a distinct SCL horizon could not be differentiated. In these cases, the horizon was designated as an S. The numbers before the horizon designation (e.g., $1 \mathrm{MT}, 1 \mathrm{~S}, 1 \mathrm{SCL}$ ) indicate a specific burial unit. The larger the number, the deeper the unit. The burial event would therefore be the transition from one burial unit to another, i.e. from a $2 \mathrm{MT}$ to an overlying $1 \mathrm{SCL}$ and/or $1 \mathrm{~S}$.

The stratigraphy of the Neawanna core sites and cutbanks are shown in Figures 5-7. A core (Neawanna $R$ ) was taken in a marsh adjacent to a recess across from Neawanna 9 (see Figure 4), but was not included in the stratigraphic columns. The core contained no buried peats and consisted of a modern peat layer underlain by rooted brownish mud to $1.15 \mathrm{~m}$, black rooted mud to $2.1 \mathrm{~m}$, brown rooted mud to $2.6 \mathrm{~m}$, brown barren mud to 2.85 , brown rooted mud to $3 \mathrm{~m}$, brown barren mud to $3.5 \mathrm{~m}$, and rooted muddy sand to 3.8 


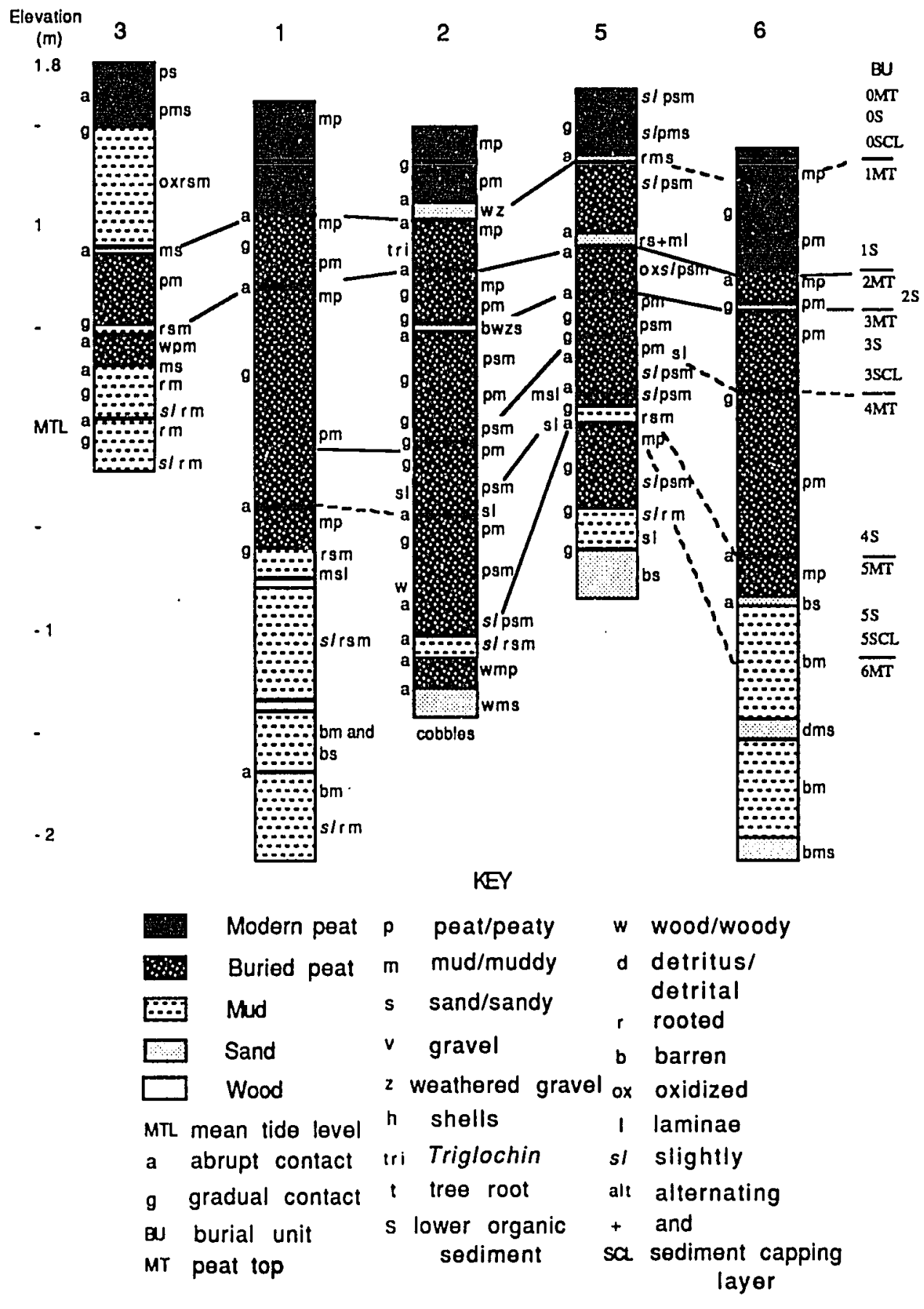

Eiqure 5. Stratigraphy of cores from sites in the upper tidal reaches of Neawanna Creek. 


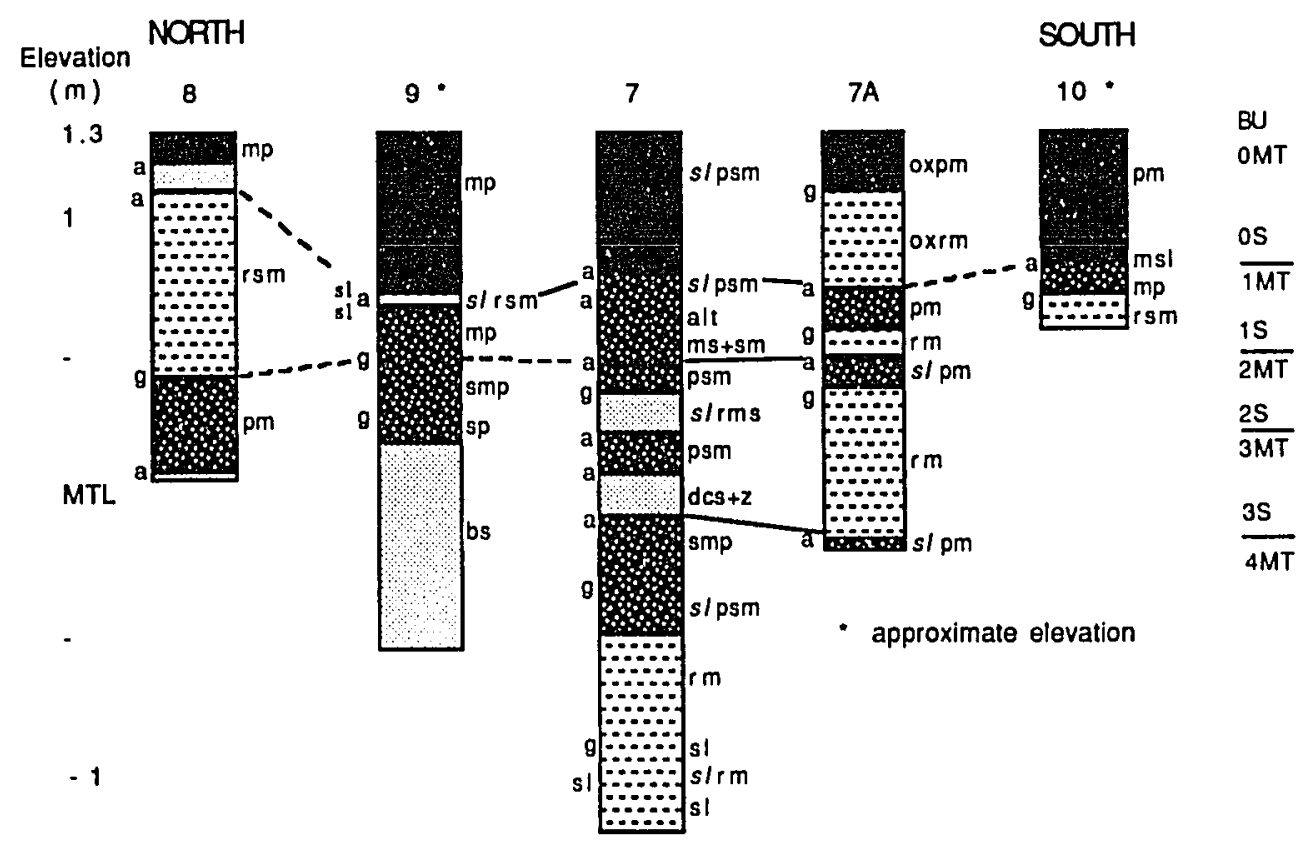

Figure 6. Stratigraphy of additional cores from sites along the length of the Neawanna.

meters depth where penetration was stopped. All contacts between layers at Neawanna $R$ were gradual.

Six burial events were identified in the Neawanna marsh system, but only two sites, Neawanna 2 and 5, recorded them all. The buried peats were found no deeper than $2.6 \mathrm{~m}$. All buried peats (MT), except 4MT at Neawanna 2 and 5 , had abrupt upper contacts with the overlying lower organic sediment (S) and at least $80 \%$ had gradational lower contacts with horizon $S$ below it. The uppermost two buried peats can be traced over a kilometer in cutbank exposures in the upper reaches of the estuary where the best records are found. Tree roots, that protrude from the cutbanks, are often associated with these two buried peat layers. However, only the top two burial events can be traced in cores or cutbanks farther downstream, because of shallow depth of corer penetration owing to thick sand or cobbles and minimal cutbank 


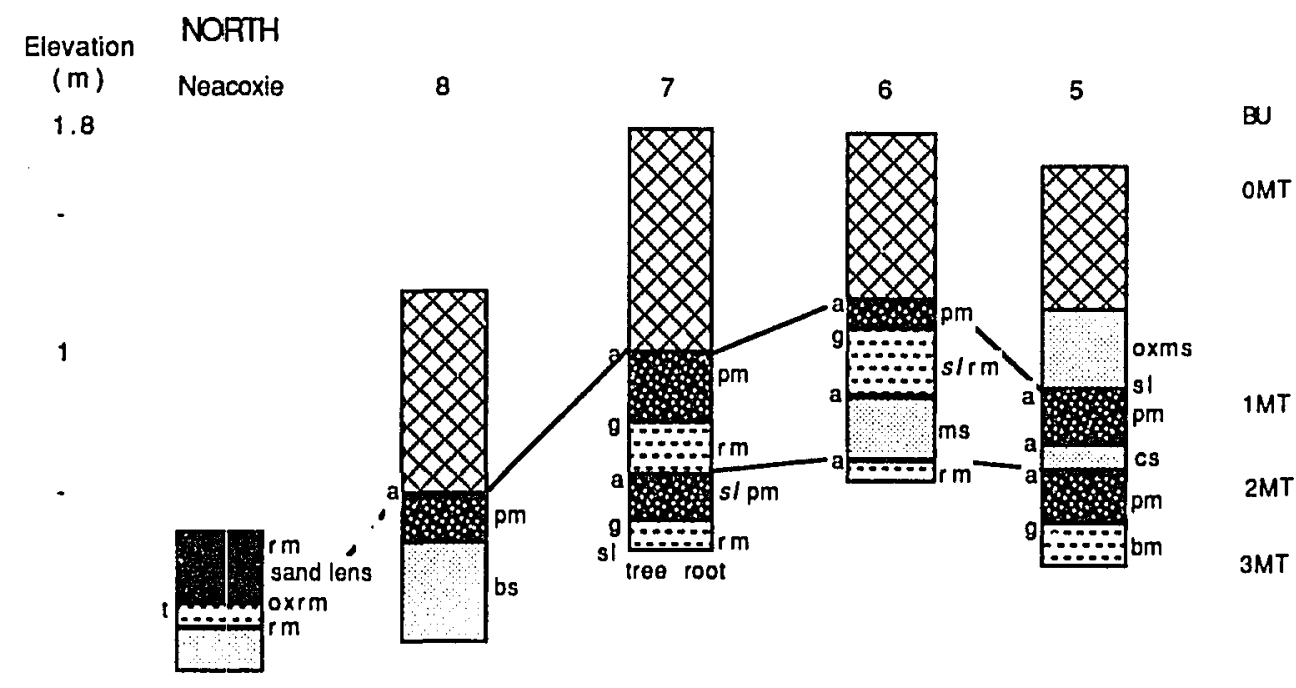

SOUTH

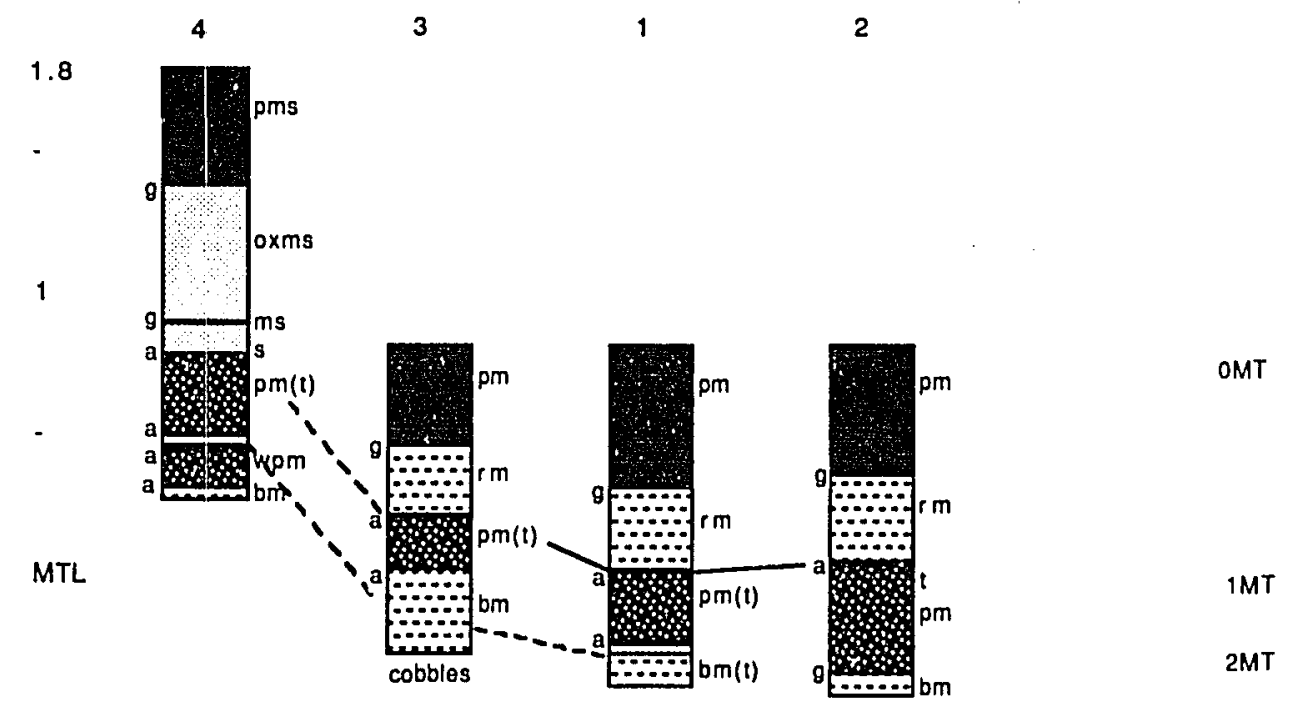

Eigure 7. Stratigraphy of cutbanks along the length of the Neawanna.

exposure. Near the confluence of Neawanna and Neacoxie Creeks, buried tree stumps are exposed at low tide (Neacoxie core site in Figures 4 and 7). The stumps appear to be associated with a weak soil horizon that is overlain by an oxidized mud. In addition, in a sample taken approximately $2 \mathrm{~cm}$ above the tree 
stump the diatom assemblages were predominately freshwater while the samples taken above and below it had predominately brackish/marine diatoms. Triglochin rhizomes were only found in the 15 horizon of Neawanna 2 and were associated with high organic sediments. Distinct SCL's or S's were identified above $1 \mathrm{MT}, 2 \mathrm{MT}, 3 \mathrm{MT}, 5 \mathrm{MT}$ and $6 \mathrm{MT}$, although at not all core sites. The SCL sediments were either 1) sandy mud, muddy sand, or sand, 2) alternating mud and sand laminae/layers (horizon 1S at Neawanna 5 and 7), or 3) weathered and often rounded gravel mixed with woody debris (horizons oS and $2 S$ at Neawanna 2; $3 S$ at Neawanna 7). A weathered gravel layer (1S horizon of CB5) $20-30 \mathrm{~cm}$ thick was also seen in cutbank over a distance of 80 meters downstream of cutbank location 5 (Figure 7). The gravel zone gives way to coarse sand near cutbank 6 .

\section{Laboratony Anallyses}

The grain size, loss on ignition, heavy mineral, and diatom data for all bays in this stucly are summarized in Appendix F. The data are tied to depths below the marsh surface, elevations with respect to mean tide level, and burial unit numbers and horizons. Plots of horizon vs. percent LOI and percent sand will include only the last six events.

Samples from Neawanna 2, 5, and 7 were chosen for analysis. The organic content (percent loss on ignition) decreased from higher values in the MT horizon to lower values in the the overlying SCL and/or S horizons (burial event) in all cores, with a few exceptions at Neawanna 5 (Figures 8-10). The differences in percent organics varied from $<1$ to as much as $28 \%$ (Appendix F). In $80 \%$ of the cases, the organic content increased from the S and/or SCL to the overlying MT. In contrast, the percent sand over the MT to overlying SCL transition increased for all cases (Figures $8-10$ ). In $75 \%$ of the cases, the 
$\%$ LOI Nea 2

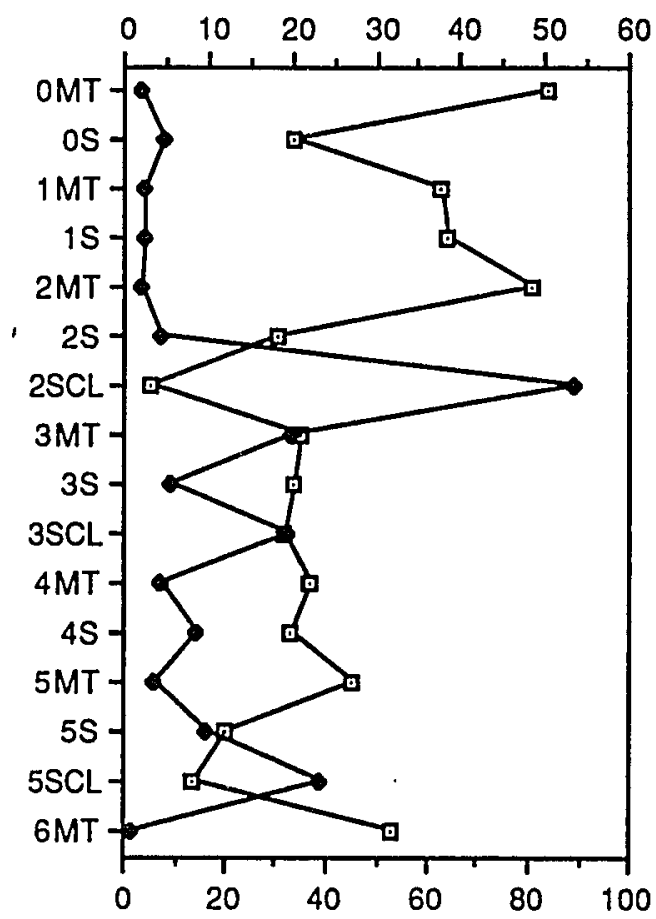

$\%$ Sand Nea 2

Fiqure 8. Plot of burial horizons vs. percent loss on ignition and percent sand for Neawanna 2. Sand = Diamonds; $L O I=$ Squares .

increase was also reflected in the S horizon. $80 \%$ of the transitions from the $S$ or SCL horizon to the overlying MT horizon showed a decrease in sand (exceptions were in Neawanna 2 and 5).

The MT/S/SCL horizons were dominated by freshwater diatom assemblages (see Appendix G). Even at the mouth of the Neawanna there was significant freshwater influence. This is not surprising given the fluvial dominance of the Neawanna estuary. Although, in several instances, there were horizons that had significant brackish and/or marine influence, for 
$\%$ LOINea 5

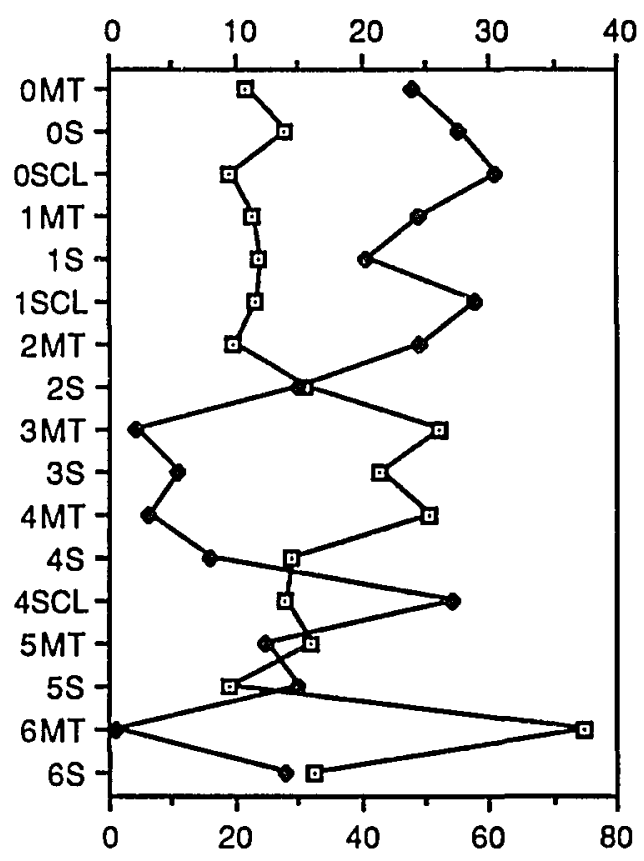

$\%$ Sand Nea 5

Eigure 9. Plot of burial horizons vs. percent loss on ignition and percent sand for Neawanna 5. Sand = Diamonds; LOI = Squares.

example 5MT of Neawanna 5; burial unit $0 \mathrm{~S}$ and $1 \mathrm{~S}$ and 1MT for Neawanna 7. Significant (increase in brackish/marine) changes in diatom assemblages from MT horizons to overlying SCL or S horizons occurred at the following core transitions: 1) Neawanna 2-6MT to 5SCL/S increase in marine diatoms, 2) Neawanna 5-1MT to OS large increase in brackish (e.g., Navicula pusilla) and appearance of marine diatoms, 3MT to $2 S$ increase in brackish and marine diatoms, and 3) Neawanna 7-1MT to OS appearance of marine diatoms, 2MT$1 S$ increase in brackish and marine diatoms, 3MT to $2 S$ minor increase in brackish diatoms. A list of diagnostic diatom species, as well as marsh plant 
$\%$ LOI Nea 7

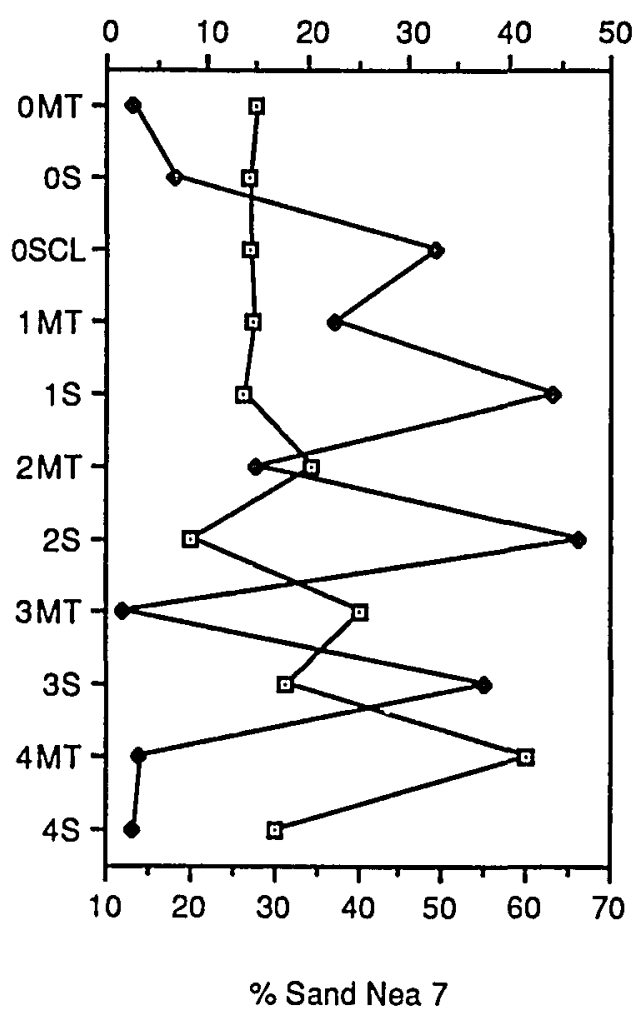

Figure 10. Plot of burial horizons vs. percent loss on ignition and percent sand for Neawanna 7. Sand = Diamonds; LOI = Squares.

species, applicable for all bays is found in Appendix $G$.

If the transition from peat top (MT) to overlying SCL show a increase in percent of beach component, a relative increase, and/or coarsening of the beach sand component or a coarsening of the river sand component, it is considered beach-positive and river-positive, respectively. If no change it is considered neutral, if the trend is reversed it's considered negative, and if there is a mixture of positive and negative it's considered mixed. Significant 
increases in percent beach sand component from several MT to overlying SCL or S horizons were found at Neawanna 2, 5 and 7 (Table I). There is also an increase in the marine sand component from OS $(<20 \%)$ to OSCL $(35 \%)$ at Neawanna 9.

\section{TABLE 1}

PERCENT BEACH SAND IN BURIAL HORIZONS OF THREE CORE SITES IN THE NECANICUM ESTUARY

\begin{tabular}{|c|c|c|c|}
\hline Burial Horizon & Neawanna 2 & Neawanna 5 & Neawanna 7 \\
\hline os & & & 9 \\
\hline OSCL & & 7 & 17 \\
\hline $1 \mathrm{MT}$ & & 11 & \\
\hline 1S & 12 & 7 & 10 \\
\hline $\begin{array}{l}\text { 1SCL } \\
2 \mathrm{MT}\end{array}$ & 0 & $\begin{array}{l}19 \\
7\end{array}$ & \\
\hline $2 S$ & & & 22 \\
\hline $2 S C L$ & 22 & 12 & \\
\hline $\begin{array}{l}3 M T \\
3 S\end{array}$ & 18 & 8 & $\begin{array}{l}8 \\
4\end{array}$ \\
\hline 3SCL & $\begin{array}{l}0 \\
0\end{array}$ & $\begin{array}{l}0 \\
0\end{array}$ & \\
\hline $\begin{array}{l}4 M T \\
4 S\end{array}$ & $\begin{array}{c}0 \\
17\end{array}$ & $\begin{array}{l}0 \\
7\end{array}$ & \\
\hline $\begin{array}{l}4 \mathrm{SCL} \\
5 \mathrm{MT}\end{array}$ & 6 & $\begin{array}{l}15 \\
8\end{array}$ & \\
\hline $5 S$ & 11 & 6 & \\
\hline $\begin{array}{l}\text { 5SCL } \\
6 \mathrm{MT}\end{array}$ & $\begin{array}{c}34 \\
9\end{array}$ & 7 & \\
\hline
\end{tabular}

\section{Radiocarbon Ages}

The ages (all from Neawanna 2) are summarized in Figure 11. Only: 5 out of 6 events were dated. The 4MT horizon was not recovered in the vibracoring operation due to internal rodding. Three additional samples were radiocarbon dated: two peats from the 2(?)MT (RCYBP 680 480 , calibrated range 540-730) and 6MT (2200 \pm 90 and 1979-2359) of Neawanna 5 and charcoal from 2MT $(4.10 \pm 50$ and $316-530)$ of Cutbank 4. The question mark at 2MT is a result of 


\begin{tabular}{|c|c|c|c|c|c|}
\hline $\begin{array}{l}\text { Elevation } \\
\text { (m) } \\
1.5\end{array}$ & $\begin{array}{l}\text { elevation } \\
\text { (m) }\end{array}$ & beta \# & $\begin{array}{c}x \ominus \\
\text { (RCYBP) }\end{array}$ & (cal. $\stackrel{\text { yr BP) }}{\infty}$ & horizon \\
\hline \multirow[t]{2}{*}{1} & 1.02 & 42112 & $480 \pm 60$ & $462-634$ & 1MT \\
\hline & 0.80 & 42113 & $80 C+60$ & $670-903$ & 2MT \\
\hline - & 0.39 & 42088 & $11(10 \pm 70$ & $920-1170$ & 3MT \\
\hline \multicolumn{6}{|l|}{ MTL } \\
\hline & -0.08 & 44595 & $1370 \pm 70$ & $1170-1400$ & 4MT \\
\hline - & -0.40 & & not dated & & 5MT \\
\hline \multirow{2}{*}{-1} & & & & & \\
\hline & -1.18 & 42114 & $20(10 \pm 70$ & $1820-2139$ & $6 \mathrm{MT}$ \\
\hline
\end{tabular}

Eigure 11. Radiocarbon ages of the buried peats from Neawanna 2.

the inability to match the buried peat in the vibracore with its counterpart in the gouge core. Calibrated ages (cal B.P.) are based on studies (Stuiver and Reimer,1986) comparing tree ring and associated radiocarbon ages, in which a radiocarbon age would produce a range of tree ring ages (Figure 11).

\section{NETARTS BAY}

\section{Hydrography and Physiography}

Netarts Bay is approximately $96 \mathrm{~km}$ from the Columbia River (Figures 1 and 12). It is a coastal lagoon bounded by a sand spit to the west, the Coast Range to the east, Cape Meares to the north, and Cape Lookout to the south (Darienzo,1987; Darienzo and Peterson, 1990). The bay is very tidally dominated and has a tidal range of $1.7 \mathrm{~m}$ and tidal prism of $9 \times 10^{6} \mathrm{~m}^{3}$. The bay 


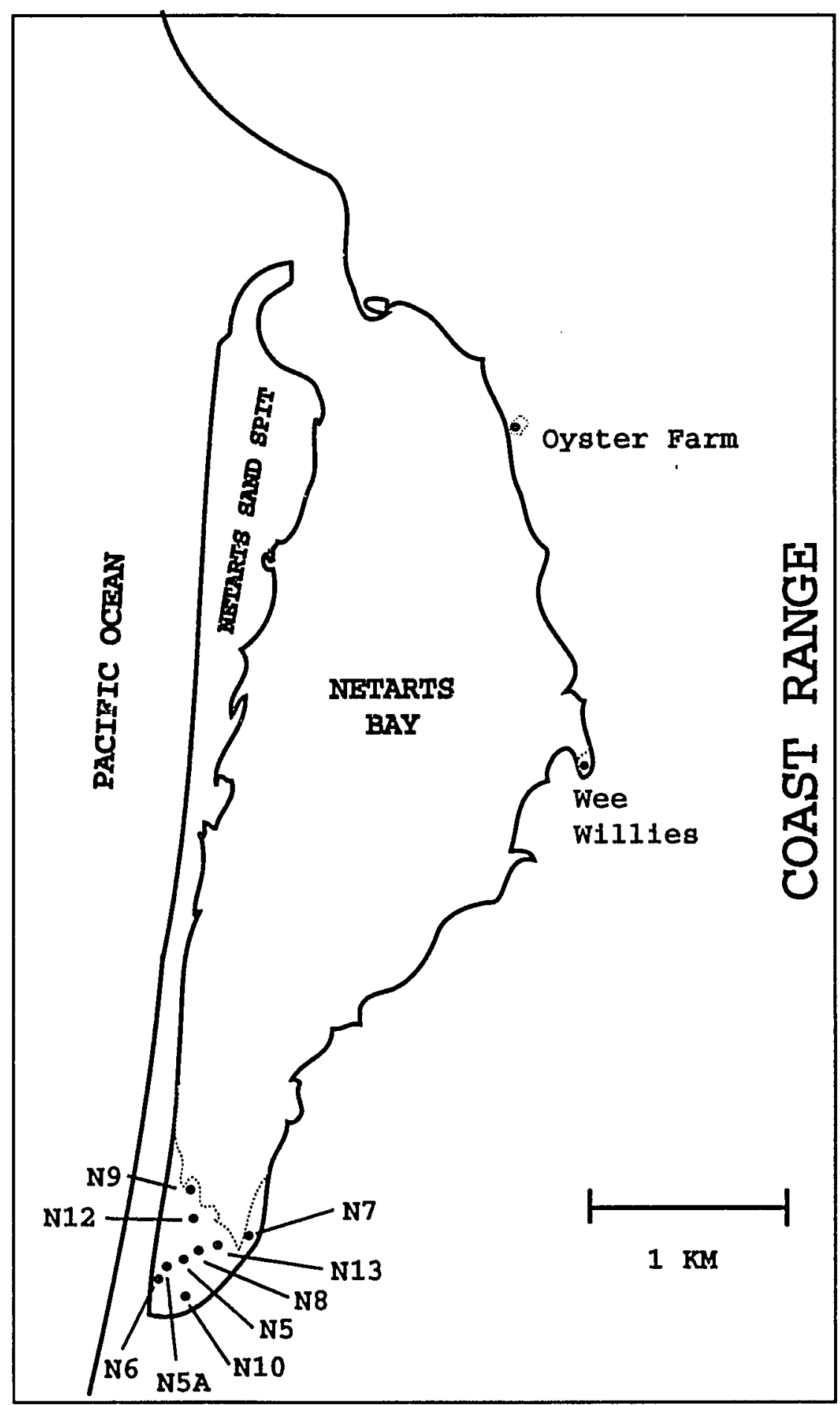

Eigure 12. Netarts Bay general setting and location of salt marsh core sites. 
drains an area of $36 \mathrm{sq} \mathrm{km}$ with an annual freshwater yield of $5.18 \times 10^{7} \mathrm{~m}^{3}$ and an annual sediment influx of 2041 metric tonnes (Percy et al, 1974). Wetlands (mainly high marsh in the southern part of the bay) make up $8.3 \%$ of the estuary (Oregon Department of Land Conservation and Development, 1987).

\section{Core Lecations and Tidal Elevations}

Core locations and tidal elevations are discussed in Darienzo and Peterson (1990)(Figure 12). Four extra gouge cores (N5A, N5, N6, and N7) and one vibracore (N5A) were taken in the main marsh in the southern part of the bay the summer of 1991. N5, N6, and N7 had previously been cored with a vibracore several years ago. One gouge core was taken and cutbank examined in a small pocket marsh near Wee Willie's in the central part of the bay and one gouge core was taken and cutbank examined in a small pocket marsh in the northern part of the bay (Figure 12).

The Wee Willie's site was surveyed to water level and the northern site (Oyster Farm) was tied into both water level and a tidal benchmark $(2.23 \mathrm{~m}$ above MTL) near the boat ramp in the extreme northern part of the bay. The surface of Oyster Farm was estimated to be $0.95 \mathrm{~m}$ above MTL and Wee Willies was estimated to be $0.71 \mathrm{~m}$ above MTL.

\section{Detailed Stratiaraphy}

The stratigraphy is summarized in Figures 13-15. All cores discussed in Darienzo and Peterson (1990) were reexamined and reevaluated because 1) the identification of three more events easily recognized in Oyster Farm, Wee Willies, and N5A cores and 2) the change to the percentage organic classification system used at Alsea Bay (Peterson and Darienzo, 1991). 


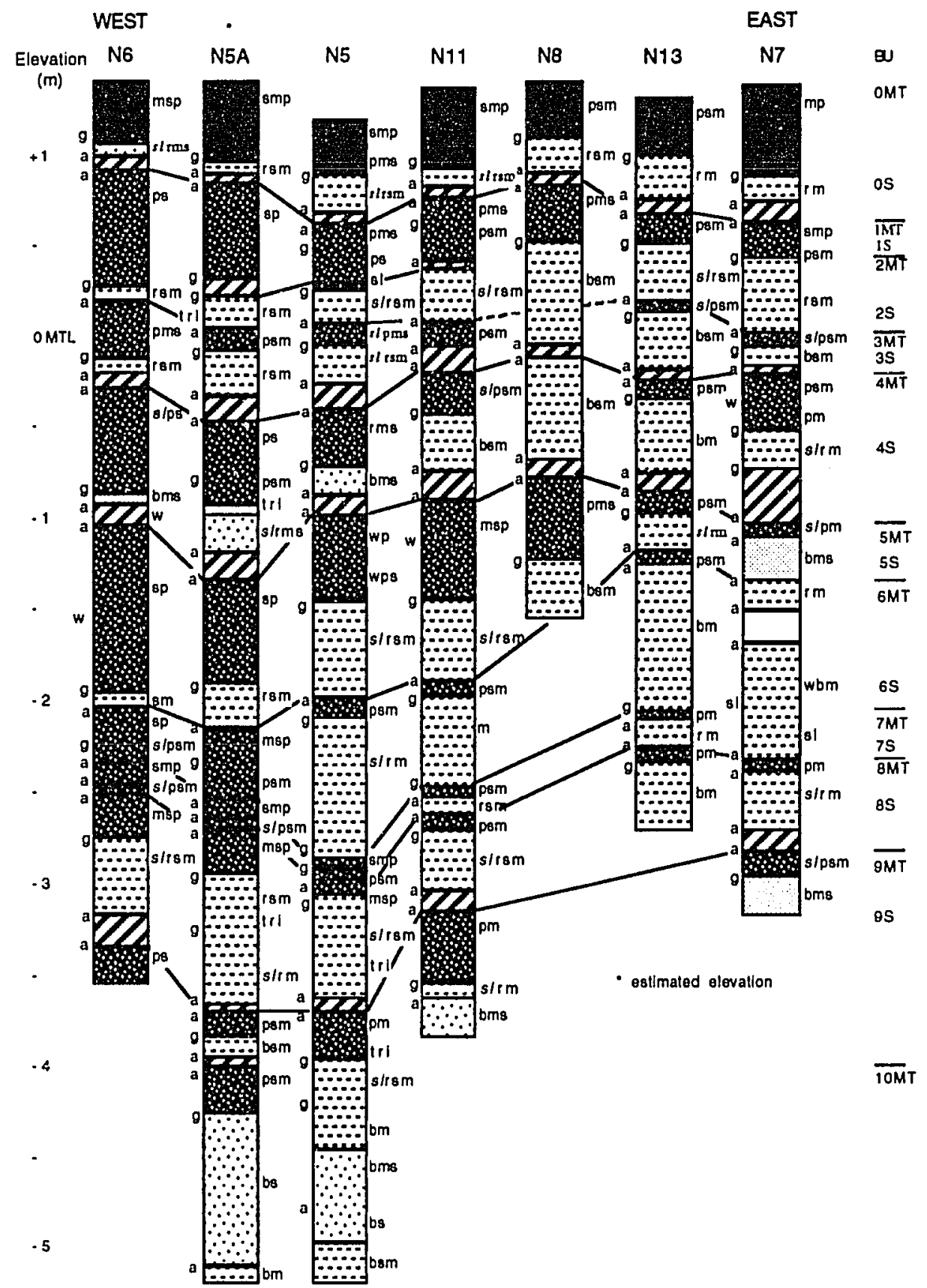

Figure 13. Stratigraphy of Netarts Bay cores from sites on a west to east transect in the southern part of the bay. 


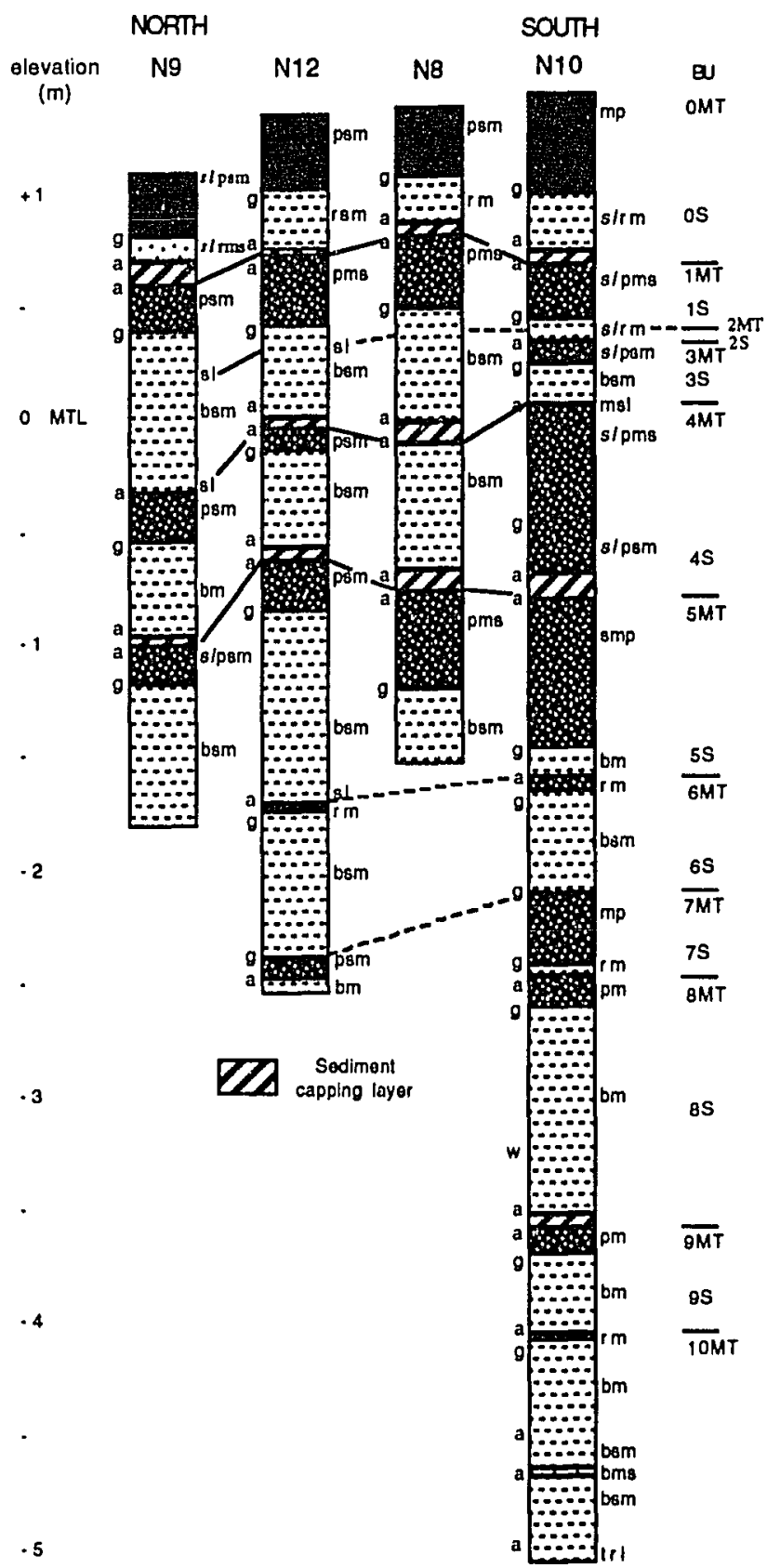

Eigure 14. Stratigraphy of Netarts Bay cores from sites on a north to south transect in the southern part of the bay.

However, the 7MT to 6 S transition was not noted at Oyster Farm or at N7. As a result, the siratigraphy was adjusted to reflect those changes. A total of 10 


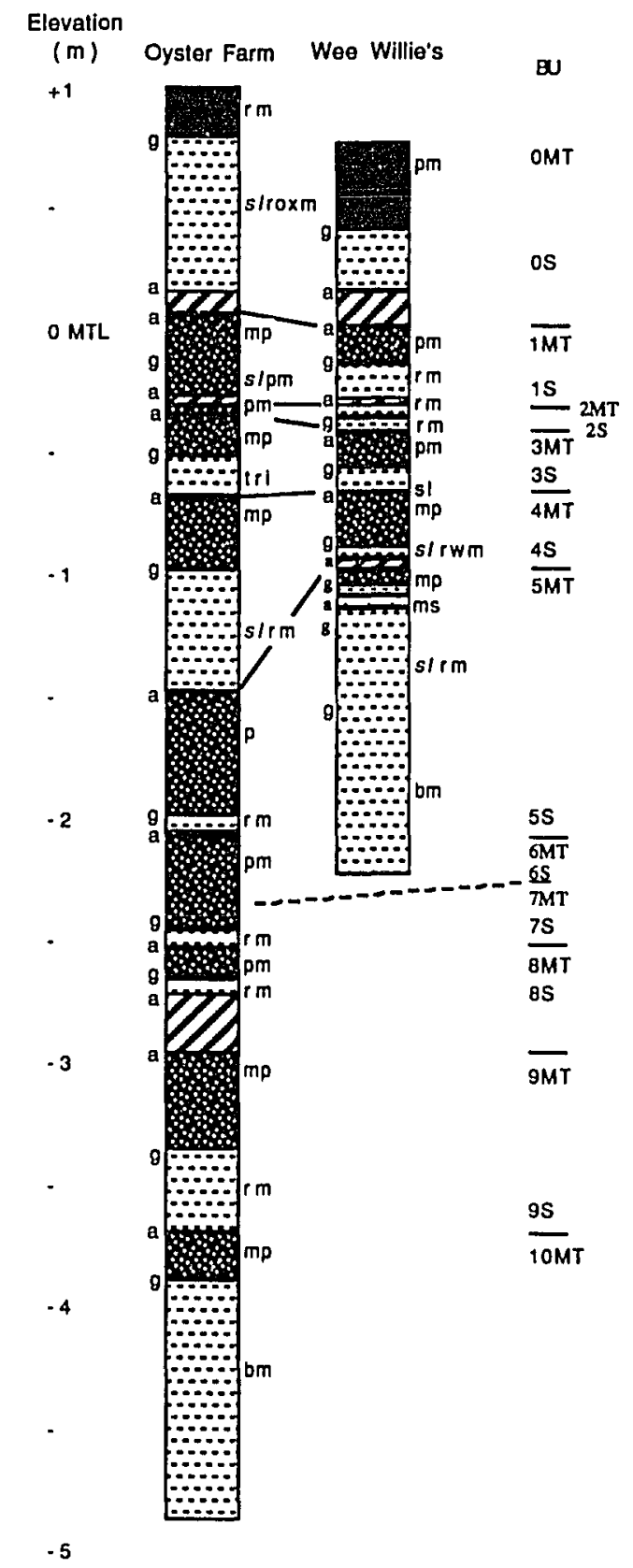

Fiqure 15. Stratigraphy of the cores from sites in the central and northern part of Netarts Bay.

burial events above a depth of $5.5 \mathrm{~m}(-4.0 \mathrm{~m} \mathrm{MTL})$ below the marsh surface were identified at Netarts. The events in all parts of the bay were correlatable 
based on 1) the number of events 2) presence or absence of sediment capping layers, 3) degree of peat development "and 4) diatoms. The extra events were 2MT, 6MT, and 10MT. Although recognizable at Oyster Farm and Wee Willies, 2MT was barely discernable in the southern marsh (Figures 13 and 14). At I Oyster Farm and Wee Willies, the buried peat and rooted mud, respectively, are characterized by an abrupt contact with overlying sand (1SCL) and a gradual contact with underlying lower organic sediments (2S)(Figure 15). In contrast, $6 \mathrm{MT}$ is easily recognizable in several core sites (N5, N10,N11, N12, N13, and possibly N7) as well as Oyster Farm and N5A. The buried peat is abruptly overlain by barren or rooted muds ( $5 \mathrm{~S}$ horizon) at all sites and by a $5 \mathrm{SCL}$ horizon at Oyster Farm and N7. Event, 10MT is easily recognizable, but was only identified at N5A and N10. It is characterized at N5A by an abrupt contact with overlying sand (9SCL) (and lower organic sediments above the sand-9S) and a gradual contact with underlying lower organic sediments (10S) below it. In addition, at N5A Triglochin rhizomes were found above 3MT within rooted sandy mud and at the transition between $4 S$ and $4 M T$ within peaty mud. At N5, depth adjustments for the burial units were made based on the gouge core stratigraphy and at N6 depth adjustments were made and other horizons added from a recent gouge core. N7 stratigraphy was changed considerably below the -0.5 MTL based on the data from the gouge core. The differences in N7 stratigraphy between the gouge core and the original vibracore are probably due to rodding in the second and deeper section of the vibracore. The inside diameter of the deeper section was two inches compared to three inches for the shallower section. Rodding problems tend to increase with decreasing diameter (Smith, 1987). Finally, the 6MT-10MT horizons tended to be higher in elevation at the sites (Oyster Farm, N7, and N13) on the eastern side of the bay. 
This is possible because the Holocene estuarine deposits below the lowest buried peat at these sites overly the Pleistocene platform at a shallower depth and as a result the sediments have not settled as much as the sites to the west over the long term. This draping phenomenon of codepositional layers is also seen elsewhere in other Pacific Northwest estuaries (Grant, personal communication, 1991).

\section{Laboratory analyses}

The majority of the lab analyses are reported in Darienzo (1987) and Darienzo and Peterson (1990). Additional samples were analyzed for loss on ignition, grain size, diatom, and heavy minerals (Appendix F). Samples for LOI, grain sizes, diatoms, and heavy minerals, from Wee Willies and Oyster Farm, were taken to document the new burial event (2MT and 1SCL horizon), determine sand sources for other events and to improve the descriptive stratigraphy. LOI samples were taken from the N7 and N5A gouge cores to improve the stratigraphic description and document the $6 \mathrm{MT}$ to $5 \mathrm{~S}$ transition. Samples from N10 and N7 were analyzed for heavy minerals. Samples for diatom analysis came from N12, N5A, and N7.

There was a decrease in organic content from $2 M T$ to $1 S$ and $3 M T$ to $2 S$ at both Wee Willies and Oyster Farm and from 6MT to 5S at N7 and N5A (Appendix $F$ and Figure 15). Diatom assemblages from the 8MT horizon at N7 were mainly freshwater with a minor brackish component and brackish/marine from 7S, whereas from 7MT and 7S at N12 the diatoms were brackish/marine. The diatom assemblages from 7MT, 7S, 8MT of Oyster farm were all freshwater. At other sites in the southern marsh where 7MT, 7S, and 8MT are identified, the diatom assemblages are freshwater. The diatom assemblage over the 6MT/5S 
transition at N5A changed from a mix of freshwater and brackish to brackish/marine (Appendix F).

The results of heavy mineral analyses from cores N7, N10, Oyster Farm and Wee Willies are summarized in Table II. All samples contained mostly beach sand $(93-100 \%)$, except the OSCL horizon of N10 which had only $16 \%$. Samples that had a non-beach sand component also had a silt component that tended to be angular and weathered. Four out of five of these non-beach samples came from the sediment capping layer. A negative-beach transition is recorded in N10 for the 1MTOSCL and 3MT/2SCL events and a positive-beach in N10 for 4MT/3SCL. In contrast, samples from core N7 had $100 \%$ beach sand, but many contained a silt component.

\section{Radiocarbon Ages}

All events were dated and the ages summarized in Figure 16 and discussed in Darienzo and Peterson (1990). Additional buried peats (2MT from Oyster Farm cutbank and 6MT, 9MT, and 10MT from N5A vibracore) were dated and are included in Figure 16. Not included in Figure 16 are radiocarbon ages from the Oyster Farm cutbank of the $3 S$ horizon (1480 \pm 60 RCYBP, Trigldichin rhizomes 5-15 cm above 4MT) and 5MT horizon (1820 $460 \mathrm{RCYBP}$, piece of in situ Spruce stump). The 5MT age at Oyster Farm is similar to the 5MT age from the southern part of the bay $(1840 \pm 60)$ supporting a system-wide, and therefore a coseismic, burial event. The rhizome age constrains the age of the 4MT coseismic burial event between 1480 (growth of Triglochin) and 1670 years B.P (the age of the top of the paleo-high marsh). Horizons 7MT and 8MT at N5A were dated, because the correlatable units in N5 had reversed ages. The ages from the 7MT $(3150 \pm 80)$ and $8 M T(2860 \pm 70)$ horizons at N5A were similar to those from N5. 
TABLE \|

PERCENT BEACH SAND IN BURIAL HORIZONS OF CORE SITES IN NETARTS BAY

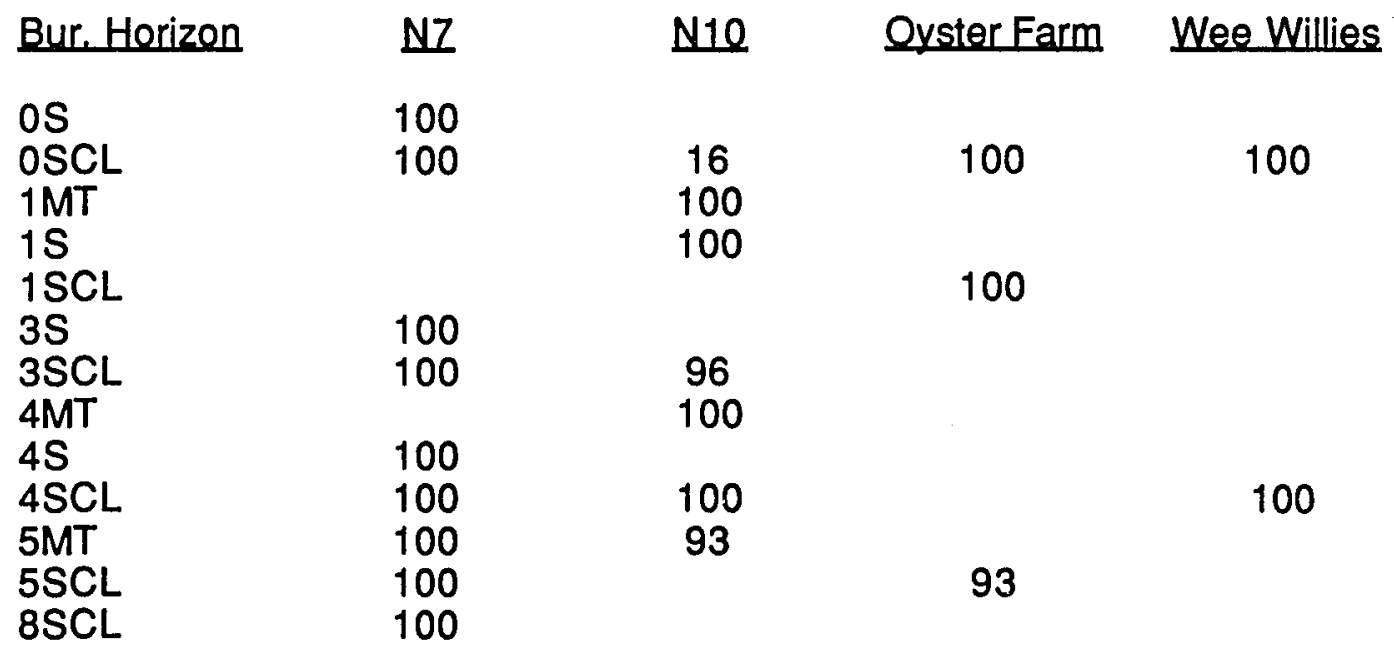

NESTUCCA BAY

Hydroaraphy and Physiegraphy

Nestucca Bay lies approximately $121 \mathrm{~km}$ south of the Columbia River and is bounded on the west by a sand spit and on the east by the Coast Range (Figures 1 and 17). The bay is separated into two sections by Cannery Hill. Major tributaries are the Nestucca River, which occupies a large valley, and the Little Nestucca River. The drainage is made up of mainly Tertiary volcanic rocks (basalt) and estuarine and marine sedimentary rocks, such as tuffaceous shales and siltstones and feldspathic/micaceous sandstones and siltstones (Baldwin, 1981). The Nestucca River is $85 \mathrm{~km}$ long and the Little Nestucca is $31 \mathrm{~km}$ long with the heads of tide at river kilometer 11.3 and 3.7, respectively. The riverdominated estuary drains an area of $834 \mathrm{sq} . \mathrm{km}$ ( $80 \%$ of which is the Nestucca River drainage) with an average annual freshwater yield of $1.97 \times 10^{9}$ cubic meters ( $70 \%$ from the Nestucca River). The mean tide range is 1.76 meters. 


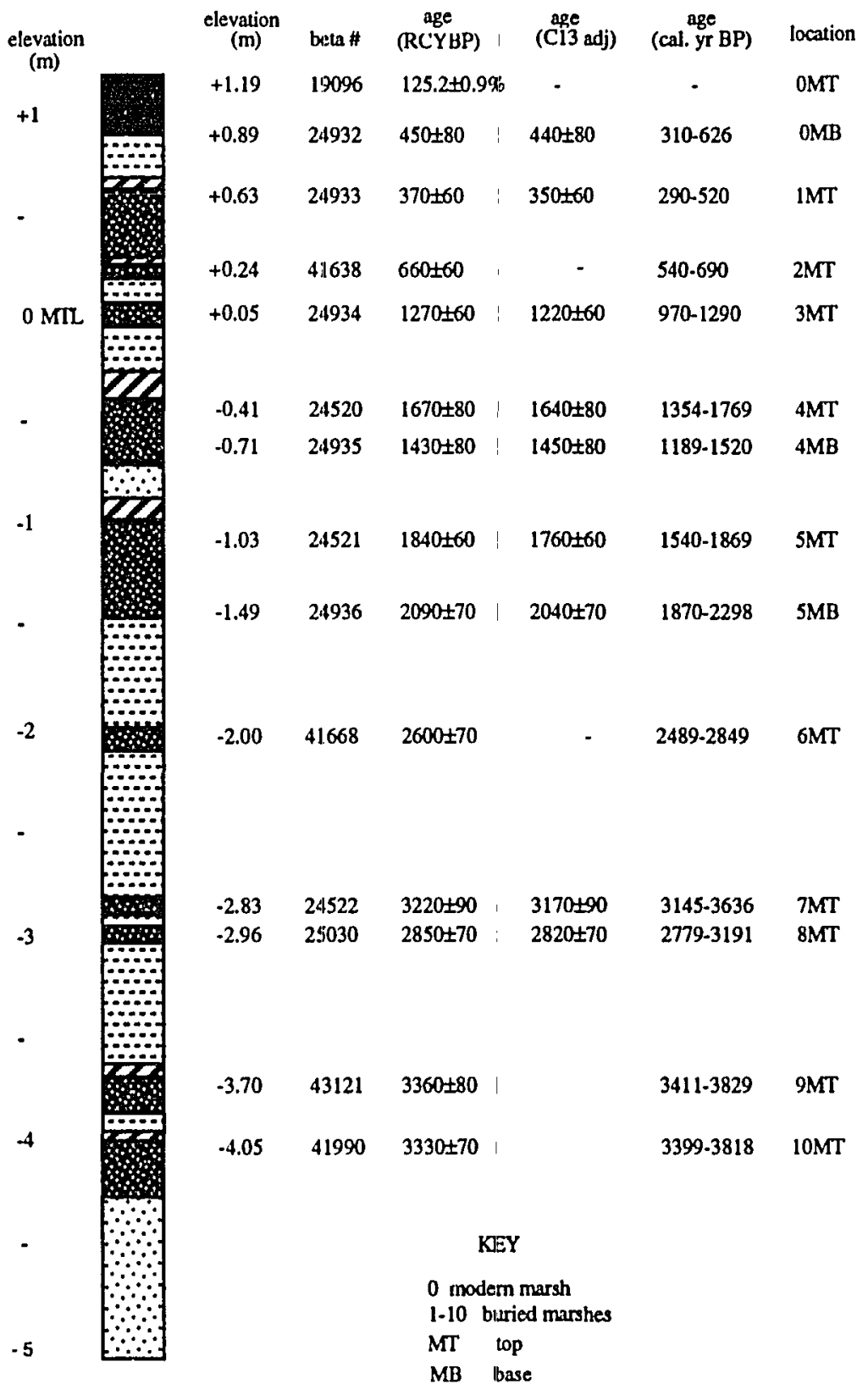

Eiqure 16. Radiocarbon ages of buried peats in Netarts Bay.

The rivers deposit 49,000 metric tonnes of sediment per year into the bay (Percy et al, 1974). Wetlands (salt marsh) make up approximately $17.4 \%$ of the estuary with most of the wetland being high salt marsh (71\%) (Oregon Department of 


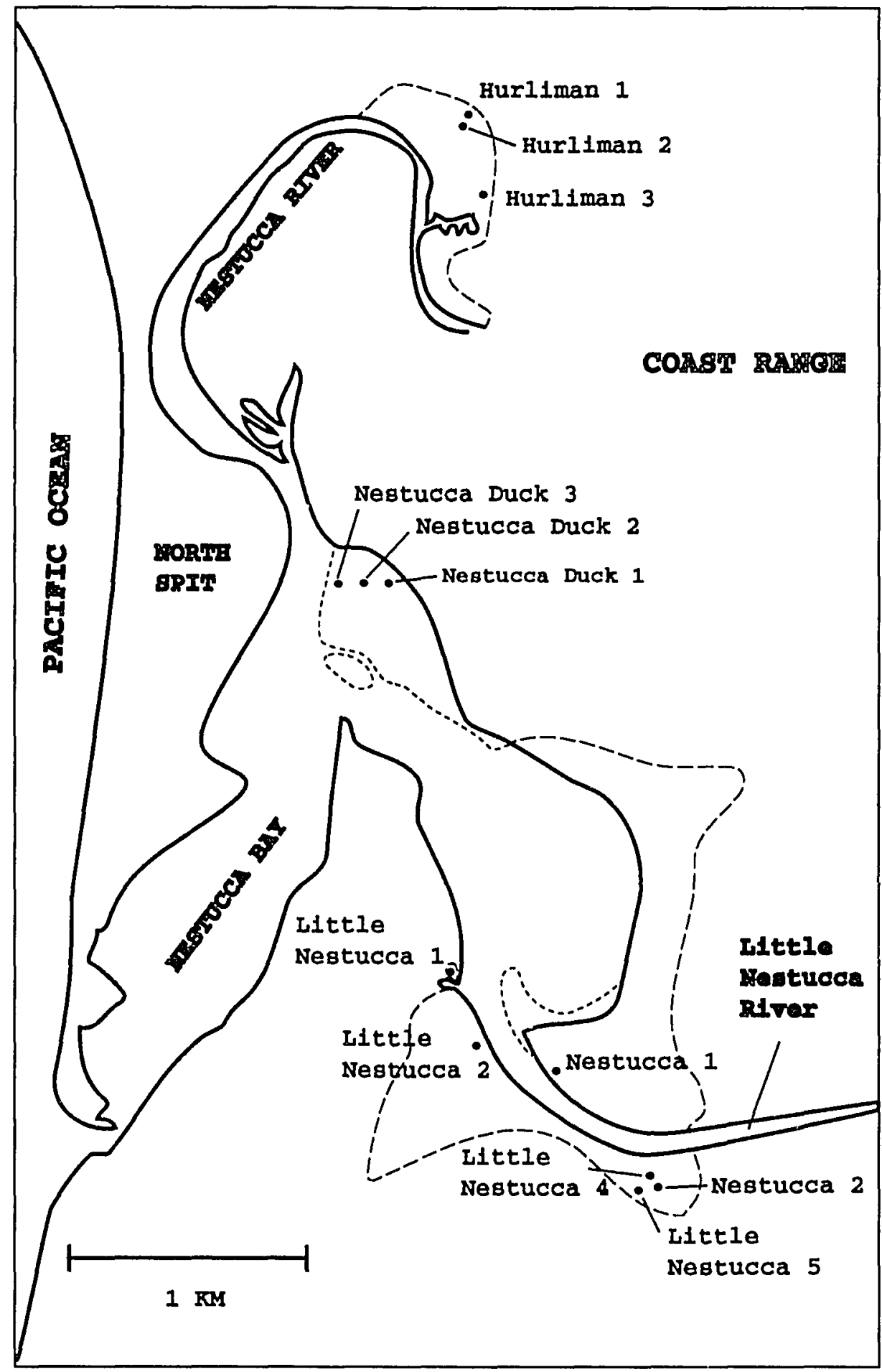

Figure 17. General setting and core site locations of Nestucca Bay on marsh (short dashes) or pastureland (long dashes). 
Land Conservation and Development, 1987). In the past, wetlands were more extensive, but due to diking and creation of pasture land, they have decreased.

\section{Core Locations and Tidal Elevations}

Three locations were cored on diked pasture land adjacent to the Nestucca River east of the town of Woods, three locations were cored in marsh opposite the widest part of the Nestucca Spit, and six locations were cored on diked pasture land adjacent to the Little Nestucca River (Figure 17). A vibracore was taken at the Nestucca Duck 1 site. Engine-powered vibracores were taken at Hurliman 2 and Little Nestucca 5, however rodding was a problem especially at Hurliman 2. Open stem auger cores were taken at these sites. Although rodding was still a problem at Hurliman 2, we were able to recover all except one meter of the $13.5 \mathrm{~m}$ cored. This core contains the longest record of buried peats in the Pacific Northwest. The Little Nestucca core encountered bedrock at a depth of $7.5 \mathrm{~m}$, whereas the Hurliman 2 core did not. Cutbanks were examined but were considered suspect owing to diking and slumping. Other marsh and pasture sites were cored, e.g. on the bay side of the spit and upriver of the Nestucca sites, but no buried peats were identified so they are not included.

Since no tide gauges were ever established in Nestucca Bay, all core sites were tied into water level and sites Little Nestucca 4 and 5 were tied into a benchmark located on the 101 bridge crossing the Little Nestucca River. These data were then compared to tidal data in adjacent bays and tidal elevations for the water levels and core sites were estimated. Modern tide flat and marsh locations were tied into water levels along the east bank of the Little Nestucca River north of the 101 bridge. Tidal data is summarized in Appendix D. 
Detailed Stratigraphy

Stratigraphy is shown in Figures 18-20. Burial events are located in various parts of the Nestucca system. A total of 12 burial events at a maximum depth of $11 \mathrm{~m}$ were identified in Nestucca Bay. Ten of the events were recognized along both the Nestucca and Little Nestucca Rivers to depths of 10 and $7 \mathrm{~m}$ below the pasture surface at Hurliman 2 and Little Nestucca 5 , respectively. The individual buried peats for each event are at roughly similar depths at both sites until the 6th event. For example, the 2MT horizon at Hurliman 2 and at Little Nestucca 5 is at approximately $0.75 \mathrm{~m}$ depth for each site. Below 5MT the Hurliman 2 equivalent horizons (based on radiocarbon ages) are 1-3 $\mathrm{m}$ lower than Little Nestucca 5, perhaps from long-term settling due to thicker Holocene deposits over bedrock at Hurliman 2 than at Little Nestucca 5. The last event (1MT) might have been only identified at the Nestucca Duck sites based on radiocarbon age (400 RCYBP). The youngest age of the uppermost event at Little Nestucca 5 and Hurliman 2 was 940 RCYBP from the 1MT horizon. However, it will be assumed that the topmost event at Hurliman and Little Nestucca will be considered correlative with Nestucca Duck 1MT, because the number and depth of the last 6 events in Little Nestucca 5 are the same at Netarts Bay to the north and Siletz Bay to the south.

All buried peats had abrupt upper contacts with overlying lower organic sediments (S) or sediment capping layers (SCL) with very few exceptions (e.g. 6MT at Hurliman 2 and 4MT at Little Nestucca 5 and Nestucca 2) and approximately $76 \%$ had gradual lower contacts with the $S$ horizon. Distinct SCL's are not common and are confined to cores along the Little Nestucca River or across from the wide part of the Nestucca spit at Nestucca Duck. For example, they're located above 1MT (barren muddy sand layers) in the three 


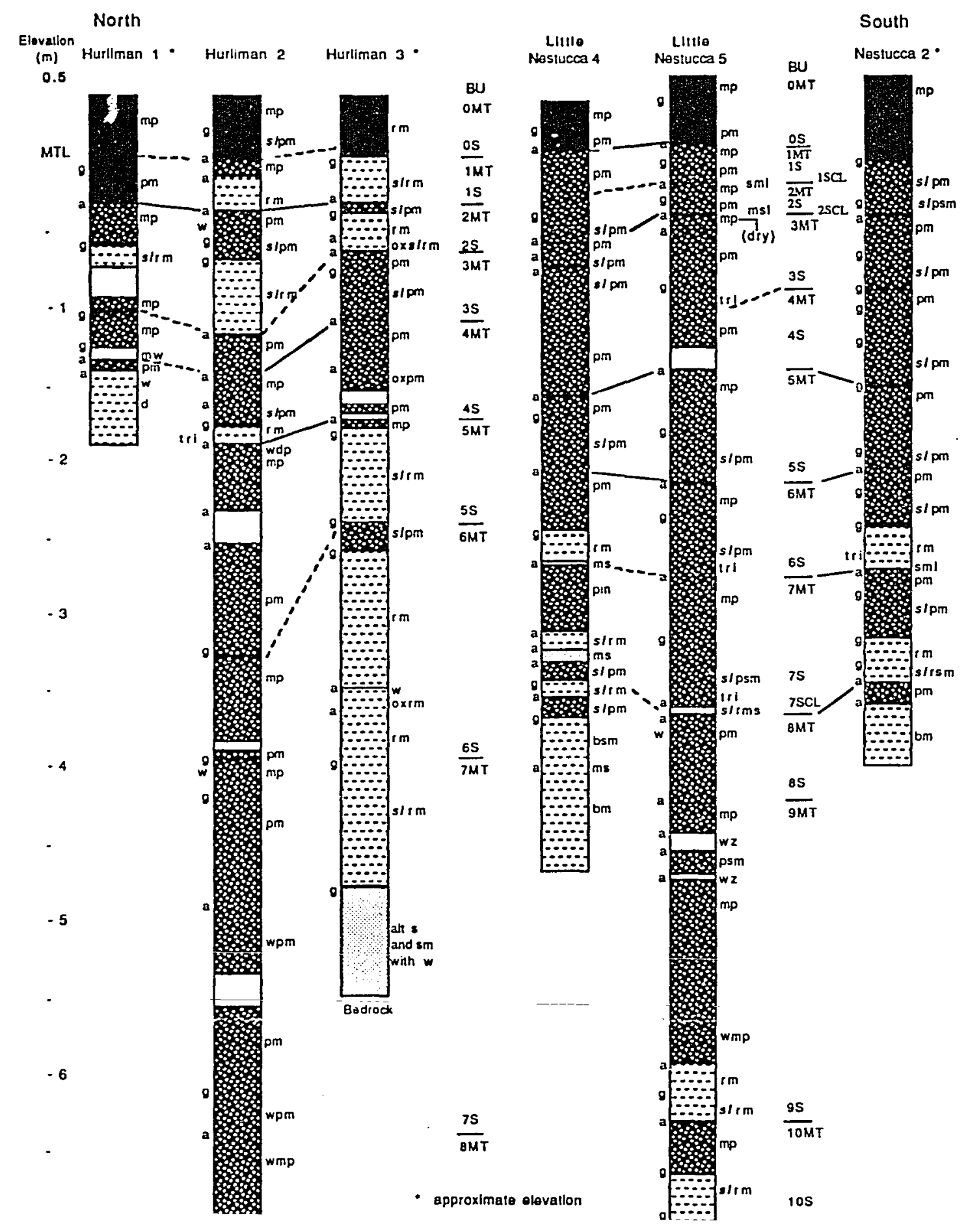


. 


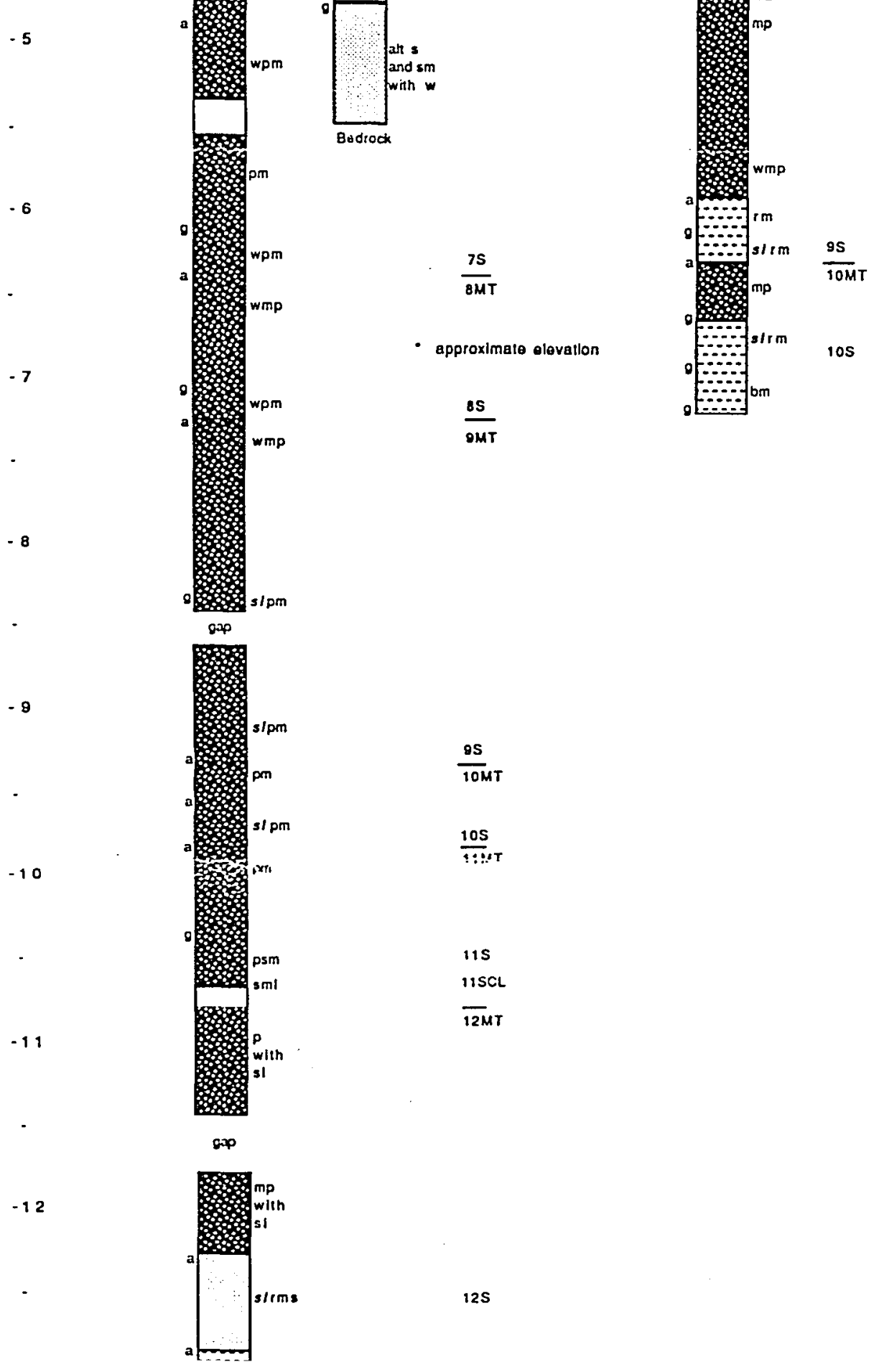





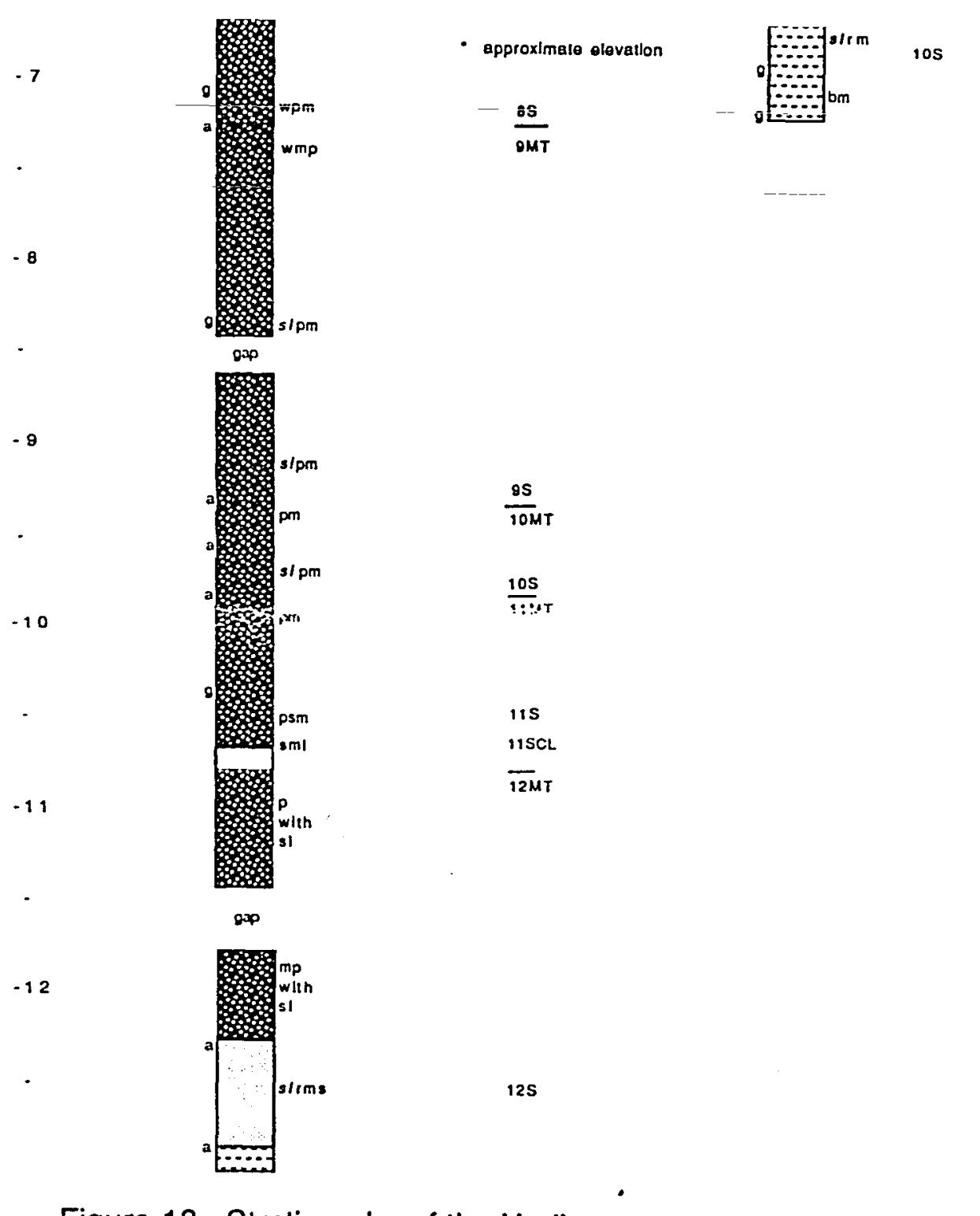

Eigure 18. Stratigraphy of the Hurliman and Little Nestucca cores. 
. 


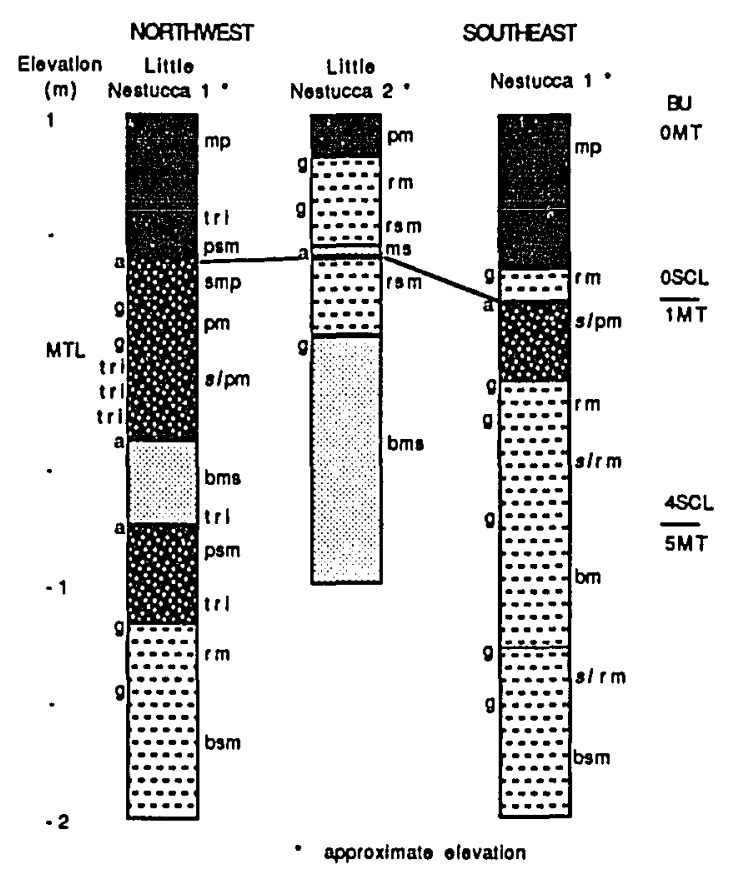

Figure 19. Stratigraphy of additional cores from sites in the lower reaches of the Little Nestucca River.

Nestucca Duck cores, above 2MT (sandy mud laminae), 3MT (muddy sand laminae), and 8MT (muddy sand layer) in Little Nestucca 5, above 3MT (sandy mud layer), 7MT (sandy mud laminae) and 8MT (sandy mud layer) in Nestucca 2, 7MT and 8MT (muddy sand layers) in Little Nestucca 4, above 1MT (muddy sand) and 5MT (muddy sand) in Nestucca 1, and above 1MT (muddy sand) in Little Nestucca 2. Triglochin rhizomes were identified above 5MT within rooted mud at Hurliman 2, above 4MT,7MT and 8MT within peaty to slightly peaty mud, above $7 \mathrm{MT}$ within rooted mud at Nestucca 2, above $1 \mathrm{MT}$ and 5MT within peaty mud and rooted muddy sand, respectively, at Little Nestucca 1, and finally above 1MT within rooted sandy mud at Nestucca Duck 2. 


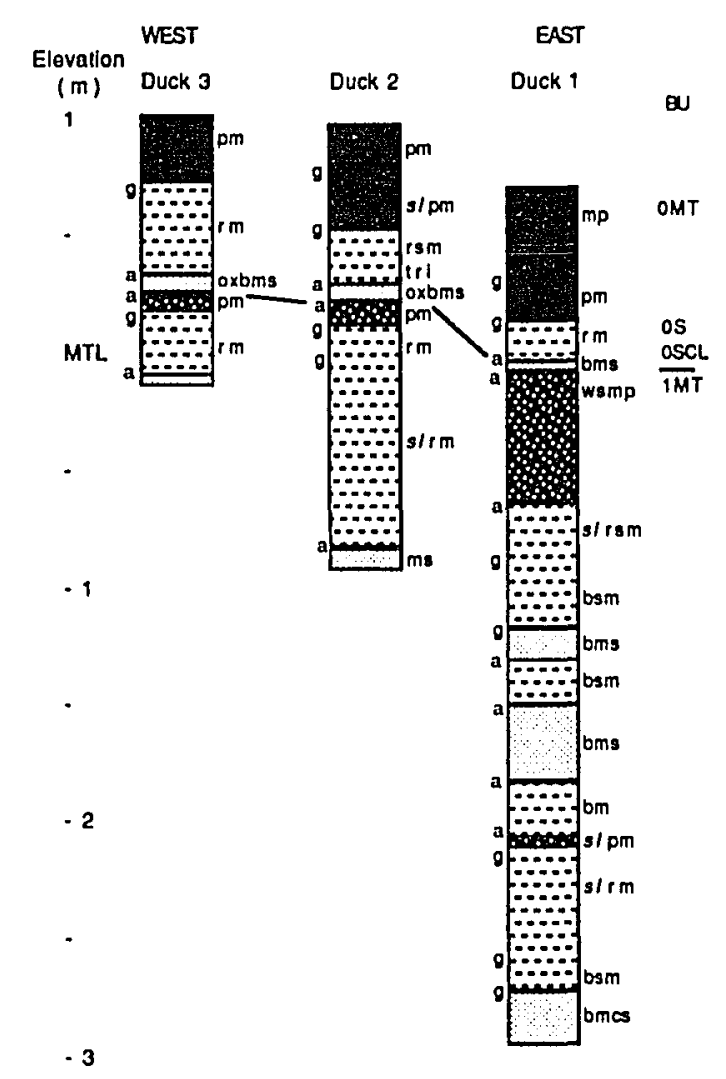

Figure 20. Stratigraphy of the Nestucca Duck cores across from the North Spit.

\section{Laboratory analyses}

The main cores selected for detailed analysis were Hurliman 2 and Little Nestucca 5. Selected samples from Nestucca Duck 1-3, Nestucca 2, Hurliman 1 and 3, and Little Nestucca 1, 2 and 4 were also taken. Laboratory results are summarized in Appendix F. All MT to overlying S/SCL transitions showed a decrease in organic content and, with only two exceptions, there was an increase in organic content from S/SCL horizons to overlying MT horizons (Figures 21-22). There was a significant increase in percent sand from the MT to overlying SCL horizon in a few transitions, e.g. Nestucca Duck sites (Figure 20, Appendix F). However, most transitions either showed an insignificant 
increase in percent sand $(\leq 6 \%)$ or a decrease (Figures 21-22). Occasionally there was a significant change in diatom assemblages from MT to overlying S/SCL horizons (Appendix F). For example, in Little Nestucca 5, there was a change from a freshwater/brackish-marine mix to exclusively brackish-marine from $5 \mathrm{MT}$ to $4 \mathrm{~S}$ and from 10MT to $9 \mathrm{~S}$. At Hurliman 2, there was a change from freshwater to brackish-marine from $5 \mathrm{MT}$ to $5 \mathrm{~S}$ and a change from freshwaterdominant/brackish-marine mix to brackish-marine-dominant/freshwater mix from 9MT to $8 \mathrm{~S}$ and $12 \mathrm{MT}$ to $11 \mathrm{~S}$. In addition, there appears to be a gradual change within the buried peat of burial unit 9 in Little Nestucca 5 from freshwater dominance at the base to brackish-marine dominance at the top.

Heavy minerals analyses were completed for the Nestucca Duck sites, Little Nestucca 1, 2, 4, and 5, and Nestucca 2 (Table III). The transitions from $1 \mathrm{MT}$ to OSCL were determined to be positive at Nestucca Duck 1 and 3 with a decrease in percent sand and beach sand component landward from site 3 to 1 , whereas the transition from 1MT to 0SCL at Nestucca Duck 2 was reversed. There were also positive transitions in a few horizons in the other cores. Nestucca Duck 3, the site closest to the bay, went from river with minor beach $(1 \mathrm{MT})$ to coarse beach with minor river $(O S C L)$ to coarse river with trace beach (OS). The transitions from MT to overlying SCL or S horizon at the other sites were either positive or neutral, with the positive transitions either coarsening beach sand (Little Nestucca 1), coarsening river sand (Little Nestucca 2 and 5), a very minor increase in beach sand (Little Nestucca 4 and 5) or a major increase in beach sand (Little Nestucca 5-10MT to 9S, Little Nestucca 2-1MT to OSCL). 
$\%$ LOI LNeS 5

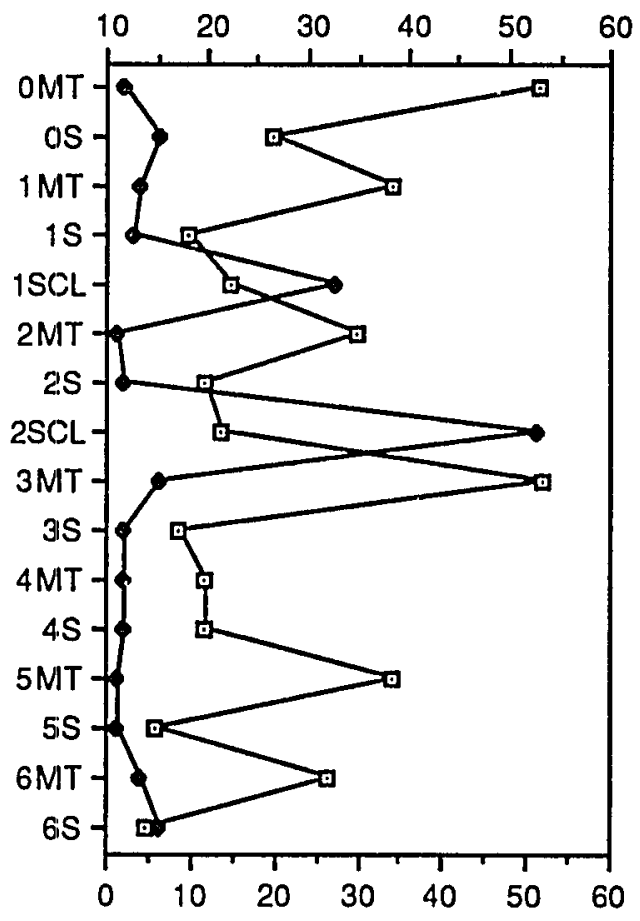

$\%$ Sand LNes 5

Eiqure 21. Plot of burial horizoris vs. percent loss on ignition and percent sand for Little Nestucca 5. Sand = Diamonds; LOI = squares.

\section{Radiocarbon Ages}

Almost all samples (peats and one wood fragment) for radiocarbon age determinations were taken from the drill or vibracores of Little Nestucca 5 and Hurliman 2 (Figures 23 and 24). All events at Little Nestucca were dated. Not all events were dated at Hurliman 2, however, because of collection problems with both the vibracore and drill core in the top 2 meters. Also collected and dated was a piece of wood at $45 \mathrm{~cm}$ depth in the starter hole for the Hurliman 2 vibracore and peat from the $1 \mathrm{MT}$ horizon of Nestucca Duck 1. An age was 
$\%$ LOI Hur

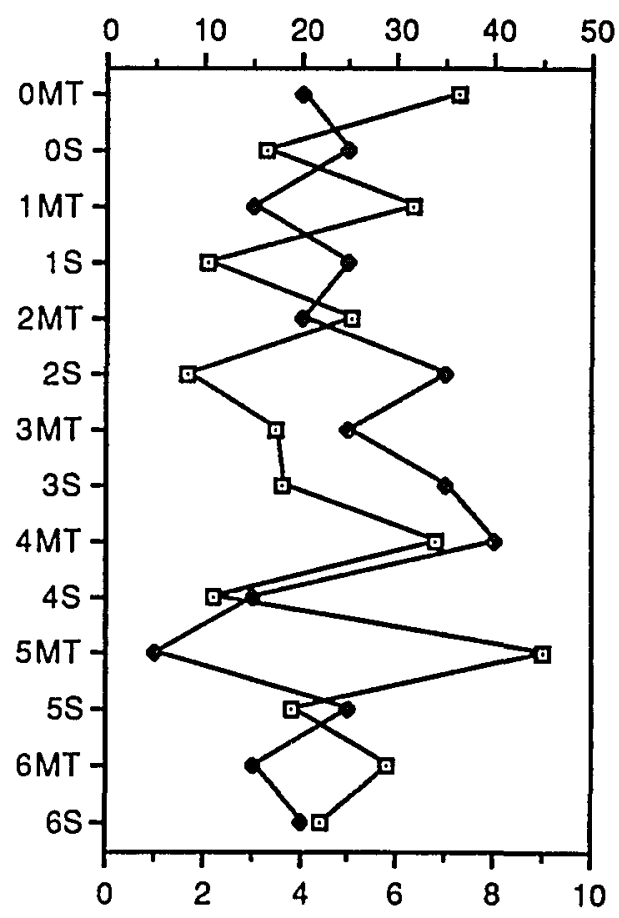

$\%$ Sand Hur 2

Figure 22. Plot of burial horizons vs. percent loss on ignition and percent sand for Hurliman 2. Sand = Diamonds; $L O I=$ squares.

determined for the Nestucca Duck sample, because no ages from the other cores were less than 1460 years B.P. Although the wood sample from the Hurliman 2 starter hole was 940 years B.P.,a wood sample from a similar depth $(53 \mathrm{~cm})$ in the drill core gave an age of 1760 years B.P. Nick Hurliman, the owner of the pasture where the drill core was taken, mentioned that the pasture was forested in the late 19th or early 20th century and the wood used for dating a burial event in the top $50 \mathrm{~cm}$ is suspect. Apparently, the last event recorded at Nestucca Duck was either not recorded at Little Nestucca and Hurliman or the ages are not correct. The ages from the eastern sites in Nestucca could be 
TABLE III

PERCENT BEACH SAND IN BURIAL HORIZONS OF CORE SITES IN NESTUCCA BAY

Burial Horizon Nestucca Duck 1 Nestucca Duck 2 Nestucca Duck 3

$\begin{array}{llll}\text { OS } & 1 & 4 & 5 \\ \text { OSCL } & 38 & 13 & 76 \\ \text { IMT } & 9 & 59 & <20\end{array}$

\begin{tabular}{cccc} 
Burial Horizon & Little Nestucca 1 & Little Nestucca 2 & Little Nestucca 5 \\
\cline { 1 - 1 } OSCL & 1 & 7 & \\
1MT & 8 & 1 & \\
4SCL & 20 & & \\
5MT & 2 & & 1 \\
$7 S$ & & & 8 \\
$7 S C L$ & & & 0 \\
8MT & & & 16 \\
$9 S$ & & & 5 \\
10MT & & &
\end{tabular}

$\begin{array}{ccc}\text { Burial Horizen } & \text { Little Nestucca 4 } & \text { Nestucca 2 } \\ \text { 2SCL } & & \\ \text { 3MT } & & 4 \\ \text { 7SCL } & 2 & 0 \\ \text { 8MT } & 1 & \end{array}$

suspect, because marshes in bays to the north (Netarts) and south (Siletz) of Nestucca also recorded 3 events in the top meter within the last 1400 years (Figure 16). However, the lower elevation of the uppermost buried peat at Hurliman and Little Nestucca with respect to Nestucca Duck's might indicate that the events were not recorded, although the lower elevation may be due to dropping of the pasture elevation after diking due to grazing and drying. Nevertheless, the most recent burial event might be missing from Hurliman and Little Nestucca cores. For this study, the uppermost buried peat at the Hurliman and Little Nestucca core sites will be considered the 1MT horizon. 


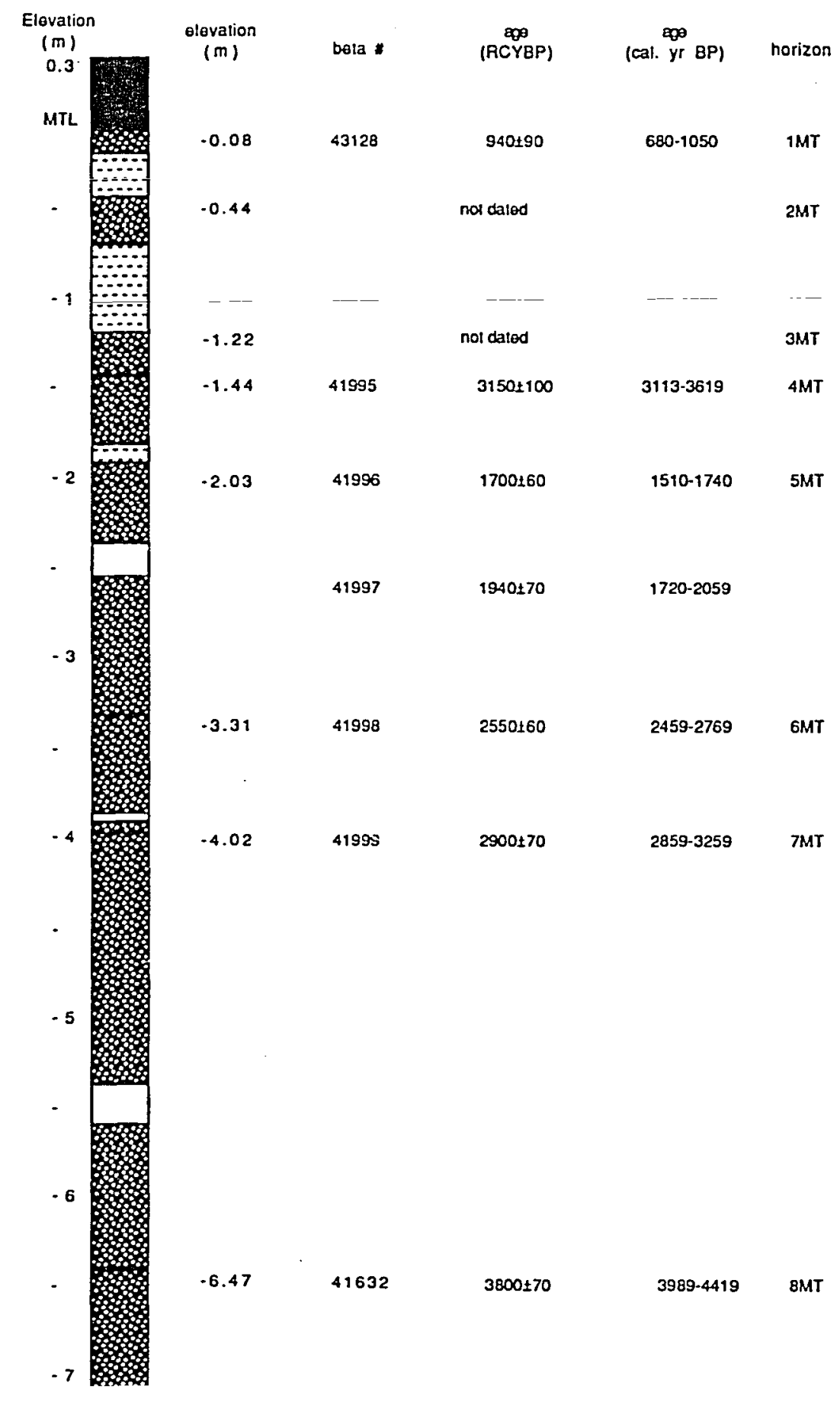




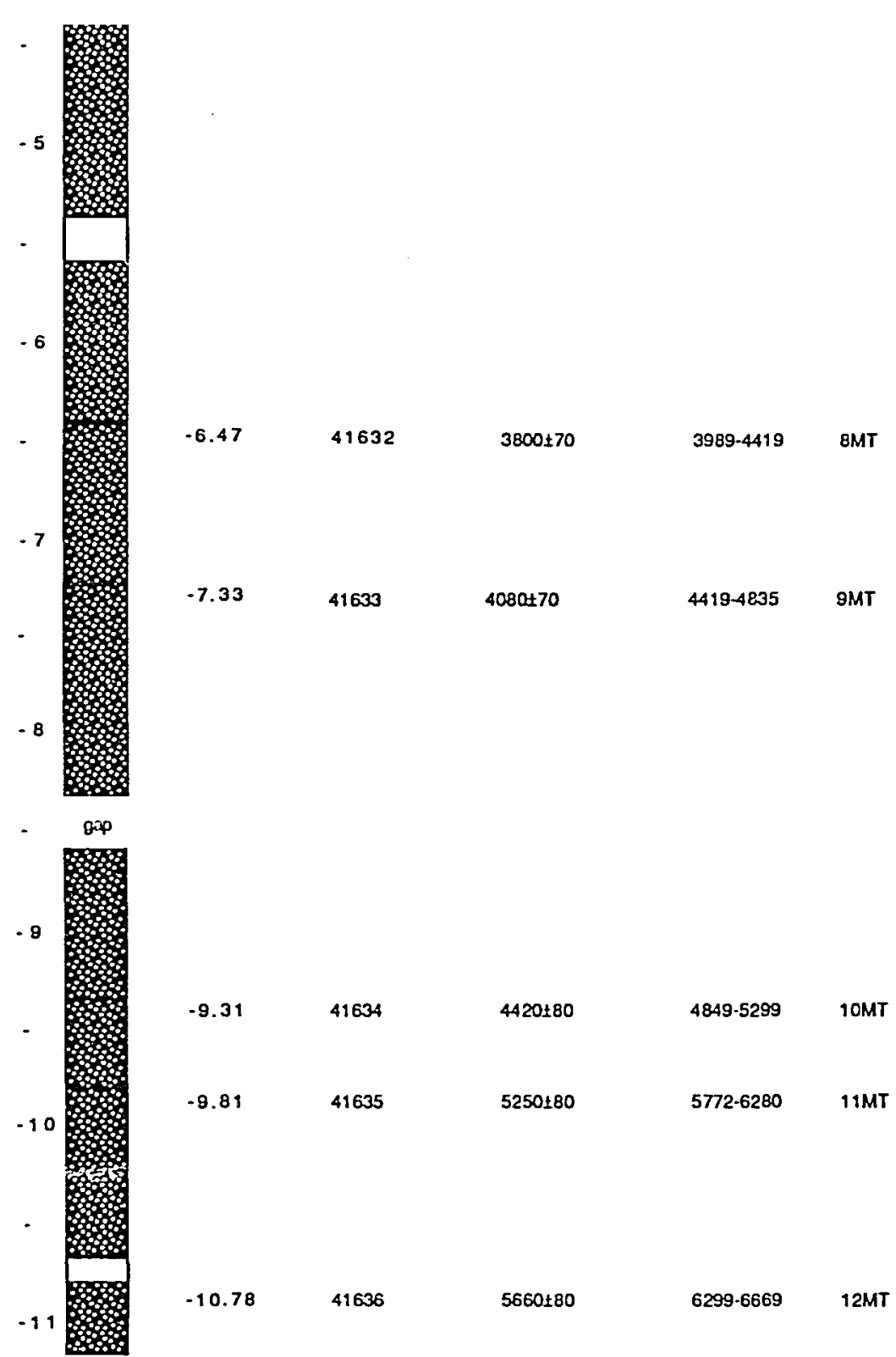

Figure 23. Radiocarbon ages of buried peats from Hurliman 2. 



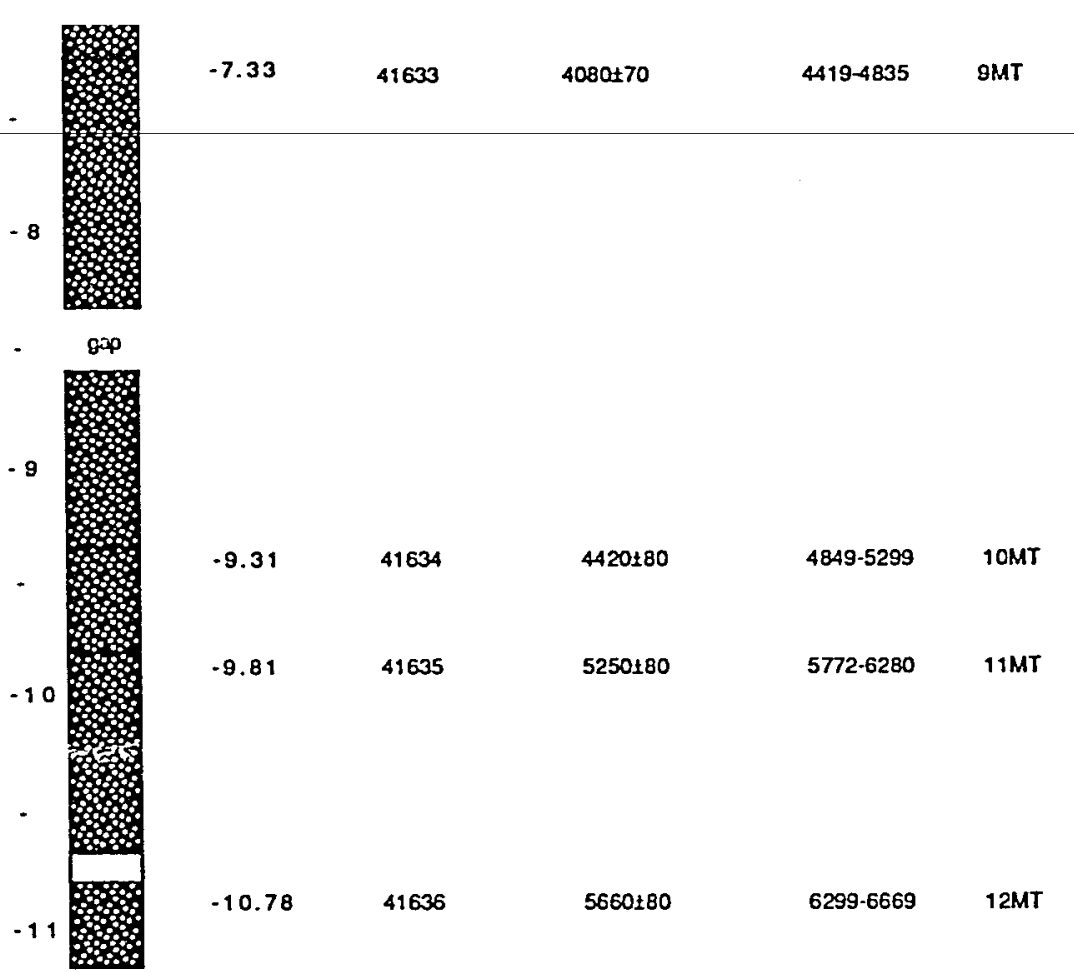

Figure 23. Radiocarbon ages of buried peats from Hurliman 2. 



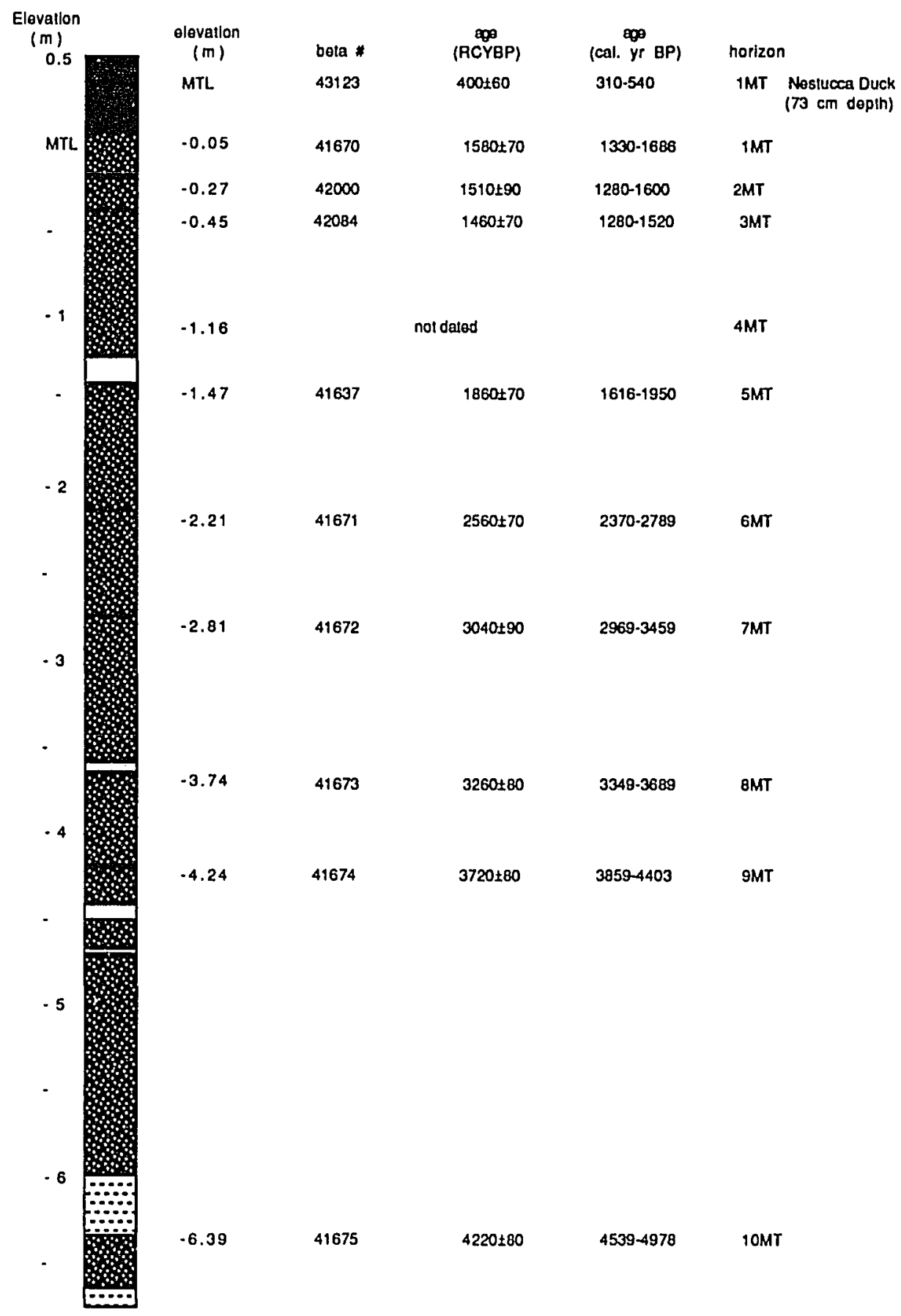

Figure 24. Radiocarbon ages of buried peats from Little Nestucca 5. 


\section{SILETZ BAY}

\section{Hydrography and Physiography}

Siletz Bay is approximately $153 \mathrm{~km}$ south of the Columbia River and is bounded on the west by a sand spit and on the east by the Coast Range (Figures 1 and 25). The major tributary into the bay is the Siletz River. The drainage is made up of mostly Tertiary volcanic rocks (basalt), intrusive rock, and estuarine and marine sedimentary rock, such as feldspathic/ micaceous sandstones and siltstones (Baldwin, 1981). The river is $116 \mathrm{~km}$ in length and the head of tide is at river kilometer 38.9. The river-dominated estuary drains an area of $966 \mathrm{sq} . \mathrm{km}$ ( $82 \%$ is Siletz River drainage) which yields approximately $2.2 \times 10^{9}$ cubic meters of freshwater annually ( $78 \%$ from the Siletz River). The rest comes from Drift Creek and to a lesser extent Schooner Creek. The mean tide range is 1.5 meters and a tidal prism on mean range (between MLLW and MHHW) is $9.9 \times 10^{6}$ cubic meters. The Siletz River and the creeks carry about 67,100 metric tonnes of sediment into the bay per year (Percy et al, 1974). The summer areal distribution of sediment and relative abundances of beach and river derived sand in the bay is documented by Peterson et al (1984). They found that sand is a major component of the bay except for the southern part of the bay between the spit and the Millport Slough marshes. There, mud is the major component of the estuarine sediments. Beach-derived sand is most abundant toward the mouth of the estuary and diminishes to less than $25 \%$ in the southern part of the bay. Wetlands (salt marsh) make up about $18.8 \%$ of the estuary with most of the wetland beinghigh salt marsh (68\%) (Oregon

Department of Land Conservation and Development, 1987). 


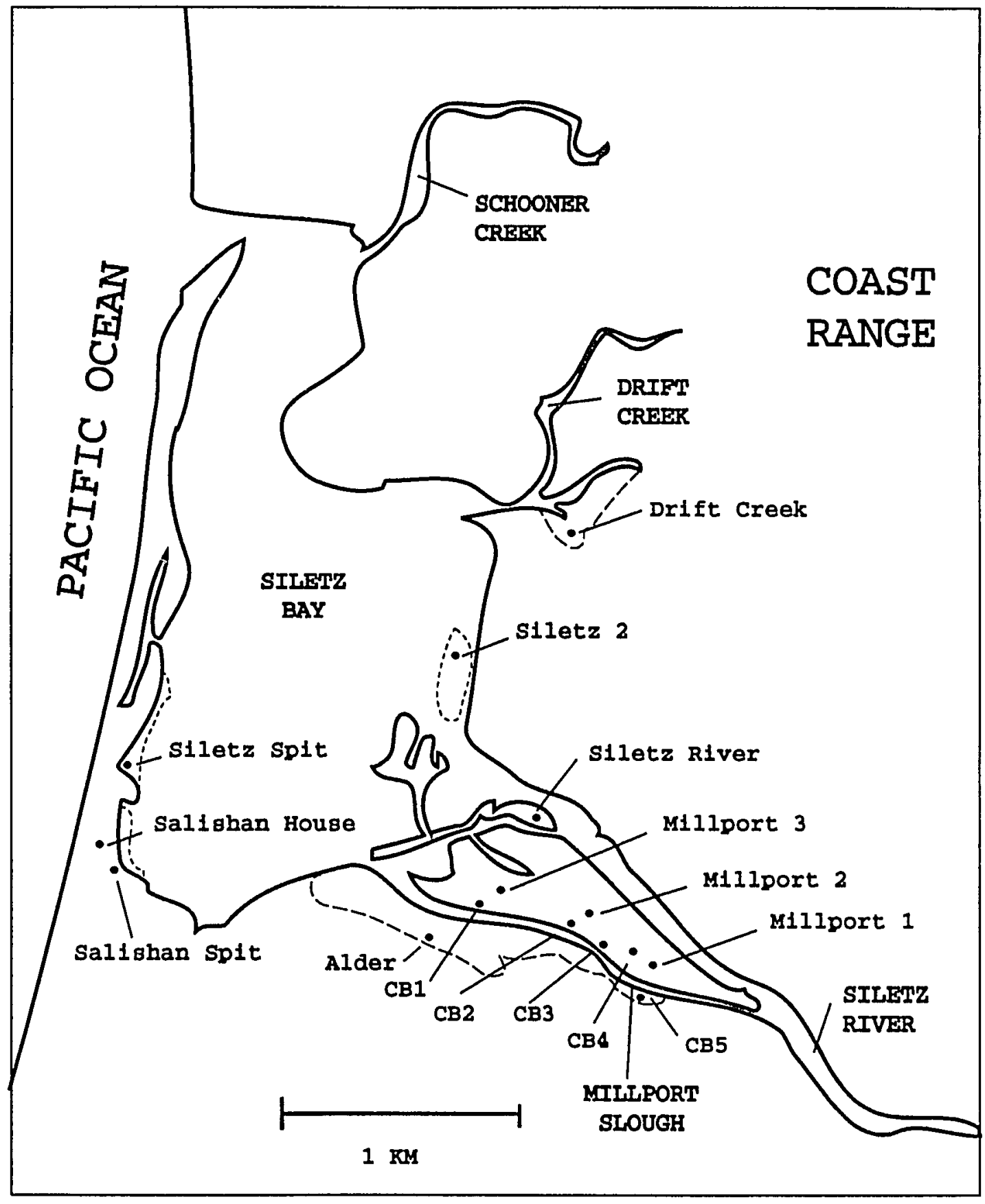

Eigure 25. General setting and core site and cutbank locations on marsh (short dashes) or pastureland (long dashes) for Siletz Bay. 


\section{Core Locations and Tidal Elevations.}

Three locations were cored on the bay side of the spit, six in the Millport Slough area and one near Drift Creek (Figure 25). Vibracores were taken at the Salishan House and Millport 1 sites. Cutbank exposures along Millport were not extensive due to minimal exposure at low tide and slumping. However, a few sites in small tidal creeks draining into Millport were examined. Although tide gauges had been established in Siletz Bay (Taft), the sites were not surveyed to tidal benchmarks, because of the great distances from the core sites to the benchmarks. Nevertheless, all core sites were surveyed into water levels and because tidal data were available in Siletz Bay, as well as a tidal study by Goodwin et al (1970), the water levels were compared to the published data and mean tidal levels were estimated for the core sites (Appendix D).

\section{Detailed Stratigraphy}

Stratigraphy for the cores and cutbanks of Siletz Bay are summarized in Figures 26-28. Seven burial events in $3.25 \mathrm{~m}$ are recorded in Siletz Bay and five events in $2 \mathrm{~m}$ are recorded at two locations within the bay, Salishan Spit and Millport 1, that are separated by $3 \mathrm{~km}$. The five events are correlatable based on depth below the surface and/or presence of sediment capping layers. All contacts, with minor exceptions, between the buried peat and overlying lower organic sediments (S) or sediment capping layers (SCL) were abrupt. In contrast, $80 \%$ of the contacts of the buried peat with the underlying lower organic sediment (S) were gradual.

Four out of the top five buried peats (except 3MT) at Salishan House were overlain by distinct S's or SCL's (barren to rooted sand or muddy sand). In turn, SCL's (barren to rooted sandy mud to muddy sand) were identified above 4, 5, and 7MT at Millport 1 and 2. Triglochin rhizomes were found above 


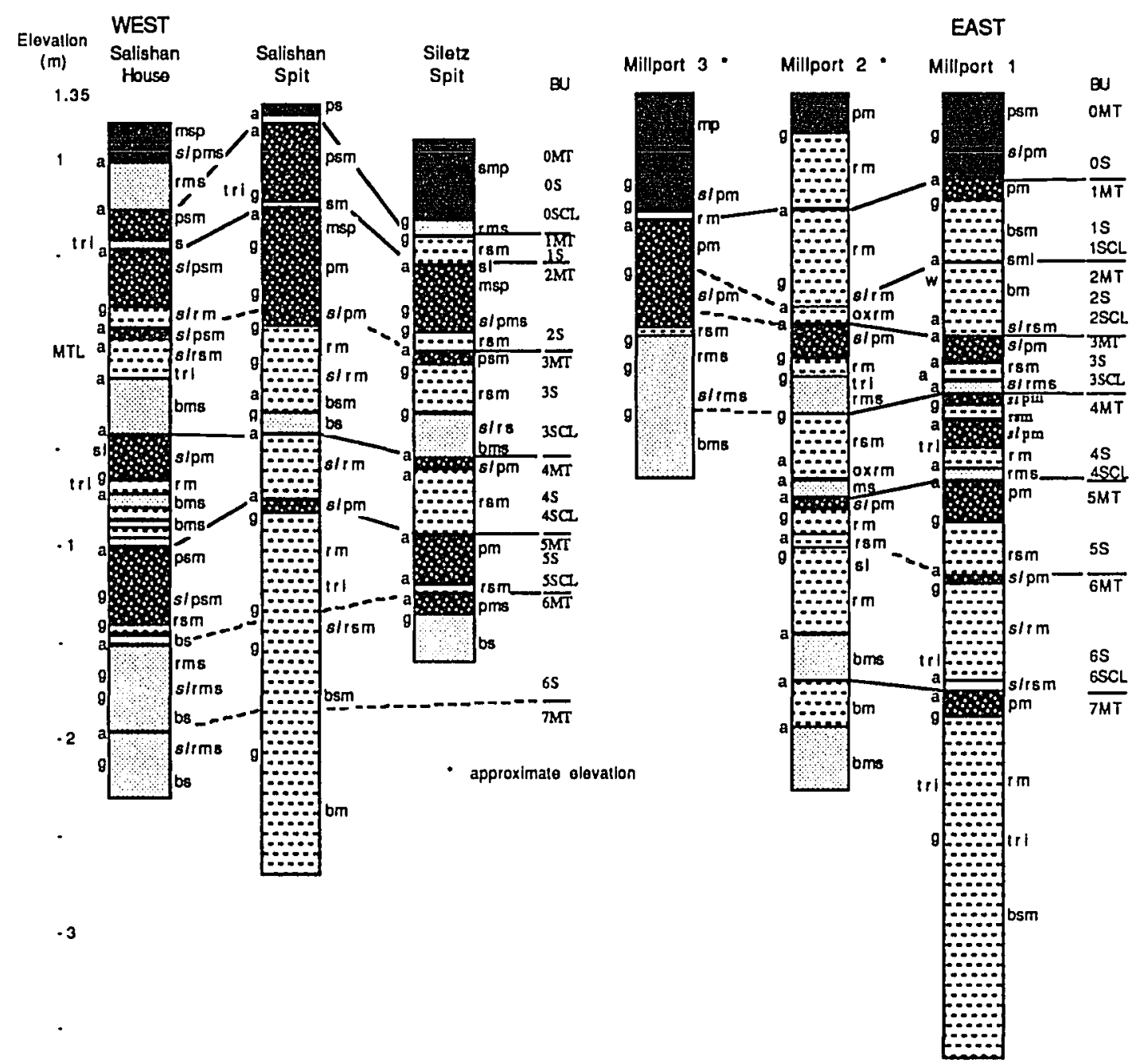

Figure 26. Stratigraphy of the cores from sites on the Siletz Spit and Millport Slough.

2MT (within sand and sandy mud of 1S) at Salishan House and Salishan Spit, above 4 and 5MT (within rooted sandy mud and rooted mud above 3 and 4SCL) at Salishan House, above 5 and 7MT (within rooted mud) at Millport 1, above 4MT (within rooted muddy sand) at Millport 2, above 2MT (within rooted mud) at Alder, and above 1MT (within rooted mud) at Siletz 2). 1MT is visible in several cutbank locations (Figure 28) in the Millport Slough area, but it was 


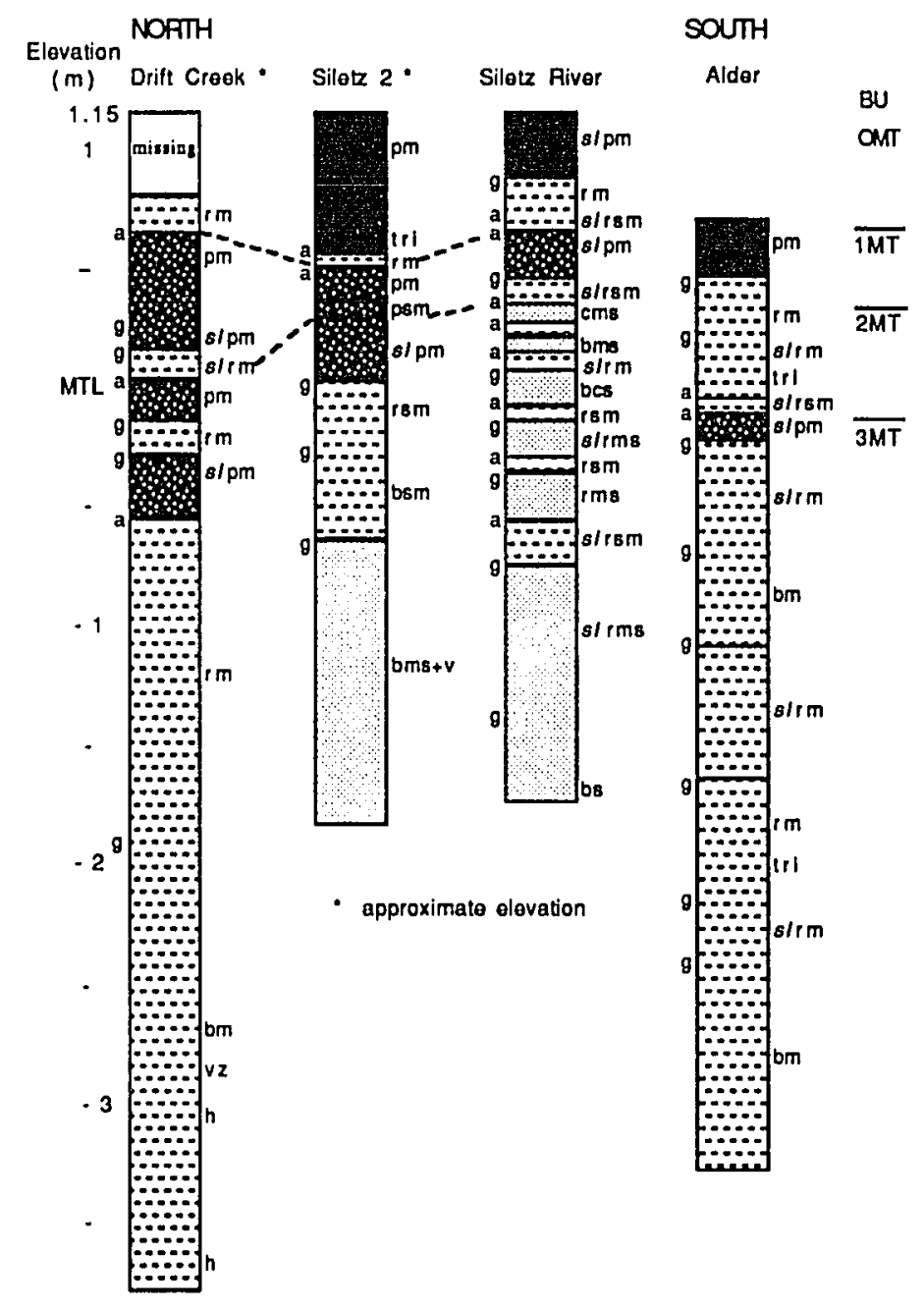

Eigure 27. Stratigraphy of the cores from additional sites in Siletz Bay.

difficult to trace over the length of the slough, because of slumping and poor exposure. The buried peat between 4 and 5MT at Miliport 1 was not included as a distinct burial unit, because it was not identified in other cores.

\section{Laboratory analyses}

Detailed analyses were completed on Salishan House and Millport 1 cores. Selected samples from Siletz River, Millport 2, and Alder were also 


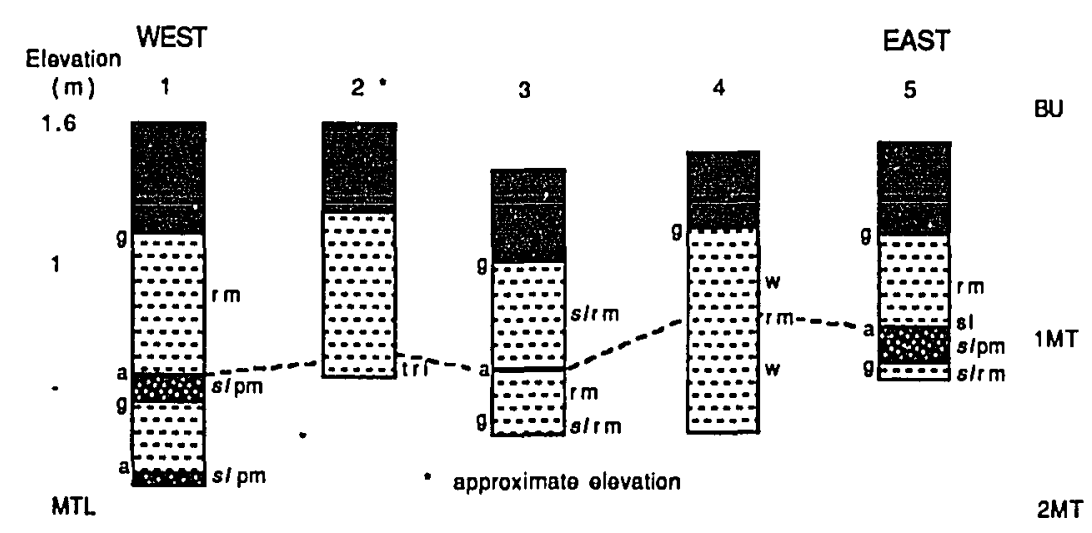

Figure 28. Stratigraphy of cutbanks along Millport Slough.

analyzed. See Appendix $F$ for summary of results. All burial events at both Salishan House and Millport 1, except the 2MT to 1S transition, showed a decrease in organics over that interval and all transitions from the S/SCL horizon to the overlying MT horizon showed an increase, except from $2 S$ to $2 M T$ at both sites (Figures 29-30). Percent sand increased from the MT to the immediately overlying SCL or S horizons, except for the 3MT to $2 S$ transition at Salishan House and the 1MT to 0S transition at Millport 1 (Figures 29-30). From the SCL to the overlying MT horizon the percent sand decreased in all cases. In contrast, at Salishan House where MT horizons were overlaid by a distinct SCL and S horizon, the percent sand in the overlying S horizon, in two of the three cases, was less than the percent sand in the MT horizon (5MT to $4 \mathrm{~S}, 6 \mathrm{MT}$ to $5 \mathrm{~S}$ ) and in four out of seven instances, the percent sand from the $\mathrm{S}$ horizon to the overlying MT horizons increased. By comparison, there was only one case out of four (7MT to $6 S$ ) at Millport 1 where the percent sand of the $S$ horizon was less than the underlying MT horizon, given a distinct $S C L$ and $S$ horizon, and in only one out of five cases did the percent sand from the $S$ horizon to the overlying MT horizon increase. All diatom assemblages were 
$\%$ LOI Sal

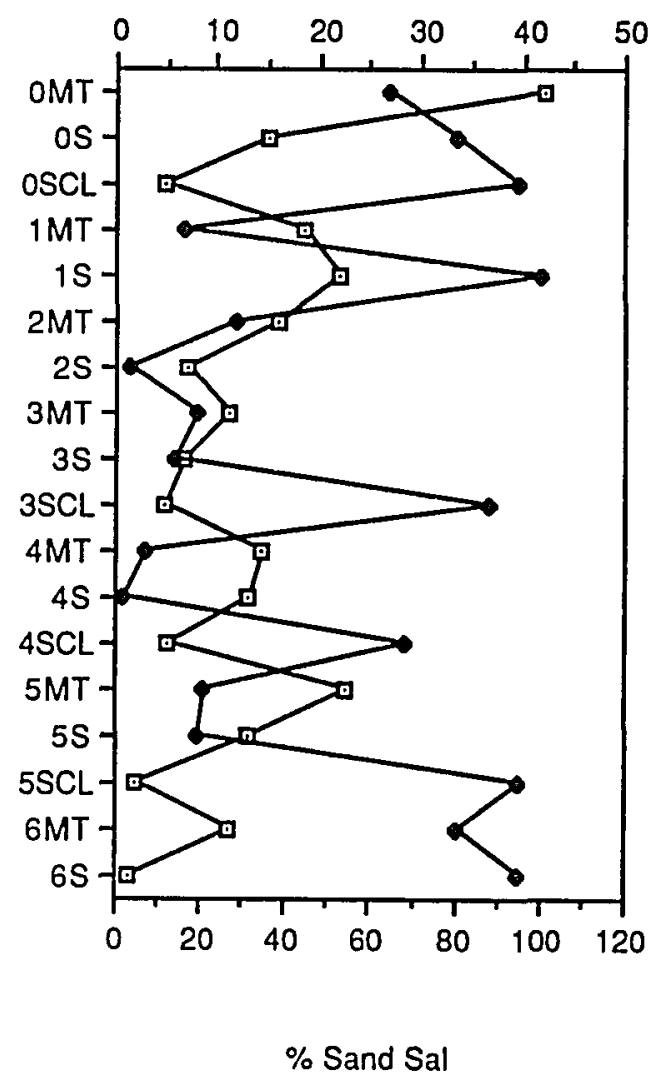

Eigure 29. Plot of burial horizons vs. percent loss on ignition and percent sand for Salishan House. Sand = Diamonds; LOI = Squares.

brackish-marine, thus there were no significant diatom trends from the MT to overlying S/SCL horizon (Appendix F).

Heavy minerals of samples from Salishan House and Millport 1 and 2 were examined for beach or river sand source (appendix F). In the Salishan core, both the MT and SCL horizons were predominately beach sand (96$100 \%$ ), except for 4SCL (21\%). However, the $2 \mathrm{MT} / 1 \mathrm{SCL}$ and $4 \mathrm{MT} / 3 \mathrm{SCL}$ transitions did show a coarsening of the beach component upward. These two 
$\%$ LOI Mill 1

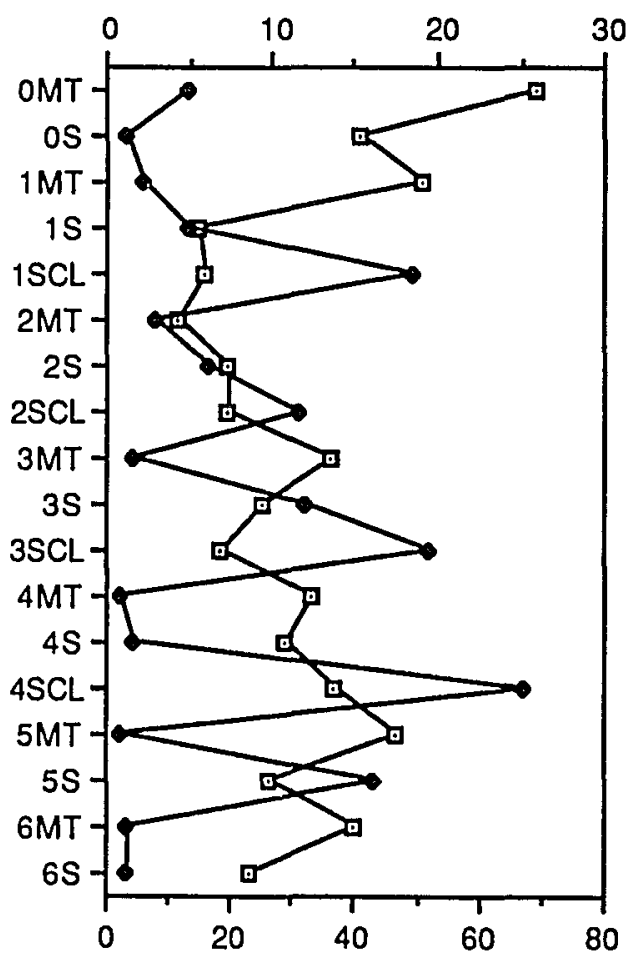

$\%$ Sand Mill 1

Figure 30. Plot of burial horizons vs. percent loss on ignition and percent sand for Millport 1. Sand = Diamonds; $L O I=$ Squares.

cases would therefore be considered positive and would indicate a eolian spittidal bay source for sediments in the MT horizon and perhaps a beach source for the SCL's. However, the 5MT/4SCL transition was reversed (thus negative), in that a significant river component was found in the overlying SCL instead of the MT horizon. In contrast, Millport 1 and 2 and Millport cutbank 5 sands were exclusively river. In almost all transitions, however, where a distinct SCL was present, the river sands coarsened in the SCL layer (positive) indicating either a higher carrying capacity of the river or a lower elevation for 
coarser sediments to be deposited. It should be noted that the sand component in the southern part of Siletz Bay, both east and west of where the cores were taken, is predominately river-derived (Peterson et al, 1984). Here, a tsunami surge might deposit an anomalously high percentage of river sand over a coseismically submerged back spit marsh that normally receives most of its sand from the spit through eolian transport.

\section{Radiocarbon Ages}

Radiocarbon age determinations were made on peats from both Salishan House and Millport 1 (Figures 31 and 32). All events were dated. Salishan House had the most complete record. The third event at Salishan (3MT) was not dated because of the lack of sufficient organic material.

\section{YAQUINA BAY}

\section{Hydrography and Physiography}

Yaquina Bay is about $185 \mathrm{~km}$ south of the Columbia river and is bordered by the Coast Range to the east and moderately high sea cliffs (north of the mouth) and sand dunes (south of the mouth) to the west (Figures 1 and 33). The major tributary into the bay is the Yaquina River. The drainage is made up mostly of Tertiary estuarine and marine sedimentary rocks, such as mudstones and tuffaceous/feldspathic/ micaceous sandstones and siltstones (Elaldwin, 1981). The river is $94.6 \mathrm{~km}$ long with the head of tide at river kilometer 41.8 . The estuary drains an area of $655 \mathrm{sq} . \mathrm{km}$, with an average annual freshwater yield of $9.6 \times 10^{8}$ cubic meters. The mean tide range is 1.8 meters and the tidal prism on mean range is $2.4 \times 10^{7}$ cubic meters. The sediments deposited in the bay average 27,200 metric tonnes per year (Percy et al, 1974). Areal 


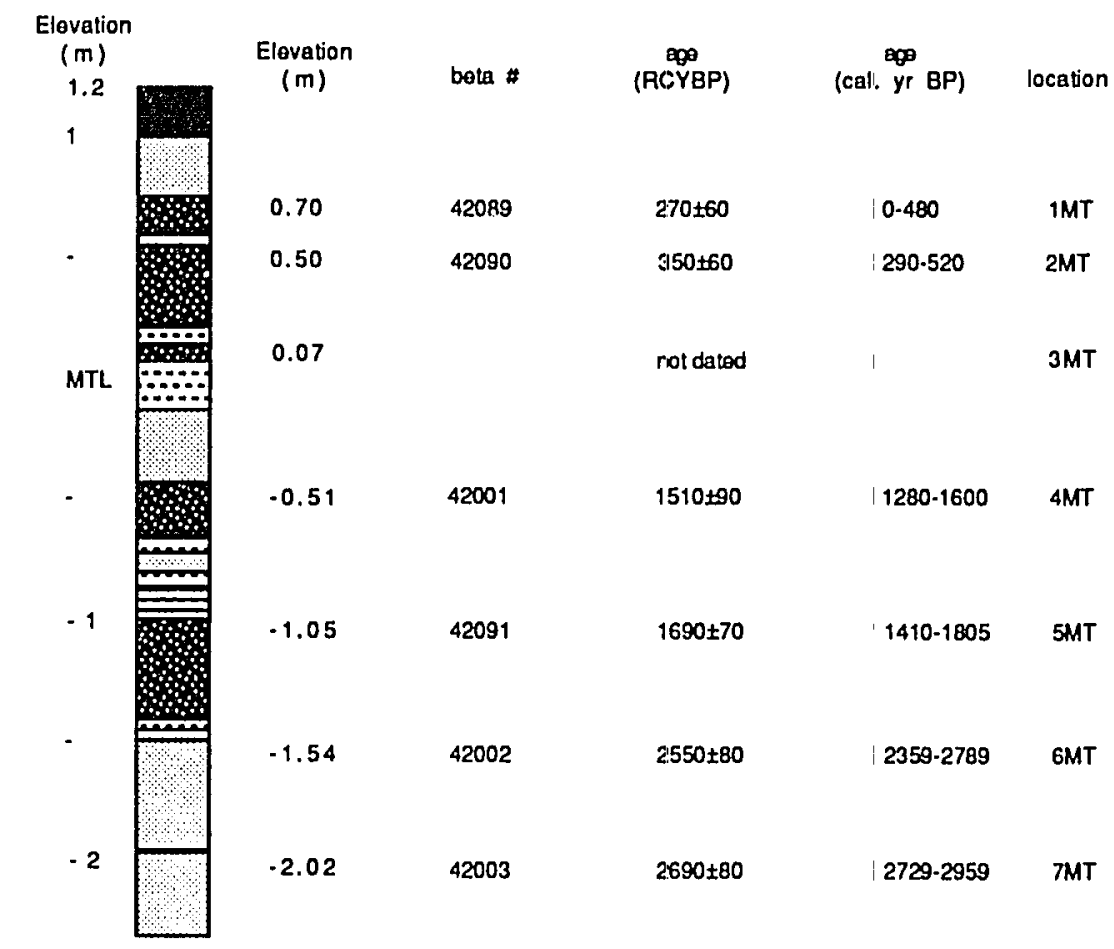

Eigure 31. Radiocarbon ages of the buried peats from Salishan House.

distribution of sediment and relative abundances of beach and river-derived sand in the bay is documented by Kulm and Eiyrne (1967). Wetlands (salt and freshwater marsh) makes up $14.2 \%$ of the estuary with most of it being high salt marsh (76\%)(Oregon Department of Land Conservation and Development, 1987).

\section{Core Lecations and Tidal Elevations}

Three cores were taken in pasture south of the Hatfield Marine Science Center, five cores were taken in marsh land along Poole Slough, one in a marsh near Blind Slough, and ten cores in pasture land upstream of the city of Toledo near the confluence of Slack Creek and Yaquina River. Cutbanks were examined in four locations along Poole Slough and along a $500 \mathrm{~m}$ stretch of the 


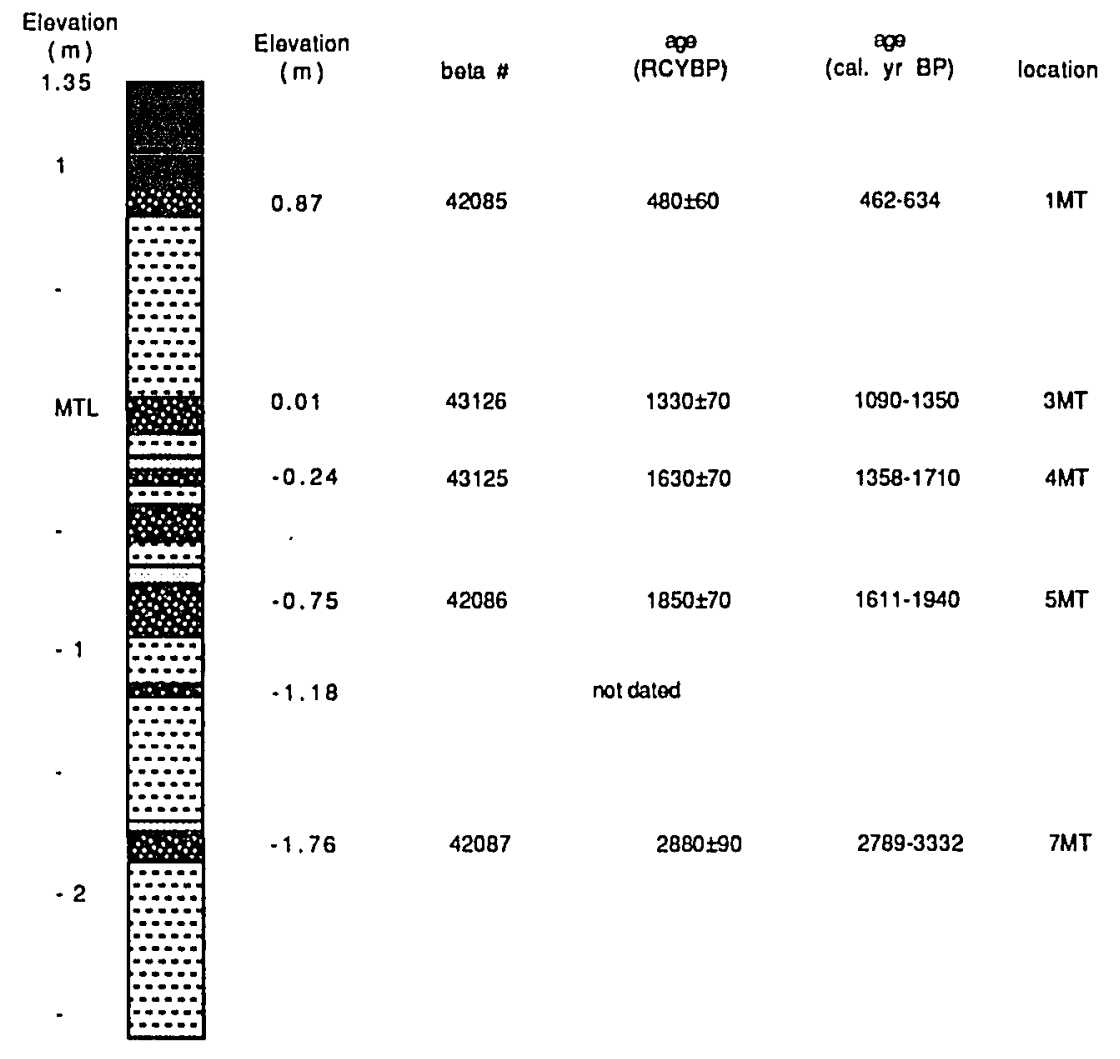

Figure 32. Radiocarbon ages of the buried peats from Millport 1.

Yaquina River upstream of the Slack Creek mouth (Figure 33). An enginepowered vibracore was taken at the Slack 1 core site and a human-powered vibracore at the Hatfield site.

All core sites were surveyed to water level. The sites were not tied into existing tidal benchmarks because of the great distances to them. The Slack and Conser core sites and the cutbanks on the Yaquina River were, however, tied into a benchmark found on the bridge over Slack Creek. The tidal records from the gauges established in the Yaquina estuary, were used to estimate core site elevations. Modern marsh and tide flat locations near the Hatfield sites were also surveyed into water level (Appendix D). 


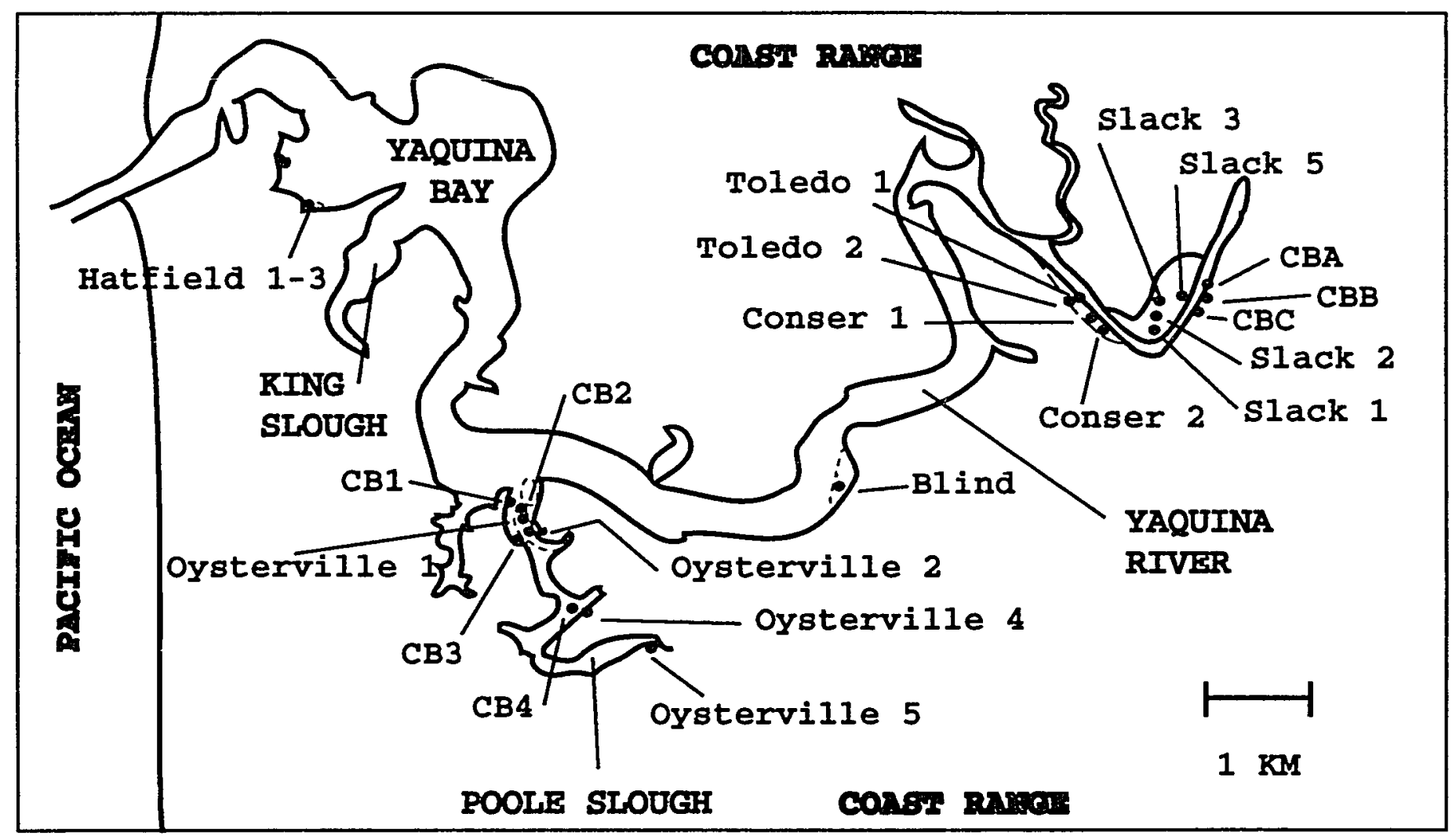

Figure 33. General setting and core site and cutbank locations on marsh or pastureland in Yaquina Bay. 
Detailed Stratigraphy

The stratigraphy for the core and cutbank sites are summarized in Figures 34-38. The cutbank and Slack stratigraphy were combined, because 1) the surface of the cutbank was $2 \mathrm{~m}$ above the Slack site surface, 2) burial events identified in the cutbank were also elevationally above the Slack surface, and 3) the radiocarbon age of the uppermost buried peat at Slack was 1350 yrs B.P. and the age of the second buried layer in the cutbank was much younger (550 yrs B.P.). In other words, the Slack site perhaps did not record this event. The uppermost buried layer in the cutbank was given a $0^{\prime}$ designation, because of its shallow depth below the surface, the young age of the layer below it, possible correlation with the top most layer (also $0^{\prime}$ ) at Hattield (160 yrs B.P.), and the occurrence of a similar shallow young horizon (160 yrs B.P) in Alsea Bay. In addition, a shallow buried tree stump located in South Slough, an estuary in the south central part of Oregon and $120 \mathrm{~km}$ south of Alsea, yielded a radiocarbon age of $140 \mathrm{yrs}$ B.P. The $0^{\prime}$ designation was also used in Alsea Bay and South Slough. This young horizon has not been assigned to marsh stratigraphic columns north of Yaquina, because none of the top most buried peats at the other bays have recorded an age younger than 270years B.P. The uppermost buried peat at Slack was designated 3MT, because of its stratigraphic position and age. The Hatfield buried peats were designated as $0^{\prime} \mathrm{MT}$ and $3 \mathrm{MT}$, owing to their radiocarbon ages, as well as age and depth comparisons to Alsea Bay buried peats. These comparisons will be addressed in the Discussion section.

Burial events are found throughout the Yaquina estuary, although sites with burial records were few. Nine burial events (3MT-11MT) above $6.0 \mathrm{~m}$ depth were identified at the Slack 1 core site and three $\left(0^{\prime}-2\right)$ in the cutbank 


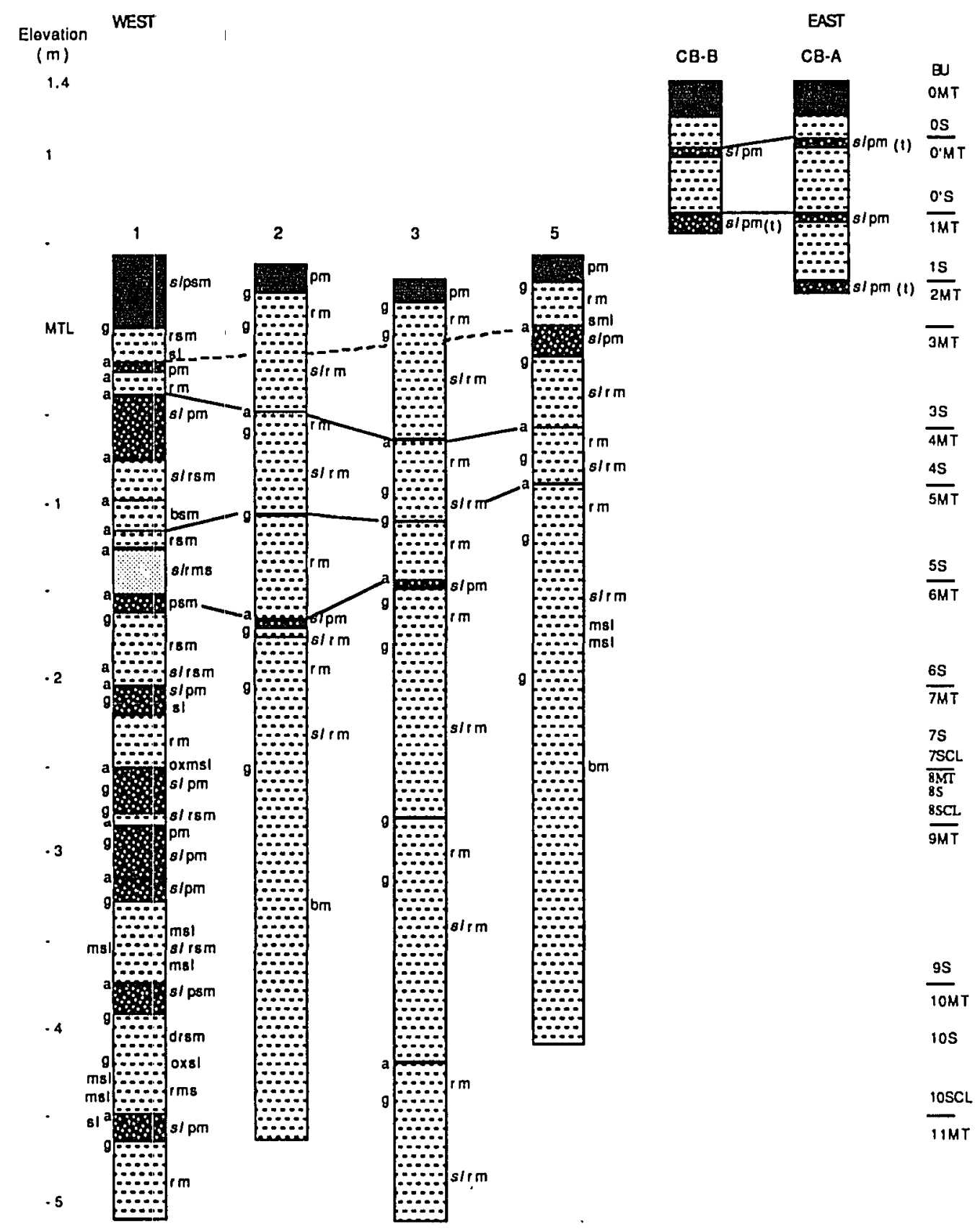

Eiqure 34. Stratigraphy of the Slack cores from sites in the upper tidal reaches of the Yaquina River. 


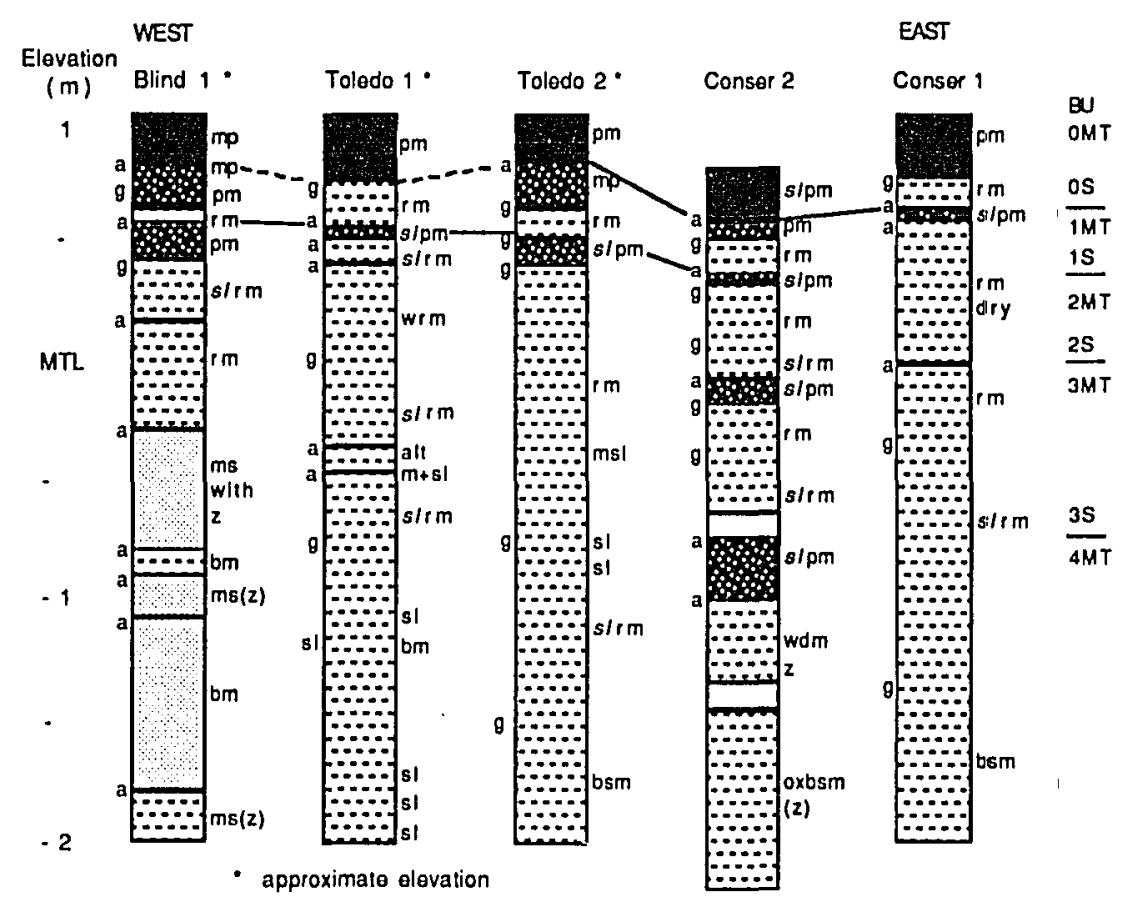

Figure 35. Stratigraphy of the Conser, Toledo and Blind cores from sites in the upper reaches of the Yaquina River.

nearby. Correlation between events identified in the lower (Hatfield ${ }_{h}{ }_{h}$ central (Oysterville), and upper (Slack and Conser) estuary is difficult because of the lack of diagnostic features and great distances between sites. Almost all contacts between the buried peat and the overlying S or SCL horizon were abrupt and $80 \%$ of the contacts between the buried peat and underlying $S$ horizon were gradual.

There were several distinct SCL's or S horizons above buried peats. They were recognized at the Hatfield sites (above $0^{\prime}$ and 3 ) in the western part of the estuary, at the Oysterville 4 site (above $0^{\prime}$ and $1 M T$ ) in the central section, and at the Slack 1 site (above 3, 6, 8, 9, 10, and 11MT) in the eastern section. In addition, a very sandy layer was identified above O'MT in cutbank C (Figure 33), which had a similar stratigraphy as cutbanks $A$ and $B$ but the organic-rich 


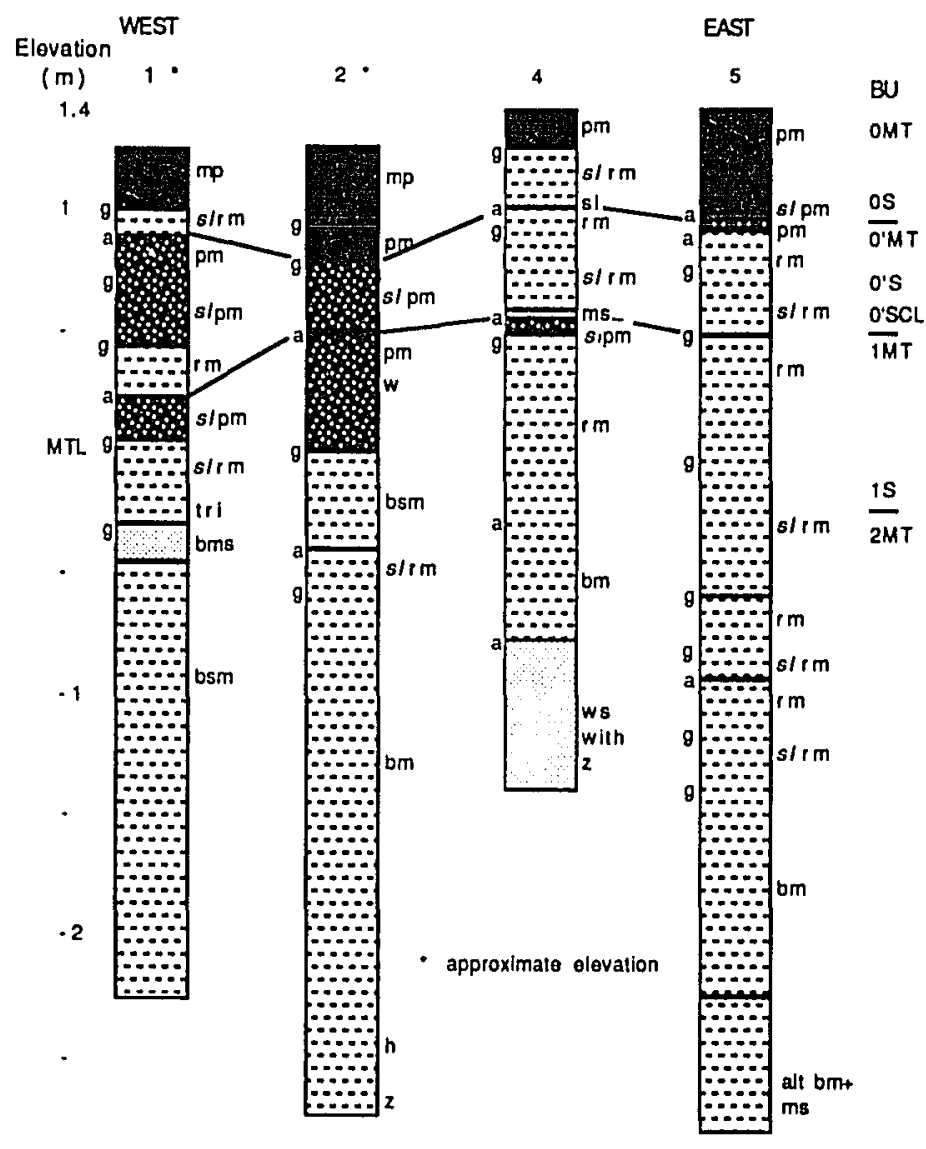

Fiqure 36. Stratigraphy of the Oysterville cores from sites along Poole Slough near the central reaches of the Yaquina.

horizons were much thinner and lacked tree roots. No Triglochin rhizomes were found above buried peats (MT horizon). Although in the Hatfield cores, they were found slightly below the MT horizon, indicating that the plant was probably established above the buried peat.

\section{Laberatery Analyses}

Samples from cores of the lower (Hatfield 1,2), central (Oysterville 1 and 2), and upper (Slack 1) Yaquina estuary were analyzed in detail (Appendix F). The organic content decreased from the MT horizon to the immediately overlying SCL or $S$ horizon and increased from the $S$ to the overlying MT 


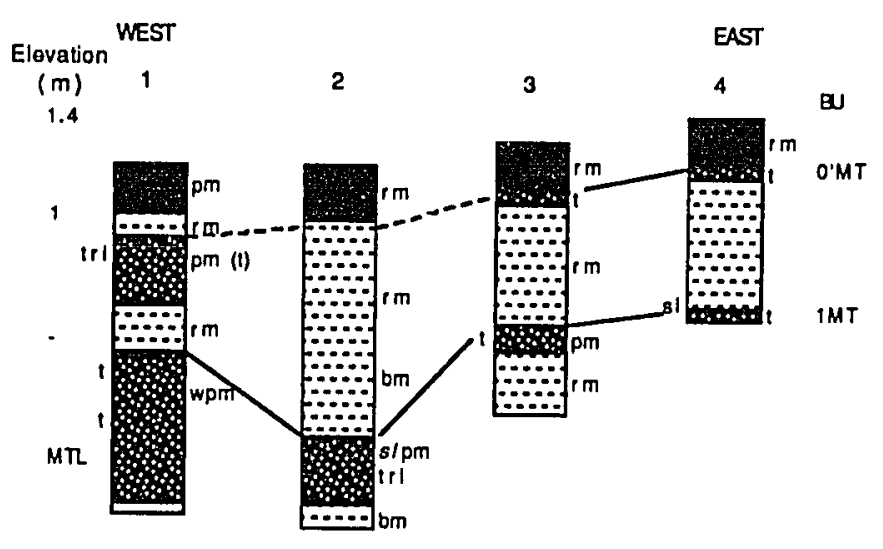

Figure 37. Stratigraphy of the cutbanks along Poole Slough.

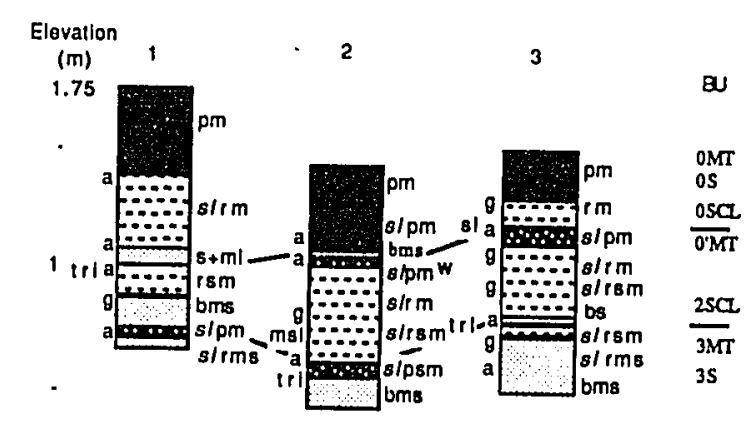

Figure 38. Stratigraphy of the Hatfield cores from a site in the lower reach of the Yaquina estuary.

horizon for all cases (Figures 39-41). The percent loss on ignition for the O'MT, O'S and 1MT horizons are estimates only. There was only one example where the organic content in the S horizon, in association with a SCL, was greater than the underlying MT horizon (0'MT to OS in Hatfield 2). $80 \%$ of the time at Slack 1, the sand content increased from the MT to the immediately overlying SCL. or S horizon (Figures 39-41). In $60 \%$ of the cases the sand content decreased from the $S$ to the overlying MT horizon and the remaining $40 \%$ of cases either did not change or increased slightly. At Oysterville 2, only one interval had any significant change and that was an increase in sand from 2MT to $1 \mathrm{~S}$. In contrast to Oysterville, the sand content from the MT to overlying SCL 
$\%$ LOI Slack 1

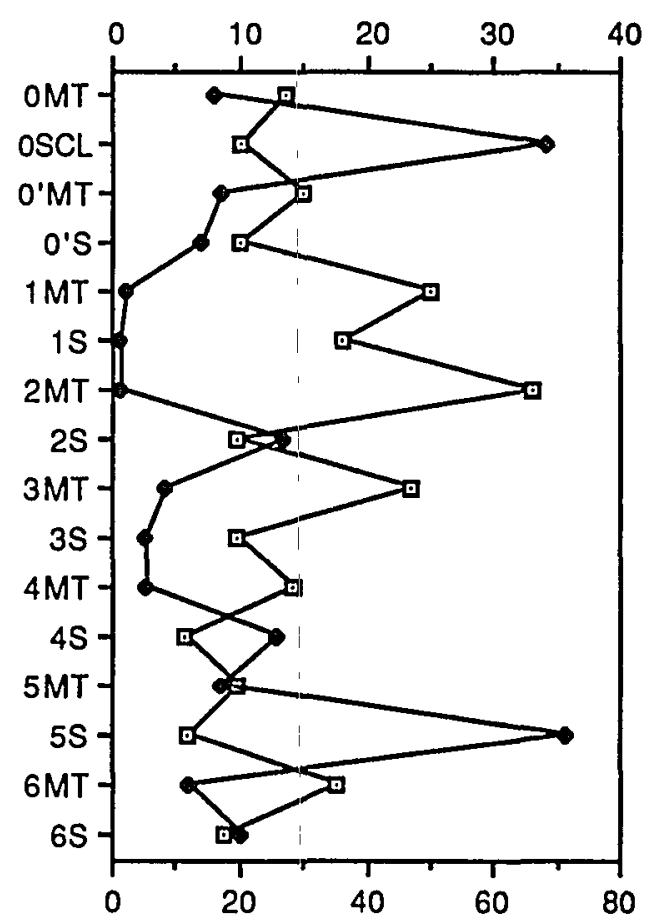

\%Sand Slack1

Eigure 39. Plot of burial horizons vs. percent loss on ignition and percent sand for Slack 1. Sand = Diamonds; $L O I=$ Squares.

or $S$ horizon increased. By comparison, sand from the SCL and $S$ to overlying MT horizon decreased in the Hatfield cores. No significant trends in diatom assemblages were noted in the MT to overlying SCLS transition at Slack 1 or Oysterville 1 and 2. However, a change from brackish to brackish-marine assemblages was noted at all transitions (O'MT to OSCL and $3 M T$ to $2 S C L$ ) recorded at Hatfield.

The beach sand component at Hatfield was $100 \%$ beach for all horizons, although there was a coarsening of beach sand from 3MT to 2SCL. The Slack 
$\%$ LOI Oyst

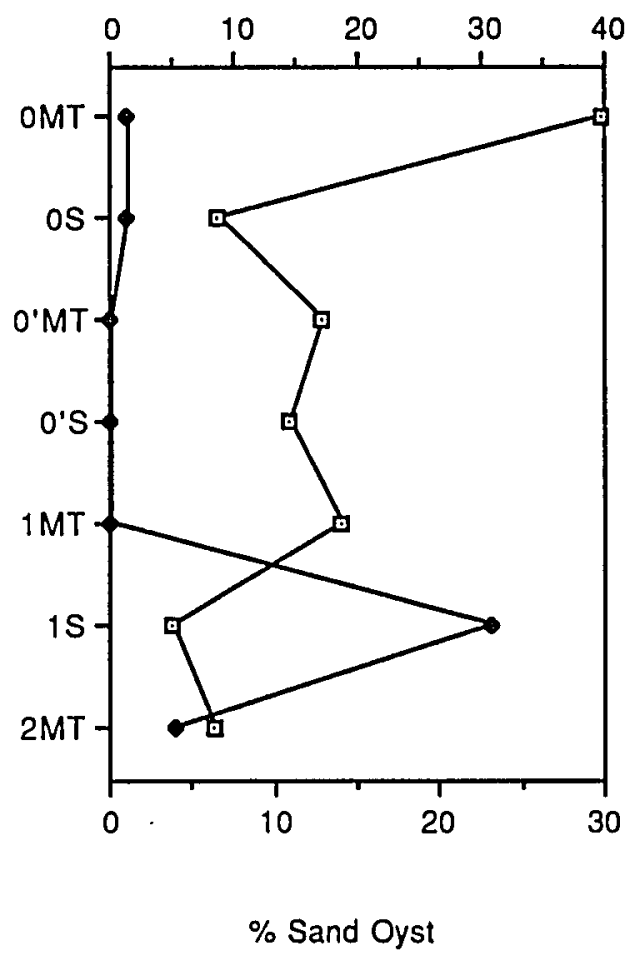

Figure 40. Plot of burial horizons vs. percent loss on ignition and percent sand for Oysterville 2. Sand = Diamonds; LOI = Squares .

site and Oysterville SCL's showed no evidence of a beach component, although there was a coarsening of river sand above 6MT and 11MT at Slack (Appendix F). The scarcity of marsh localities in Yaquina Bay and along the Yaquina River east of the Hatfield site presents problems documenting evidence for a tsunami surge in the Yaquina estuary.

\section{Radiocarbon Ages}

Radiocarbon ages were determined for buried peats from Slack 1 and Hatfield. All events recorded at Hatfield and 8 of the 9 buried peats at Slack (5MT) were dated (Figures 42-43). In addition, wood from the second buried 


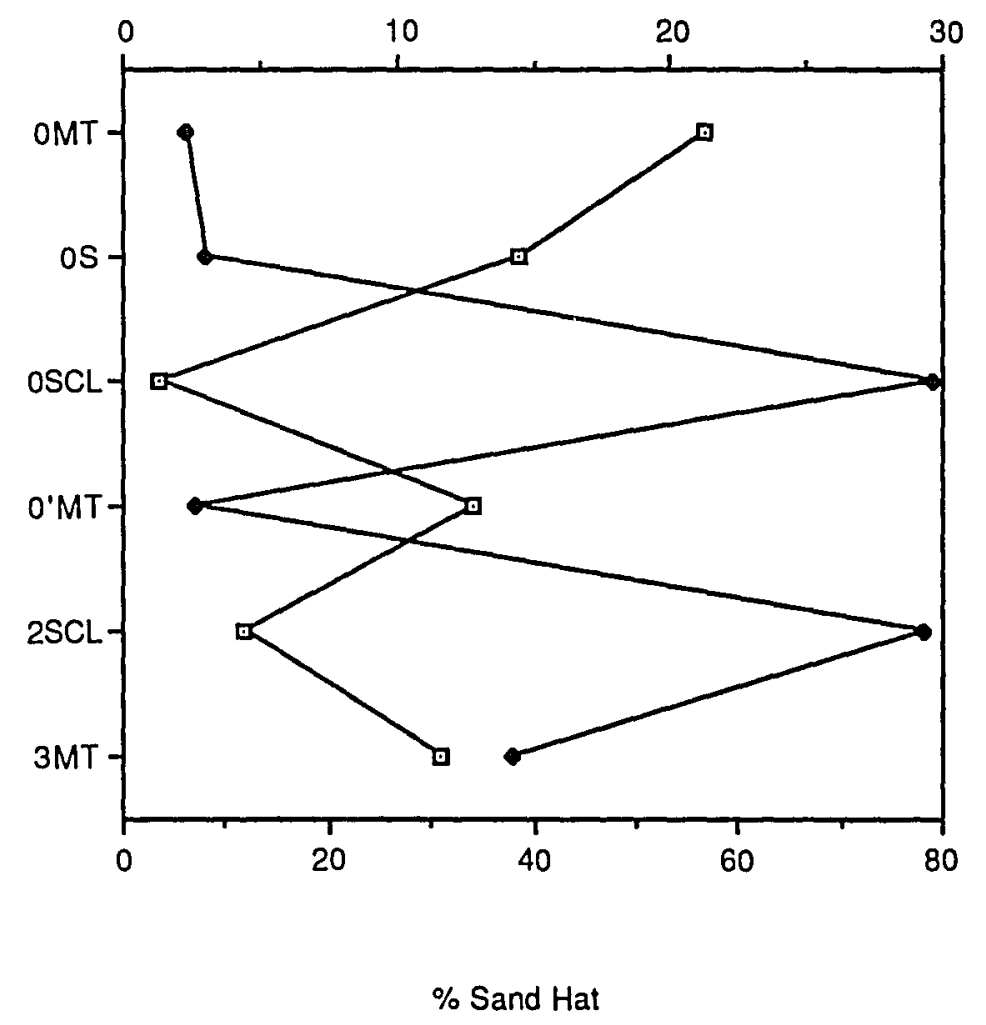

Eiqure 41. Plot of burial horizoris vs. percent loss on ignition and percent sand for Hatfield. Sand = Diamonds; LOI = Squares.

layer below the surface in cutbank B was dated. As at Nestucca, the age of the uppermost peat at Slack was older than anticipated (1350 years B.P.) and either two to three events are not recorded or the radiocarbon ages are incorrect. It's possible that the site, a mudflat environment, never recorded the events. This is supported by the presence of buried roots in the cutbank, whose surface elevation is close to 1.0 meters higher than the surface of the pasture, and the young age of the wood ( $550 \pm 70$ years B.P.). Based on the youngest 
age at Slack 1 and its elevational relationship with the cutbanks and Conser 1 and 2, it's assumed that the top most buried peat is the 3MT horizon.

\section{ALSEA BAY}

Hydrography and Physiography

Alsea Bay is approximately $208 \mathrm{~km}$ from the mouth of the Columbia River. The estuary is river-dominated and contains an extensive marsh systemin the upper reaches of the bay (Figures 1 and 44) (Peterson and Darienzo, 1991; Peterson et al, 1982 and 1984). Alsea River is $78 \mathrm{~km}$ long with a head of tide at river kilometer 25.7. The river drains an area of $1228 \mathrm{sq} . \mathrm{km}$ with an average annual freshwater yield of $1.85 \times 10^{9}$ cubic meters. The mean tide range is 1.77 meters and the tidal prism is $1.4 \times 10^{7} \mathrm{~m}^{3}$. The river deposits 225,843 metric tonnes of sediment per year into the bay (Percy et al, 1974). Wetlands (high salt marsh) make up approximately $18.3 \%$ of the estuary (Oregon Department of Land Conservation and Development, 1987).

\section{Core Locations and Tidal Elevations}

Nineteen sites were cored in the upper reaches of the bay over a distance of $3-4 \mathrm{~km}$ (Figure 44). Five of those sites were also cored with a vibracore. All of the core sites were located on high marsh. Cutbank exposures were examined over a distance of three kilometers. The mean tidal elevations for the core sites were established by surveying the sites into tidal bench marks (Peterson and Darienzo, 1991).

\section{Detailed Stratigraphy}

The stratigraphy is summarized in Figures $43-45$ and discussed in detail, along with the nature of contacts and the presence of SCL's, in Peterson and 


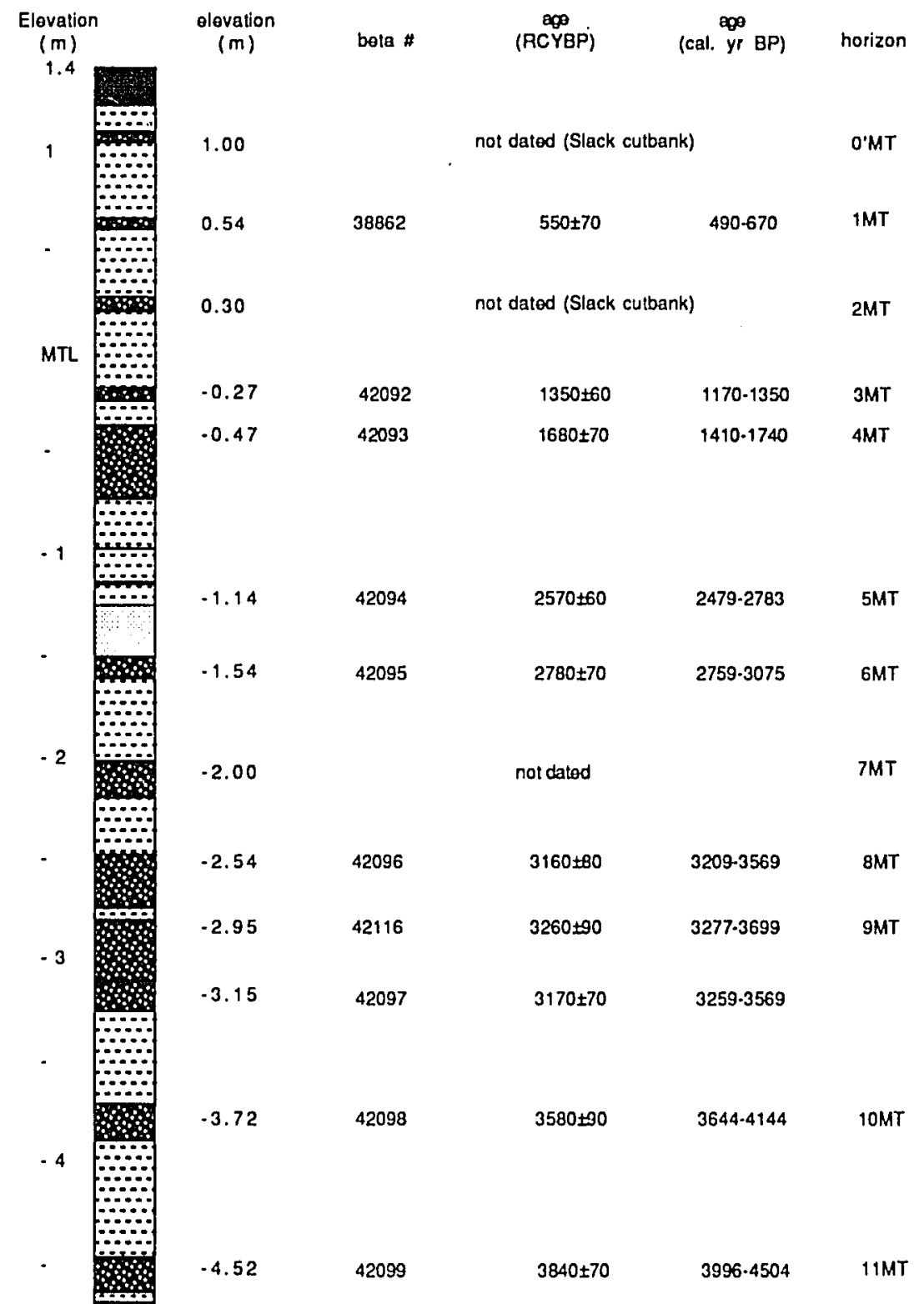

Figure 42. Radiocarbon ages of the buried peats from Slack 1 and CBB cutbank.

Darienzo (1991). Eleven burial events were identified in $7 \mathrm{~m}$ depth or $-5.5 \mathrm{~m}$ MTL. The best peat development was recorded at AB8 in the central marsh. The most recent event was given the 0 ' designation, as discussed in the 


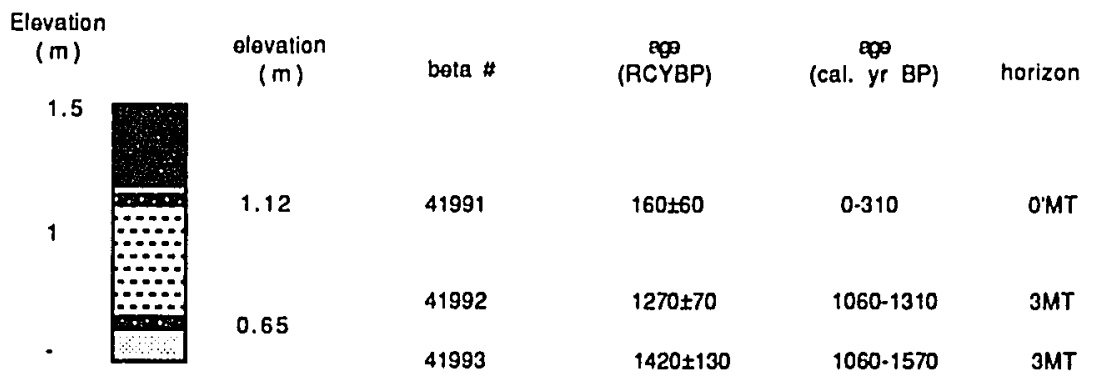

Eigure 43. Radiocarbon ages of the buried peats from Hatfield.

Yaquina Bay section. The other ten events were given burial unit numbers. No Triglochin rhizomes were found immediately above buried peats, except above 3MT at site AB5. Rhizomes were identified less than $20 \mathrm{~cm}$ below the buried peat surface of 2MT and 3MT of AB12 and 4MT of AB 10. The 1MT and 2MT burial horizons were laterally correlated in cutbanks over a distance of $3 \mathrm{~km}$. Occasionally, the 0'MT was identified in cutbank

\section{Laboratory Analyses}

Samples from core sites $A B 8, A B 12, A B 15, A B 19$, and $A B 21$ were analyzed for percent organic content, percent sand and heavy minerals. Analytical results are summarized in Peterson and Darienzo (1991). Most of the transitions from the MT to the overlying SCL or S horizon were abrupt. Usually the sand content increased and the organic content decreased over this transition. The percentage of beach sand in the SCL's overlying the 1MT, 2MT, and $4 \mathrm{MT}$ horizons from core sites 21,15 , and 19 indicate a transport distance for the sand of approximately 1-2 km based on sand percentages of the sediments in the bay west of and adjacent to the sites (Peterson et al, 1984). The percent beach sand (less than 10\%) from the 1MT, 2MT, and 4MT horizons did reflect the bay sediments. The SCL's were considered tsunami deposits (Peterson and Darienzo, 1991). An additional sample from AB21 (4SCL above 


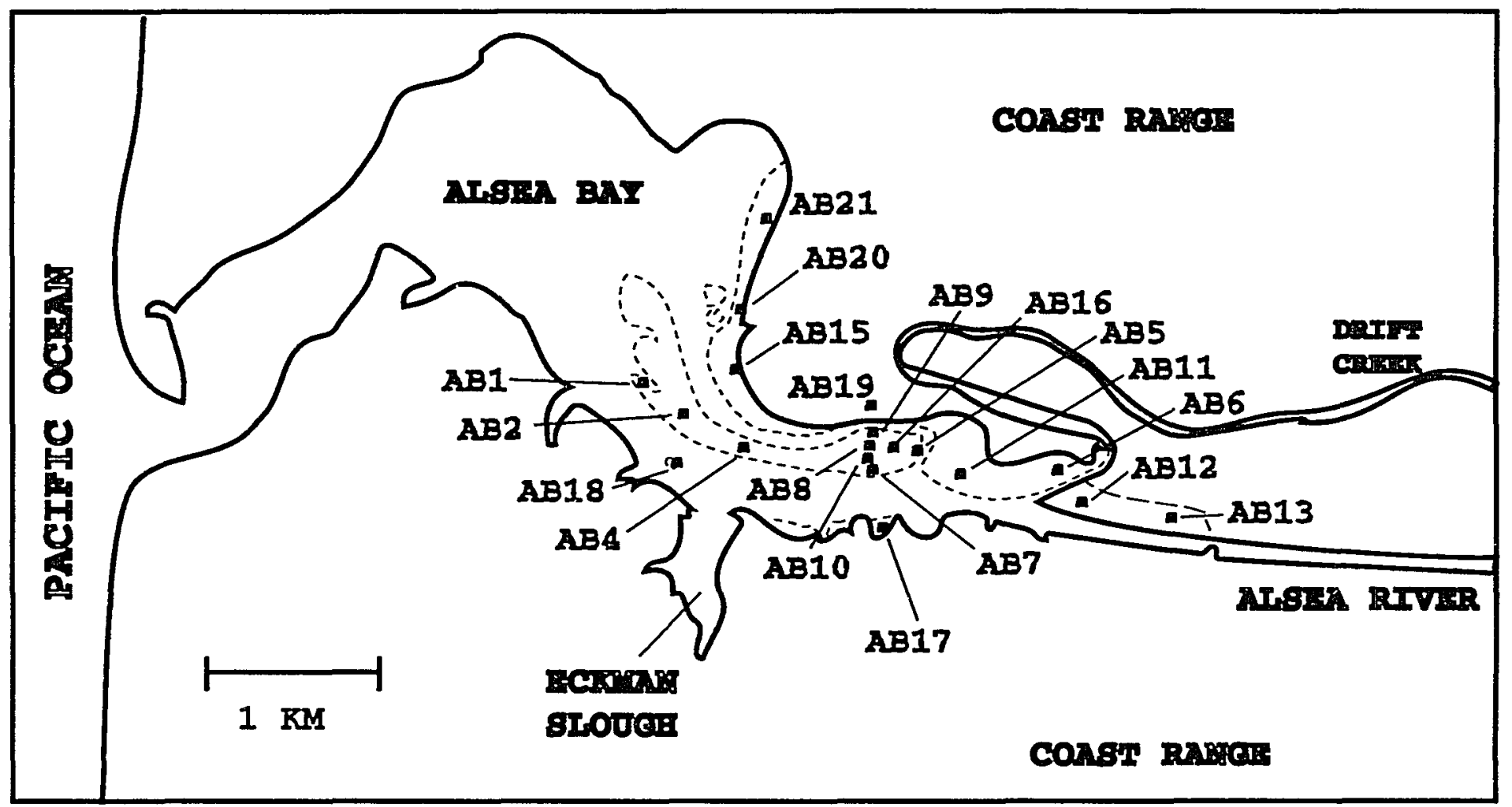

Figure 44. General setting and core site locations in the marshes of Alsea Bay. 


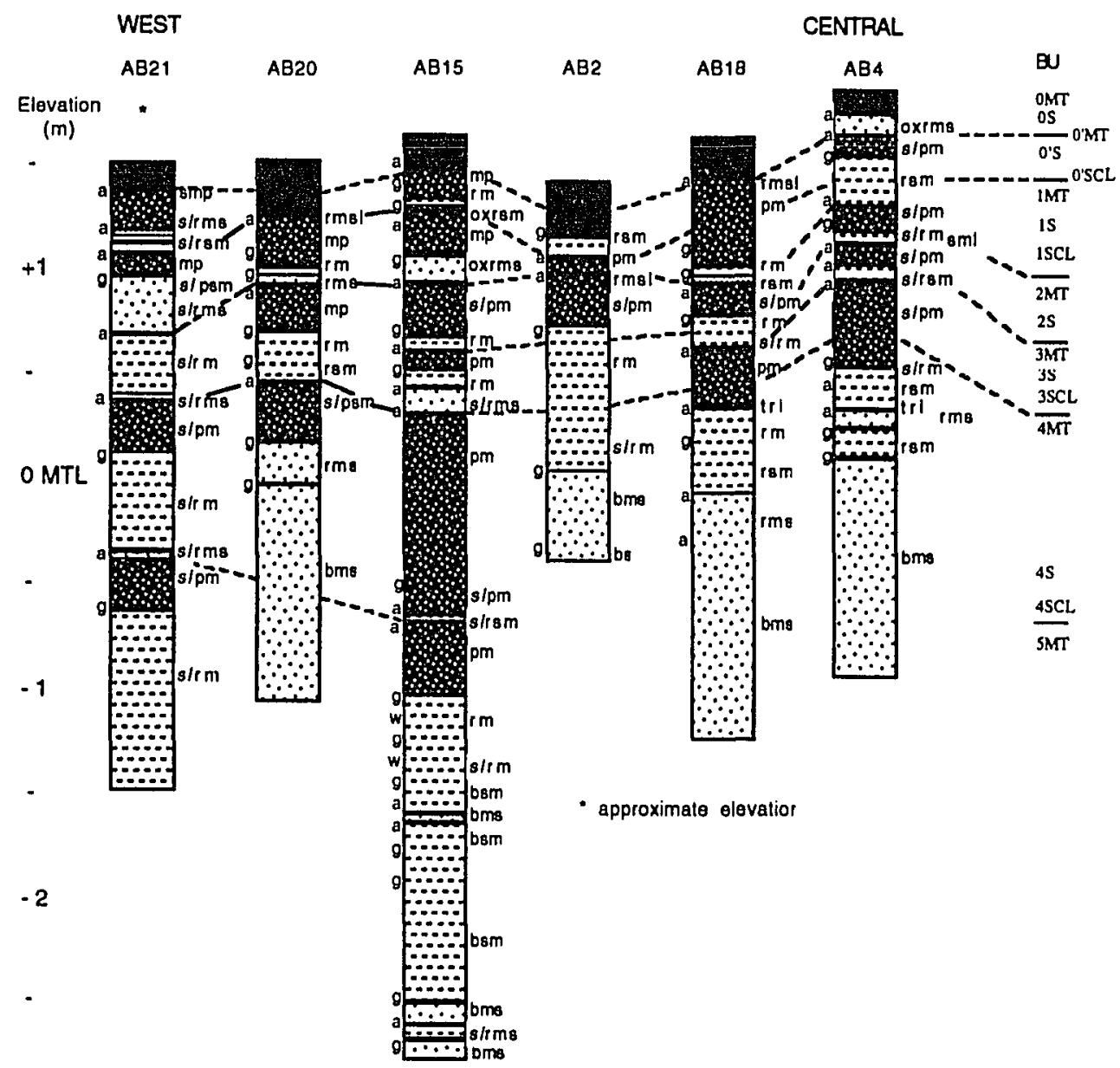

.3

Eiqure 45. Stratigraphy of the cores from the western section of the marsh system in Alsea Bay.

$5 \mathrm{MT}$ ) was analyzed for sand source and contained $8 \%$ beach sand, comparable to the percent beach sand in the bay adjacent to the site.

\section{Badiocarbon Ages}

The radiocarbon ages are summarized in Figure 48. All ages came from core AB9, except one. The 3MT horizon came from AB15 (Peterson and Darienzo, 1991). The sample from AB15 yielded a radiocarbon age of 


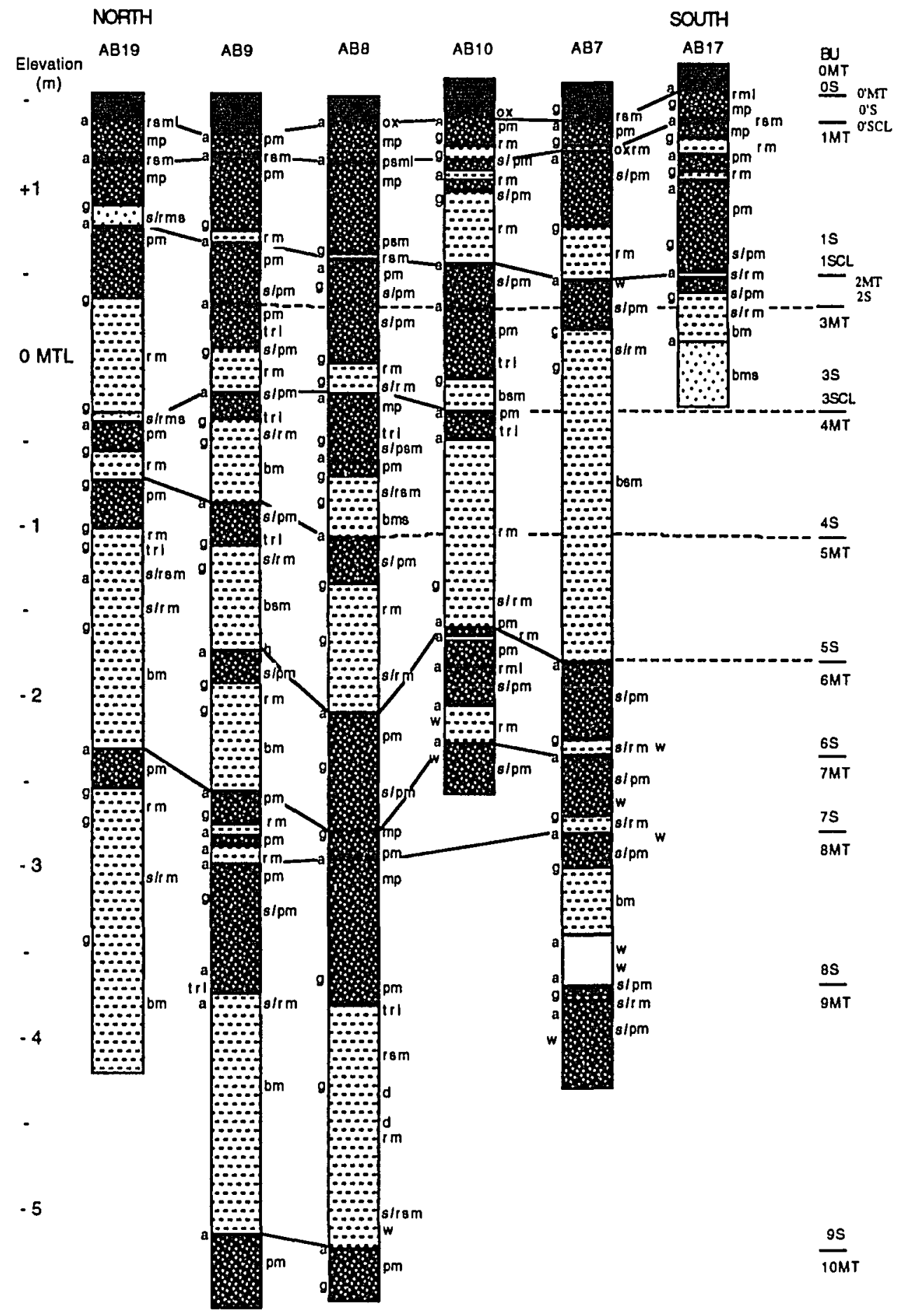

Figure 46. Stratigraphy of the cores from the central section of the marsh system in Alsea Bay. 


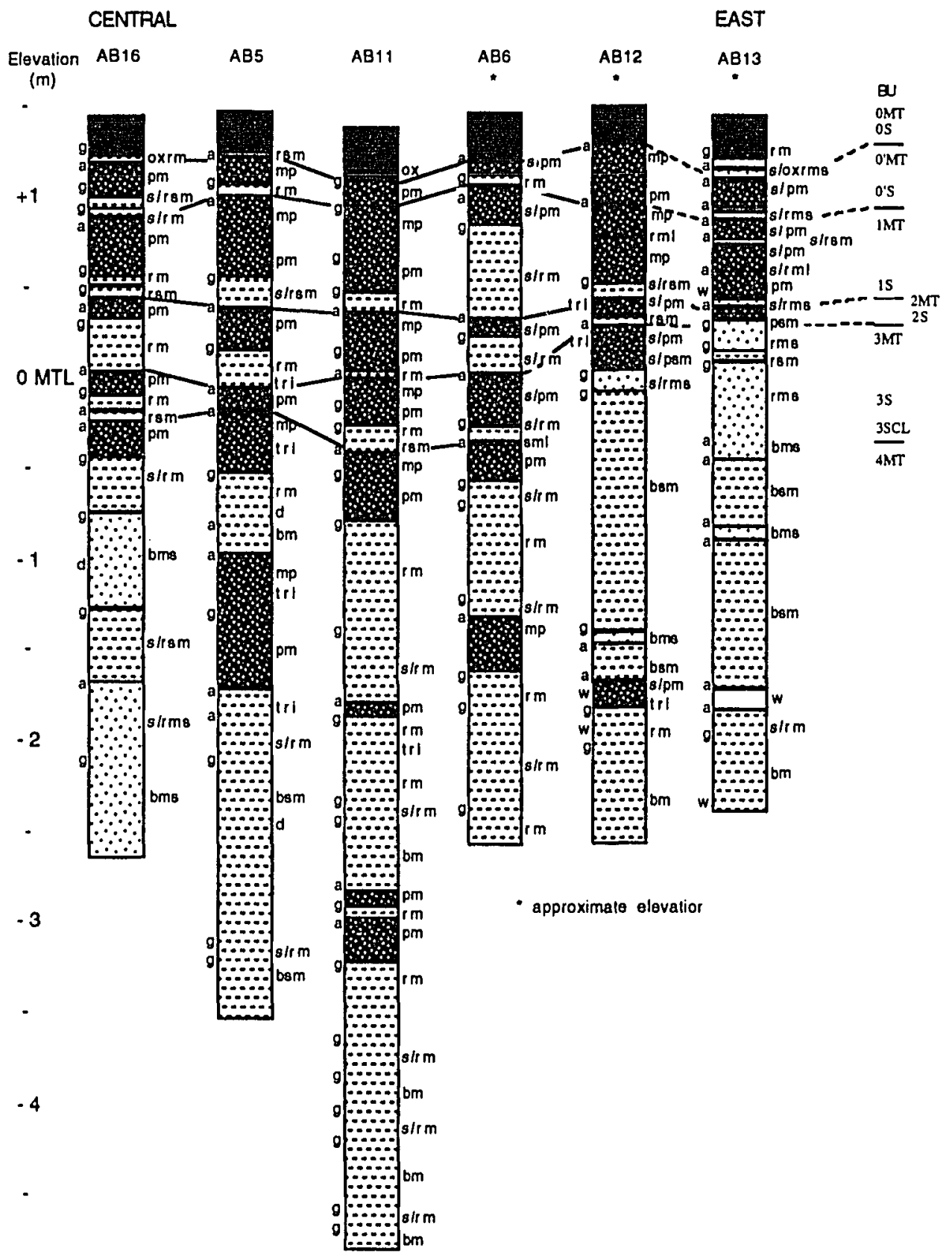

Eigure 47. Stratigraphy of the cores from the eastern section of the marsh system in Alsea Bay.

$1950 \pm 120$ RCYBP. This age is not consistent with the ages of the $2 M T$ and $4 M T$ । horizons from AB9. 


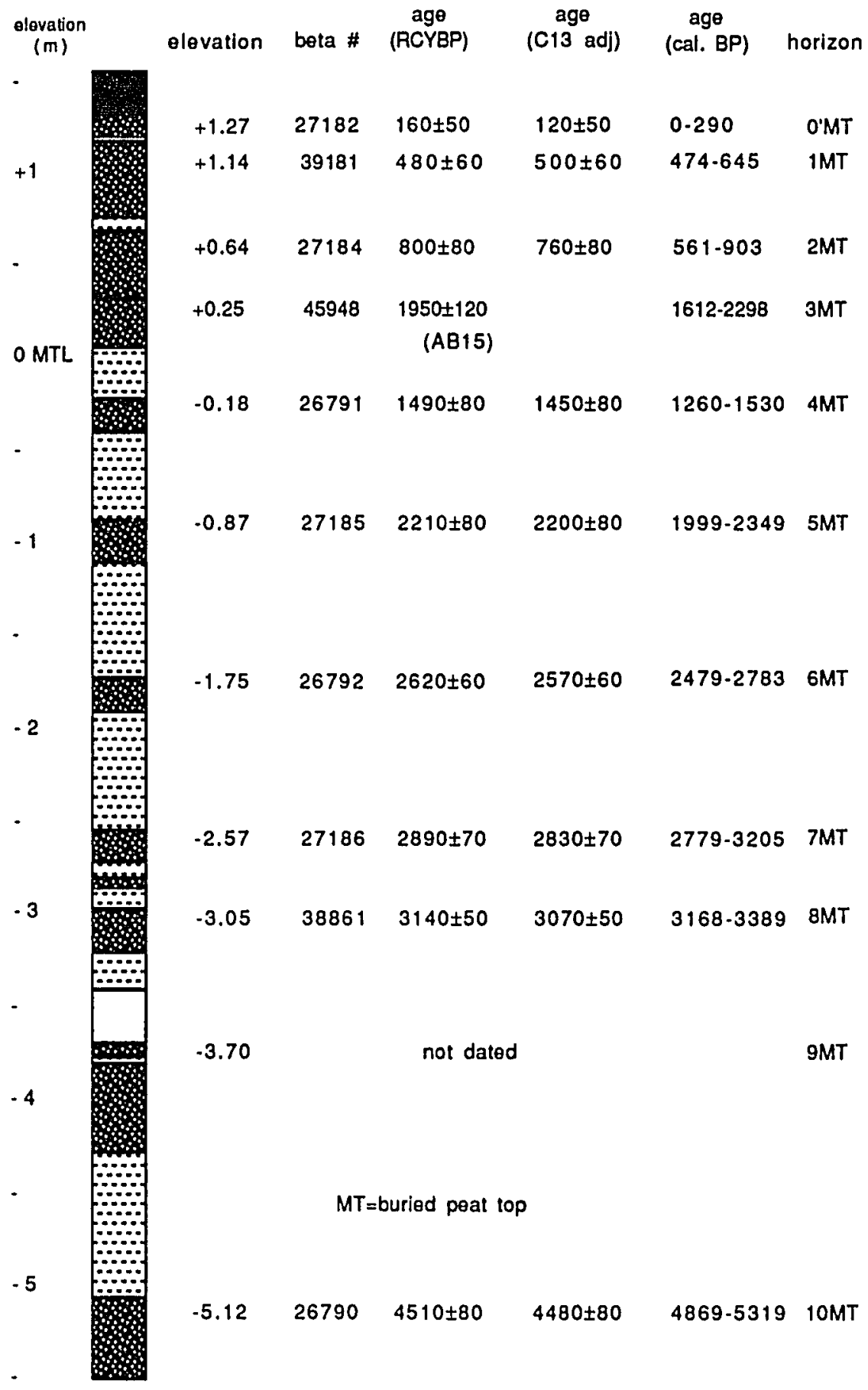

Figure 48. Radiocarbon ages of the buried peats from AB9. 


\section{DISCUSSION}

\section{COSEISMIC MARSH BURIAL}

This section summarizes the evidence for coseismic burial for the top six events identified in the Necanicum River, Nestucca Bay, Siletz Bay, and Yaquina Bay. Evidence for additional burial events identified in Netarts Bay and Alsea Bay are also discussed. Several criteria are used as evidence for coseismic peat burial. They are as follows: 1) There are abrupt contacts between organic-rich MT (peat top) horizons and organic-poor S horizons overlying it, indicating abrupt subsidence of the salt marsh, rather than gradual sea level rise where gradational contacts would be the rule. Peats usually develop through marsh plant growth and debris accumulation in contrast to a tidal flat environment where there is constant flushing of organic debris and very little plant growth because of increased tidal inundation. 2) Gradual contacts between MT and underlying $S$ horizons, indicating redevelopment of a marsh system after coseismic subsidence and burial. 3) There is an increase in percent sand in the anomalous SCL (sediment capping layer) horizon, indicating deposition of sand by mechanisms such as floods, storms or tsunamis. In contrast, there is a smaller percentage of sand in the peat (MT horizon) that underlies the SCL as well as in the lower organic sediment (S horizon) that overlies the SCL. This sand is deposited by normal (eolian or tidal) sedimentation processes on the marsh and tidal flat. In cases where marshes are adjacent to spits, the sand component in the MT horizon (high marsh peat) can be greater than the sand component of the $S$ horizon, because 
of the relative increase in eolian sands carried to the marsh as the marsh is removed from tidal influence (Darienzo and Peterson, 1990). 4) In riverdominated marsh systems there is a smaller percent sand in the MT than the $S$ horizon, indicative of a high marsh setting that's rarely inundated by tides and a' tidal flat setting that is constantly being inundated by tides. There is a greater potential for higher sand percentages because of this lower tidal elevation. This change in percent sand with changes in tidal elevation is documented at Alsea Bay (Peterson and Darienzo, 1991). In spit/lagoonal systems with no river input, the percent sand increases in the MT horizons, due to the increase of windblown sand reaching the marsh which decreases away' from the spit as documented at Netarts (Darienzo and Peterson, 1990). . 5) The first appearance of or increase in the percent beach sand component in the distinct anomalous sand layer (SCL) with respect to the MT and S horizons, would indicate a tsunami or storm surge carrying sediments upriver and not river flood deposits. Tsunami surges do resuspend sediments in the estuary and the tsunami deposit would reflect the sediment composition of the bay (Minoura and Nakaya, 1991). In Siletz Bay the sediment of the bay near the core sites on the spit is river-derived (Peterson et al, 1982). A tsunami surge would show river sand in the SCL and wind-blown (beach) sand in the MIT horizon. An SCL horizon, in which there is either an increase, first appearance or coarsening of the beach component in relation to the MT horizon, indicates either a storm or tsunami surge and is identified as positive-beach. An SCL horizon, in which there is a coarsening of the river component, indicates either flood deposition, lowering of base level, or a tsunami and is identified positive-river. An increase in beach sand component might indicate selective sorting rather than deposition by a tsunami. However, heavy mineral roundness, used to 
determine source, is not a function of grain size, a sorting parameter (Peterson et al, 1982). 6) Triglochin rhizomes in low organic sediments overlie well devgloped peats with remains of high marsh plants, such as Juncus and Potentilla, indicating a change from a high marsh to low or colonizing marsh. Triglochin rhizomes tend to be $10-20 \mathrm{~cm}$ below the subaerial portion of the plant and a rhizome less than $20 \mathrm{~cm}$ below a buried peat surface would indicate that the Triglochin plant is either within the MT horizon or in the overlying S horizon. This has implications for delineating the paleoenvironment. The plant within the top part of a peat would indicate low marsh, the plant in the middle of the peat would indicate high marsh, and the plant within lower organic sediments would indicate colonizing marsh. 7) A rapid transition from freshwater diatom assemblages in well developed peats (MT) to brackish/marine assemblages in overlying low organic sediments ( $S$ and $S C L$ ) is characteristic of a change from very high marsh, that is rarely inundated by tides, to lower marsh or tidal flat settings. Brackish/marine diatom assemblages above a freshwater peat can also be used to support a surge of water from the ocean (i.e., tsunami), in cases where subsidence to a tidal flat or lower marsh setting can not be delineated. 8) Spruce stumps or roots, that protrude from cutbanks and are connected to a soil (peat) horizon, are overlain by estuarine tidal flat sediments or marsh deposits. Spruce roots usually spread laterally and parallel to the surface. Any fossil spruce roots found would thus correspond to the MT horizon that it is protruding from and not a younger horizon. 9) Burial events are correlated between core sites located in different parts of the estuary. The marshes were not buried by storms, because storm surges would not bury the marshes with sediment in the upper estuary. Floods would not deposit sediments on the marshes in the lower estuary. Coseismic subsidence and burial is more likely to affect areas over 
10 's of $\mathrm{km}$ wide and 100's of km long (Peterson and Darienzo,1991). In studies done in Louisiana (Rejmanek et al, 1988) and Delaware (Stumpf, 1983), a hurricane and major storm deposited only a few $\mathrm{cm}$ of sediment and a few $\mathrm{mm}$ of silt, respectively, over a high marsh close to the source. In contrast, the sediments overlying buried peats in Oregon are fine sands as much as $10 \mathrm{~cm}$ thick and several $\mathrm{km}$ from their source (Peterson and Darienzo, 1991).

The mechanisms of burial for the peats identified in the bays will be identified using these criteria. To delineate paleoenvironments with respect to percent organics, the following arbitrary percent/environment system will be used: if peat is $>20 \%$ then the environment is considered high marsh, $>10 \%$ low marsh, $>5 \%$ colonizing marsh, and $<5 \%$ tidal flat (Darienzo and Peterson, 1990; Peterson and Darienzo, 1991). Diatom assemblages, macrofossils, and percent sand, will be used in conjunction with percent organics. Once the paleoenvironment is determined, then an elevation is assigned using elevations of the modern environments and amounts of subsidence are estimated.

Only the six most recent burial events in each bay will be discussed, because 1) all bays record at least six events, 2) preservation of peats decreases over time due to river migration making correlation more difficult for older deposits, and 3) any long-term settling problems that would cause correlation problems within and between bays are avoided. The evidence for coseismic burial for the top six events in each bay. The evidence is presented in detail in the following sections, but is summarized in Table IV. 
TABLE IV

SUMMARY OF EVIDENCE FOR COSEISMIC BURIAL EVENTS IN ALL BAYS

$\begin{array}{lllllll}\text { Event } & \text { Nec } & \text { Net } & \text { Nes } & \text { Sil } & \text { Yaq } & \text { Als } \\ 1 & 1-8 & 1-4,6-8 & 1-5 a, 6-8 & 1-4,8 & 1,2,4,8 & 1-5 a, 8 \\ 2 & 1-8 & 1-4 & 1-5 b, 8 & \begin{array}{l}1,2 a, 3- \\ 6,8\end{array} & 1,2 a, 6,8 & 1-5 a, 6,8 \\ 3 & \begin{array}{l}1-4,5 a \\ 6-8\end{array} & 1,2,8 & 1-5,8 & 1-3 a, 4,8 & 1,2 a, 3 a, 4 & 1,2,3 a, 8 \\ 4 & 1-4,8 & 1-4,5-8 & 1,2,6,8 & 1-6,8 & 1,2 & 1-5 a, 8 \\ 5 & 1-5 a & 1-4,6-8 & 1,2,4,5 a, & 1-5,7,8 & 1,2,3,4 & 1,2 a, 4,8 \\ & & & 6,8 & & & \\ 6 & 1-5 a, 7 & 1-4,7-8 & 1,2,8 & 1-4,8 & \begin{array}{l}1,2,3,4, \\ 5 b\end{array} & 1,2 a, 4,6, \\ & & & & & \end{array}$

\section{Evidence Key}

1 abrupt contact between MT and overlying SCL/S

2a Percent organic decrease from MT to overlying SCL/S

2b Percent organic increase from SCL/S to overlying MT

3a Percent sand increase from MT to overlying SCL/S

$3 \mathrm{~b} \quad$ Percent sand decrease from SCL/S to overlying MT

4 Distinct SCL

5a Positive-beach transition from MT to SCL/S

5b Positive-river transition from MT to SCL/S

$6 \quad$ Macrofossils (marsh plants, tree roots, shells)

7 Microfossils (diatoms)

8 Widespread extent of buried horizon

\section{Necanicum Biver}

The first burial event (1MT to $0 \mathrm{SCL}$ or $\mathrm{S}$ ) has the following coseismic burial criteria: 1) abrupt contacts between the 1MT and overlying OSCL or S horizon, 2) decrease in percent organics from the $1 \mathrm{MT}$ to $0 \mathrm{SCL}$ or $S$ horizon, with the percent changes ranging from $<1$ to $17 \%$ and increase (except Neawanna 5) from OS to OMT from $1-30 \%, 3$ ) increase in percent sand from the 
MT to SCL horizon from 4-12\%, decrease to the overlying S horizon from 6$31 \%$ and decrease from OS to OMT of 5-7\%, 4) transition (1MT to OSCL) from a freshwater diatom assemblage to a mixture of freshwater and brackish/marine diatoms at Neawanna 5, brackish and freshwater mix to a brackish, marine, and freshwater mix at Neawanna 7, freshwater to freshwater/minor brackish at Neawarina 2, alfreshwater to freshwater with minor marine at Neawanna 9, and a freshwater/minor brackish to brackish/minor freshwater at Neacoxie cutbank, 5) presence of a distinct $\mathrm{SCL}$ at core sites Neawanna 2, 3, 5, 7, 8, 9, and 10 and cutbanks 4 and 5,6 ) a positive-beach transition (increase in percent beach component) for Neawanna 7 and positive-river for Neawanna 5, and 7) widespread extent of the MT horizon in cores over a distance of 3 and possibly $4 \mathrm{~km}$ and the ability to trace (using tree-roots) the horizon in cutbanks over approximately one $\mathrm{km}$ to just downstream of Neawanna 7. Based on the presence of predominately freshwater diatom assemblages and in situ tree roots, the paleoenvironment of the $1 \mathrm{MT}$ horizon between Neacoxie and Neawanna cutbank 2 was probably lowland coastal forest, but still tidally influenced based on the brackish influence nearby at Neawanna 7. Due to the overall low percent organic change in the cores analyzed for loss on ignition and the lack of any noticeable change in diatom assemblages from 1MT to OS horizon, it does not appear that the 1MT horizon subsided to tidal flat, colonizing marsh or low marsh elevations. The difference between the modern elevation of a forested zone adjacent to a high marsh and a lower high marsh is at least 1 $\mathrm{m}$, based on surveys of modern marshes and adjacent coastal forests. Estimates of the elevation of a paleowetland forest are tenuous, but if we use the lower limit of the modern elevation of the forested zone as a paleoelevation and assume that subsidence reached lower high marsh levels based on 
percent organics, then estimates of coseismic displacement would be a minimum of one meter. Estimates of subsidence may be difficult to make in transitions from forest to high marsh settings. It appears that displacements were greater than $1.0 \mathrm{~m}$ based on tree roots, percent organics and diatom assemblages between 1MT and OS in cutbanks and cores Neawanna 2, 5 and 7. The increase in sand content, the increase in the beach component of the sand (Neawanna 7), and brackish/marine diatoms in the SCL versus the MT and $S$ horizons indicates a possible surge of water from a tsunami or storm, excluding river flooding as a mechanism of burial. The beach was not far east of its present location 450 years B.P. (Rankin, 1983), thus a storm surge as the mechanism of sand transport and deposition, that far up Neawanna Creek, seems unlikely. A tsunami with associated subsidence from an earthquake appears most plausible for the 1MT/1SCL/OS transition.

The 2MT to $1 \mathrm{SCL} / 1 \mathrm{~S}$ transition is characterized by 1) abrupt contacts at all core and cutbank locations, 2) a decrease in percent organics from $5-27 \%$ at Neawanna 1,2, and 7 but a slight increase at Neawanna 5, an increase from $1 S$ to $1 \mathrm{MT}$ of $1-34 \%$ at Neawanna 7 and 1,3 ) an increase in percent sand from MT to SCL of $1-35 \%$ and a decrease from SCL to the S horizon at Neawanna 5 of $17 \%$, a decrease in percent sand from $1 S$ to $1 \mathrm{MT}$ at Neawanna 7 of $26 \%, 4$ ) a significant diatom changel at Neawanna 7 from freshwater with lesser brackish/marine to brackish/ marine with lesser freshwater assemblages, 5) distinct SCL's at Neawanna 5 and 7 and cutbanks 1, 4, 5, and 6, 6) positivebeach transition at Neawanna 2, 5 and 7 (increase in percent beach component especially at Neawanna 2 and 5), and 7) correlation of the MT horizon in cores and cutbanks over distances of at least one $\mathrm{km}$. The SCL between cutbanks 5 and 6 is a weathered gravel that does not appear to have come from the beach 
side and could possibly be a deposit from a large debris flow that originated upstream in the Coast Range (S. Burns, personal communication, 1991). Large debris flows that would carry material from the steeper part of the Coast Range (over $1 \mathrm{~km}$ to the west) would be rare. Although mechanisms which would produce a flow and deposit of this magnitude can be non-seismic, earthquakes as a possible mechanism can not be discounted for this event. Nor could it be ignored for the preceding event ( $1 \mathrm{MT}$ to $0 \mathrm{~S}$ ) where the $\mathrm{OSCL}$ horizon of Neawanna 2 contained weathered gravel as well.

Based on the presence of freshwater diatoms and in situ tree roots in the 2MT horizon, the paleoenvironment was also probably low coastal forest but not as extensive as $1 \mathrm{MT}$ because of the presence of brackish/marine diatoms at Neawanna 5. At Neawanna 5 and 7 , the environment was probably salt marsh, but whether it was high or low marsh is not clear. An argument could be made for low marsh based on percent organics, but high percent sand tends to produce low organic contents regardless of the type of environment (core site N6 at Netarts in Darienzo and Peterson, 1990). The 2MT to $1 S$ elevational transition is estimated to be less than $1 \mathrm{~m}$, because of the lack of dramatic changes from the 2MT to $1 \mathrm{~S}$ horizon with respect to changes in percent organics and diatom assemblages at Neawanna 2, 5, and 7 and in the relative changes in organic content at the other sites. The 1SCL horizon had an increase in percent sand and an increase in beach component at Neawanna 5 and 7 , and an increase in brackish/marine diatoms at Neawanna 7 indicating a surge of water from the marine side This event was coseismic with displacements between 0.5 and $1.0 \mathrm{~m}$.

The 3MT/2SCL/2S transition is characterized by 1) abrupt contacts between the buried peat and overlying lower organic sediments, 2) percent 
organics decreased (2-17\%) from 3MT to 2S in Neawanna 2, 5 and 7,and increased (12-30\%) from 2S to $2 \mathrm{MT}$ in Neawanna 2 and 7 only, 3) the percent sand content increased (26-56\%) from 3MT to 2SCL/S and decreased (38$82 \%$ ) from the S/SCL layer to the overlying 2MT for Neawanna 2 and 7 only, 4) distinct SCL's at Neawanna 2, 6 and cutbank 7 and a high percent sand S horizon at Neawanna 5 and 7,5 ) a transition from freshwater to freshwater/brackish/marine mix at Neawanna 2 and a freshwater to freshwater/minor brackish at Neawanna 7,6) a positive-beach transition (increase in percent beach component at Neawanna 2, 5, and 7 and coarsening at 2 and 7), and 7) correlation of the event in cores over one kilometer. Minimal exposure in cutbanks was seen, because of the depth of the buried peat. Based on the dominance of freshwater diatoms in the 3MT horizon at all three sites and the tree root (spruce ?) in cutbank 7, the paleoenvironment was probably coastal wetland forest. The data from the $2 S$ horizon do not indicate a change to a tidal flat or low marsh setting, but most likely indicate a change to a high marsh or lower elevation forest. Because the overlying 2SCL/S horizon contained not only an increased percentage of sand, but brackish/marine diatoms and a higher and coarser beach sand component, the mechanism of transport was a tsunami. The cause of burial was coseismic subsidence with displacements between 0.5 and $1.0 \mathrm{~m}$.

The 4MT to 3SCL/S transition is characterized by 1) gradual but clear contacts at Neawanna 2, 5, and 6 and an abrupt contact at Neawanna 7,2) decrease in percent organics (2-24\%) and increase (1-7\%) from $3 S$ to $3 M T, 3)$ an increase $(5-41 \%)$ in percent sand from $4 \mathrm{MT}$ to $3 \mathrm{SCL}$ and a decrease (23\%) from $3 S C L$ to $3 S$ at Neawanna 2 and a decrease (7-43\%) from $3 S$ to $3 M T$ at Neawanna 5 and 7 only, 4) distinct SCL at Neawanna 2 and high percent sand 
$S$ horizons at Neawanna 5 and 7, and 5) correlation of the 4MT horizon in cores over a one kilometer distance. Based on the exclusive freshwater diatom assemblages in the $4 \mathrm{MT}$ horizon at sites 2,5 , and 7 , the paleoenvironment was probably either a very high brackish marsh, a freshwater marsh or perhaps a lowland forested wetland. There is no indication from diatoms or from percent organic changes that the environment of the $3 S$ horizon was different from the 4MT horizon, although the percent organic content decreased by $16 \%$ from 4MT to 3MT at Neawanna 7. The 3SCL/S horizon had increased percentages of sand compared to the 4MT and 3MT horizons except at Neawanna 2, but no significant diatom or beach component trends were noted. The mechanism of burial is questionable and if coseismic, displacements were less than $1.0 \mathrm{~m}$.

The $5 \mathrm{MT} / 4 \mathrm{~S}$ transition is characterized by 1) abrupt contacts between the peat and overlying lower organic deposits, 2) decrease in percent organics of 2 $9 \%$ and increase $(2-11 \%)$ in percent organics from $4 S$ to $4 M T, 3)$ increase in percent sand (8-29\%) from 5MT to 4SCL/S and decrease (7-10\%) from 4SCL/S to $4 M T, 4$ ) distinct SCL's at Neawanna 2 and 5, 5) no significant diatom trends, 6) positive-beach transition (increase in percent beach component) at Neawanna 2 and 5,7 ) correlation of the 5MT horizon between two cores $0.3 \mathrm{~km}$ apart. The paleoenvironment of 5MT is probably high marsh at Neawanna 2 and very high marsh or freshwater marsh at Neawanna 5 based on a brackish and freshwater mix at Neawanna 2 and freshwater diatoms at Neawanna 5. At Neawanna 5, the SCL's percent sand content increases dramatically and the beach sand component also increases supporting a tsunami mechanism of deposition. The percent organics of the $4 S$ horizons do not support a change to a low marsh, but to a lower freshwater or high brackish marsh setting. Coseismic subsidence was less than $1 \mathrm{~m}$. 
The $6 \mathrm{MT} / 5 \mathrm{SCL} / 5 \mathrm{~S}$ transition is characterized by 1) abrupt contacts, 2) a decrease (19-27) in percent organics and an increase (6-15) from the $5 S$ to the $5 \mathrm{MT}$ horizon, 3) an increase $(29-38 \%)$ in percent sand and a decrease $(23 \%)$ from $5 S C L$ to $5 S$ at Neawanna 2, and a decrease (5-10\%) from $5 S$ to $5 \mathrm{MT}, 4)$ a distinct SCL at Neawanna 2 and a minor one at Neawanna 5, 5) a significant increase in marine diatoms at Neawanna 2,6) a positive-beach transition at Neawanna 2, and 7) correlation of the 6MT horizon between Neawanna 2 and 5 a distance of $0.3 \mathrm{~km}$. The paleoenvironment of $6 \mathrm{MT}$ is high marsh based on diatom assemblages and there is a distinct SCL. The transition from 6MT to $5 \mathrm{~S}$ at Neawanna 2 appears to be from high marsh to upper low marsh based on changes in percent organics and would indicate an elevational change of between 0.5 and $1.0 \mathrm{~m}$. From the percent organics, marine diatoms and increased beach component, the burial event was coseismic with an associated tsunami.

In summary, there is strong support for coseismic subsidence for all six burial events except the 4MT/3S transition. The evidence suggests that amount of subsidence for each event was at least 0.5 to $1 \mathrm{~m}$. The upper limit of elevation of a coastal lowland forest can not be firmly established so coseismic displacements might have been greater.

Netarts Bay

Documentation for coseismic burial has been established for most of the events at Netarts Bay (Darienzo and Peterson, 1990). Three more burial events (2MT, 6MT, and 10MT) have been identified and more information has been gathered concerning the previously recorded events. The 2MT/1SCL/1S transition is well documented at Oyster Farm and Wee Willies only and is characterized by 1) abrupt contacts between the 2MT and 1SCL horizon, 2) 
reduction in percent organics $(<1-7)$ from the MT to $S$ horizon and increase (21\% at Oyster Farm) from the $1 \mathrm{~S}$ to $1 \mathrm{MT}$ horizon, 3) a dramatic change in sand percent from the $1 \mathrm{~S}$ to $1 \mathrm{SCL}$ to $2 \mathrm{MT}(<10 \%$ to $83 \%$ to $<10 \%$ ) horizons of both Oyster Farm and Wee Willies, 4) a distinct SCL, and 5) $100 \%$ beach sand in the sand of the SCL horizon. The 2MT/1SCL transition in the southern part of the bay is identified either as a sand laminae at the base but within the 1MT horizon, sand laminae within muds, or a sand layer between muds below the base of $1 \mathrm{MT}$. A storm surge, rather than tsunami, as a possible mechanism of burial can not be ruled out, because of the apparent low elevation of the paleomarsh. Winter storms and associated sand surges come from the southwest. The Wee Willies' site is in a protected area behind a Pleistocene terrace with an opening away from the expected direction of the surge. Distant tsunamis as a mechanism is also a possibility, because the 1964 Alaskan earthquake tsunami did scour the bottom of Netarts Bay. No studies after the Alaskan earthquake were conducted to see if the mobilized sand was deposited on muddy tidal flats or salt marsh surfaces anywhere in the bay. No distinct sand layer was identified in the top of the modern peats at any core sites. Another possible mechanism of deposition is a coseismic subsidence event in an adjacent segment with production of a tsunami that affected Netarts Bay. The location of the sand layer at the base of the peat horizon supports this hypothesis. Based on the SCL's large sand percent and its source, abrupt contacts between 2MT and 1SCL at Oyster Farm and Wee Willies, possible occurrence of the SCL throughout the bay at similar depths, and decrease in organics from $2 \mathrm{MT}$ to $1 \mathrm{SCL}$, coseismic subsidence as the mechanism of burial can not be ruled out. If coseismic, displacements within Netarts Bay were probably less than $1.0 \mathrm{~m}$ and perhaps less than $0.5 \mathrm{~m}$, because of minimal 
development of the 2MT horizon, indicating perhaps low or colonizing marsh, and small reductions in percent organics from the $2 \mathrm{MT}$ to 15 horizon. Analysis of adjacent bays is needed to clarify the burial mechanism for this event.

In contrast to the $2 \mathrm{MT} / 1 \mathrm{SCL}$ transition, the $6 \mathrm{MT} / 5 \mathrm{SCL} / 5 \mathrm{~S}$ transition is well documented throughout the bay and is characterized by 1) abrupt contacts between the $6 \mathrm{MT}$ and $5 \mathrm{SCL} 5 \mathrm{~S}$ horizons, 2) significant decrease in organics (e.g. 32 to $9 \%$ at N5A) from $6 \mathrm{MT}$ to 5 S horizon except for N7, 3) presence of an SCL at Oyster Farm and N7 with significantly higher sand percentages than above or below, 4) transition from a freshwater/brackish to brackish diatom assemblage, 5) $93-100 \%$ beach sand in the $5 \mathrm{SCL}$ horizon of Oyster Farm and N7, and 6) correlation at similar depths throughout the bay, with the exception of the sites on the southeastern side of the bay (N7 and N13) which are higher in elevation. The 6MT horizon might be higher at these locations owing to their location over a shallow Pleistocene terrace surface, although Oyster Farm is lower but also overlies a terrace. The mechanism of burial is coseismic with an estimate of subsidence greater than one meter based on data at N5A that indicates a high marsh to colonizing marsh or tidal flat transition.

The 10MT/9SCL/9S transition is recognizable at N5A, N10, and Oyster Farm and is characterized by 1) abrupt contacts, 2) distinct SCL at N5A that contains a significantly higher percentage of sand than 9S and 10MT, 3) substantial decrease in organic content from MT to $S$ horizon ( 20 to $4 \%$ at N5A), and 4) correlation of the burial event throughout the bay. The mechanism of burial is coseismic, based on the abrupt peat to barren mud transition and SCL horizon. The environment of the MT horizon was probably high marsh and the $S$ horizon was tidal flat. Subsidence estimates are one meter or greater. 
All transitions support coseismic subsidence (1.0-1.5 m displacement) except the 7MT/6S and 8MT/7S. The horizons (where present) contain freshwater diatoms assemblages at all core sites except N12, where the 7MT and $7 \mathrm{~S}$ horizons (8MT is not present) have brackish/marine diatom assemblages and at N7 where the 8MT horizon is freshwater, but the overlying sediments are brackish marine. The 7MT peat has a gradual contact with the overlying barren muds at all sites except N5A and a gradual diatom assemblage change from freshwater to brackish/marine documented at N5 and N11. This, along with no SCL, does not indicate abrupt coseismic subsidence for this transition. The 8MT to $7 \mathrm{~S}$ transition, although abrupt, has no SCL and is characterized by freshwater diatom assemblages, also indicating another mechanism of environmental change besides coseismic subsidence. The mechanisms of burial of the 7MT might be gradual subsidence, either eustatically and/or tectonically-controlled. The 8MT peat surface might have been ponded over most of the southern bay, as well as other parts of the bay (Oyster Farm area). The fine sediments of the $7 \mathrm{~S}$ horizon may have been deposited in the pond from the upland via creeks and eolian transport from dune sources. The $8 \mathrm{MT}$ horizon is also very thin compared to other MT horizons at Netarts that have freshwater diatom assemblages. Perhaps the area was uplifted rapidly from a tidal flat setting (as indicated by brackish diatoms in the $8 \mathrm{~S}$ horizon) to a very high marsh isolated from tidal influence, resulting in ponding. More detailed microfossil studies are needed to test these hypotheses.

Further evidence (plant macrofossils) to support rapid and thus coseismic subsidence for the 1MT and 4MT was gathered from the cutbank at Oyster Farm. Rhizomes of Juncus, a high marsh plant, were found at the top of both 
1MT and 4MT and the basal stem of Potentilla pacifica, an upper high marsh plant, was found at the top of $1 M T$. Immediately overlying the $1 M T$ and 4MT horizons were Triglochin rhizomes, a low marsh/tide flat colonizer, in low organic muds. A thin veneer $(1-2 \mathrm{~mm})$ of sand and spruce needles was overlying the $4 \mathrm{MT}$ horizon. A spruce stump was protruding from the cutbank of the 5MT horizon.

\section{Nestucca Bay}

The 1MT/OSCL/0S transition is documented well at the Nestucca Duck sites and is characterized by 1) abrupt contacts between the MT and SCL horizons, 2) decrease in percent organics $(27-10 \%)$ from MT to $S$ at Nestucca Duck 3 and a dramatic decrease in organics from a sandy muddy peat to a rooted mud at Nestucca Duck 1,3 ) an increase in percent sand (0-3 to $86 \%)$ from MT to SCL and a decrease in percent sand (86 to 4-14\%) from SCL to $S$, 4) presence of a distinct SCL, 5) positive-beach transition (increase in beach sand) at Nestucca Duck 1 and 3, and 6) correlation of the event at similar depths in three separate locations $0.3 \mathrm{~km}$ apart. The paleoenvironment of the MT horizon at Nestucca Duck was probably an upper high marsh based on brackish/marine diatom assemblages and peat thickness at Nestucca Duck 1. The paleoenvironment of $0 S$ was probably colonizing marsh owing to presence of Triglochin rhizomes, indicating an elevation change of between 1.0 and 1.5 $\mathrm{m}$. The rapid elevation change and presence of a high percent sand unit above the peat require coseismic subsidence as the mechanism of burial with estimates of subsidence between 1.0-1.5 m.

The $1 \mathrm{MT} / 0 \mathrm{~S}$ transition is also recognized at the Hurliman and Little Nestucca sites, but there is some uncertainty about this designation as discussed earlier. This transition is characterized by 1 ) abrupt contacts 
between $1 \mathrm{MT}$ and $\mathrm{OS}, 2$ ) decrease in percent organics (3-15\%) from $1 \mathrm{MT}$ to $0 \mathrm{~S}$ and an increase from OS to the modern marsh surface (20-27\%) at Hurliman 2 and Little Nestucca 4 and 5,3) an increase in percent sand from $1 \mathrm{MT}$ to $0 \mathrm{~S}$ at Little Nestucca 1 and 2, 4) a distinct SCL at Little Nestucca 1 and 2, 5) positivebeach transition (coarsening) as well as a negative-beach one (decrease of percent beach sand) at Little Nestucca 1 and a positive-beach (increase in beach sand) at Little Nestucca 2, and 6) presence of Triglochin rhizomes above the thick MT horizon at Little Nestucca 1. Correlation between the Hurliman 2 and Little Nestucca 4 and 5 sites is tenuous and is only supported by similar depths below the surface. There might be a possible correlation between Nestucca Duck, Little Nestucca 1 and 2 and Nestucca 1 based on similar depths and the presence of a distinct sand layer over the 1MT horizon. The paleoenvironment of the 1MT horizon at Little Nestucca 5 and Hurliman 2 is high marsh and either very high marsh or freshwater marsh/coastal forest, respectively, based on diatoms and organic content. The OS horizon is most likely a marsh horizon from the percent organics and percent sand, thus the elevation change between the two horizons is not more than $1 \mathrm{~m}$. However, if the 1MT horizon was a forested zone differences could be greater at Hurliman. The paleoenvironment at Little Nestucca 1 appears to be a transition from a high marsh (from diatoms and peat thickness) to low, but not colonizing, marsh (Triglochin rhizomes above the peat top). This event is a coseismic burial with subsidence estimates of at least 0.5-1.0 m.

The $2 \mathrm{MT} / 1 \mathrm{SCL} / 1 \mathrm{~S}$ transition is characterized by 1) abrupt contacts between the 2MT and 1SCL/S horizons, 2) a decrease in percent organics (12$17 \%$ ) from $2 \mathrm{MT}$ to $1 \mathrm{~S}$ and an increase $(20 \%)$ from $1 \mathrm{~S}$ to $1 \mathrm{MT}, 3)$ an increase in percent sand from $2 \mathrm{MT}$ to $1 \mathrm{SCL}$ of $26 \%$ and a decrease from 1SCL to $1 \mathrm{~S}$ of 
$24 \%$ at Little Nestucca 5, 4) a distinct SCL horizon at Little Nestucca 5, although only river-positive, 5) no diatom trends, and 6) a possible correlation between the Hurliman sites and Little Nestucca 5 based on similar depths. The paleoenvironment of the 2MT horizon was high marsh based on diatom assemblages and percent organics and the paleoenvironment of the 15 horizon was probably colonizing marsh or tidal flat at Hurliman and lower high marsh at Little Nestucca 5 interpreted from diatom and organic content. Owing to the abrupt contacts and the percent organic changes, the mechanism of burial of the 2MT horizon for Little Nestucca 5 and Hurliman 2 was coseismic with displacements between 0.5 and $1.5 \mathrm{~m}$.

The 3MT/2SCL/2S transition is characterized by 1) abrupt contacts between 3MT and the overlying 2SCL/2S horizon, 2) decrease in percent organics (9-32\%) from $3 M T$ to $2 S$ and an increase (15-17\%) from $2 S$ to $2 M T, 3)$ increase in percent sand from $3 \mathrm{MT}$ to $2 \mathrm{SCL}$ of $45 \%$ and a decrease of $49 \%$ from 2SCL to $2 S$ at Little Nestucca 5,4 ) no diatom trends (all brackish/marine), 5) distinct SCL at Little Nestucca 5 and Nestucca 2, 6) slight positive-beach at Nestucca 2 (increase in beach sand from 0 to $4 \%$ ) and a positive-river trend at Little Nestucca 5,7$)$ possible correlation between the Hurliman sites and Little Nestucca 4 and 5 based on depth, and 8 ) a dry peat top ( $10 \mathrm{~cm}$ thick) at Little Nestucca 5. Based on the percent organics and sand and the diatom assemblages, the paleoenvironment of 3MT is probably high marsh at Hurliman 2. The Little Nestucca 5 3MT horizon, although a similar paleoenvironment, might have been higher in elevation because of the presence of the dry top. The $2 S$ horizon is slightly rooted and probably signifies an upper tidal flat/colonizing marsh setting. From the abrupt contact and change in organic 
content, the mechanism of burial at Hurliman and Little Nestucca 4 and 5 is coseismic with subsidence between 0.5 and $1.5 \mathrm{~m}$.

The 4MT/3S horizon is characterized by 1) abrupt contacts at the Hurliman sites and gradual although distinct contacts at Little Nestucca 5 and Nestucca 2,2 ) a decrease in organics of $3-16 \%$ with an increase of $36 \%$ from $3 S$ to $3 M T$ at Little Nestucca 5, 3) a decrease in organic content at Hurliman 1 and 3 and Nestucca 2 with an apparent increase from 3S to 3MT at Hurliman 3 and Nestucca 2, 4) the presence of Triglochin rhizomes approximately $20 \mathrm{~cm}$ above 4MT at Little Nestucca 5, and 5) possible widespread correlation of the event over a distance of six kilometers based on similar depths below the surface. The plant fossils (brackish diatoms and Triglochin) and organic content indicate high marsh and upper low marsh as the paleoenvironments of the 4MT and $3 S$ horizon, respectively. Coseismic subsidence is the mechanism of burial with estimates of vertical displacements between 0.5 and $1.0 \mathrm{~m}$.

The 5MT/4S transition is characterized by 1) abrupt contacts between the $5 \mathrm{MT}$ and overlying $4 \mathrm{~S}$ horizon, 2) decrease in percent organics (18-34\%) from $5 \mathrm{MT}$ to $4 \mathrm{~S}$ at Hurliman 2 and 3 and Little Nestucca 5 and an increase (33\%) from 4S to 4MT at Hurliman 2 and an apparent increase at Nestucca 2, 3) a distinct SCL at Little Nestucca 1, 4) freshwrater/brackish to brackish/marine diatom assemblages at Little Nestucca 5 and a freshwater to brackish/marine at Hurliman 2,5) no significant percent sand changes but a positive-beach transition (increase in percent beach component and coarsening) at Little Nestucca 1,6) the presence of a Triglochin rhizome above the 5MT horizon at Hurliman 2 and Little Nestucca 1, and 7) possible correlation between Hurliman 2 and the Little Nestucca sites based on depth. The paleoenvironment of 5MT at both Hurliman and Little Nestucca 5 is probably upper high marsh based on 
percent organics and diatom assemblages. From percent organics, the $4 \mathrm{~S}$ horizon is probably a lower high marsh at Little Nestucca 5 and a low marsh or colonizing marsh at Hurliman 2. The transition at Little Nestucca is probably from high marsh to colonizing marsh. From the abrupt contacts, percent organic changes, and Triglochin, the mechanism of burial is coseismic with subsidence estimates of 0.5-1 m for Little Nestucca 5 and 1.0-1.5 for Hurliman 2 and Little Nestucca 1.

The characteristics of the 6MT/5S transition are 1) abrupt contacts for most sites, 2) decrease (10-17\%) in percent organics and increase (23-30\%) from $5 \mathrm{~S}$ to $5 \mathrm{MT}$, and 3) correlation between the Hurliman 2 and Little Nestucca 5 sites using radiocarbon ages. The paleoenvironment of the 6MT horizon is probably upper high marsh based on organic content, diatoms, and thickness of the horizon. The 5S paleoenvironment is probably high marsh at Hurliman and low marsh at Little Nestucca 5 based on organic content. From abrupt contacts, changes in organic content, and widespread extent of the event, the mechanism of burial was coseismic with estimates of subsidence between 0.5 and $1.0 \mathrm{~m}$.

In summary, the mechanism of burial for all events is coseismic owing to abrupt contacts, changes in organic content, the stratigraphic location of Triglochin rhizomes, and similarity between the number of events and their depths below the surface over a distance of $6 \mathrm{~km}$, indicating the event was probably widespread.

\section{Siletz Bay}

The 1MT/OSCL/OS transition is characterized by 1) abrupt contacts between $1 \mathrm{MT}$ and OSCL, 2) decrease (3-4\%) in \% organics from $1 \mathrm{MT}$ to $0 \mathrm{~S}$ and an increase (11-27\%) from OS to OMT, 3) an increase in percent sand (79\%) from $1 \mathrm{MT}$ to $\mathrm{OSCL}$ and decrease $(31 \%)$ from OSCL to OMT at Salishan House, 
4) distinct SCL horizon, 5) possible correlation between the spit and Millport sites based on radiocarbon ages and depth. The paleoenvironment was upper low marsh at both Salishan House and Millport 1 based on percent organics and thickness of the MT horizon. The OS horizon would also be considered low marsh but slightly lower in elevation. However, conclusive proof is lacking for paleoenvironmental reconstructions at this site. Nevertheless, the mechanism of burial is either coseismic subsidence with an associated tsunami or the sand was deposited by a storm or distant tsunami. The extent of the OSCL along the spit is at least $0.7 \mathrm{~km}$, indicating a massive breach, if storm related. There has been no historical evidence of a distant tsunami breaching a spit in the Pacific Northwest, although a tsunami from an adjacent earthquake may be much stronger. A coseismic mechanism of burial, with estimates of displacement less than $1.0 \mathrm{~m}$, cannot be ruled out.

The 2MT/1SCL/1S horizon is characterized by 1) an abrupt contact between 2MT and 1SCL/1S, 2) a decrease in organic content from 2MT to $1 S$ at Siletz Spit, Salishan Spit, and Alder core sites, 3) an increase (41-72\%) in percent sand from 2MT to 1SCL/S at Salishan House and Millport 1 and decrease in percent sand $(7 \%)$ from $1 S$ to $1 \mathrm{MT}$ at Millport 1,4$)$ the presence of a distinct SCL, 5) beach-positive transition (coarsening of beach component) from 2MT to 1SCL at Salishan House and a river-positive at Alder and Millport $2,5)$ presence of Triglochin rhizomes immediately above the $2 \mathrm{MT}$ horizon at Salishan House, Salishan Spit, and Alder, and 6) very good correlation between the spit sites but weak correlation with the Millport and Alder sites. The paleoenvironment of the 2MT horizon is probably high marsh based on the organic contents and thickness of peat at all three spit sites. The $1 \mathrm{~S}$ horizon paleoenvironment is low marsh owing to the presence of Triglochin and the low 
organic content in the Siletz Spit core. Based on macrofossils, distinct SCL's, percent sand and organic content changes and the positive-beach transition, the mechanism of burial is coseismic with subsidence of at least $0.5 \mathrm{~m}$ if 2MT was lower high marsh and greater than $1.0 \mathrm{~m}$ if it was upper high marsh.

The 3MT/2S transition is characterized by 1) abrupt contacts, 2) decrease (4-7\%) in percent organics from $3 M T$ to $2 S$ and an increase of $9 \%$ from $2 S$ to 2MT at Salishan House, 3) a decrease (16\%) in percent sand at Salishan House but an increase of $27 \%$ at Millport 1 from 3MT to $2 S$ and an increase (25\%) from 2S to 2MT at Salishan House, 4) no distinct SCL except above Millport 1,5 ) the sand in the SCL at Millport 1 is all river, and 6) good correlation between the spit and Millport sites based on depth. The paleoenvironment of 3MT is most likely low marsh based on percent organics and thickness of the peaty layer. In contrast, the paleoenvironment of the $2 S$ horizon is colonizing marsh or tidal flat. Based on abrupt contacts, changes in organic content, and widespread correlation, the mechanism of burial is coseismic with estimates of subsidence of at least $0.5 \mathrm{~m}$.

The 4MT/3SCL/3S transition is characterized by 1) abrupt contacts between $4 \mathrm{MT}$ and $3 S \mathrm{CL}, 2)$ a decrease $(2-7 \%)$ in percent organics from $4 \mathrm{MT}$ to $3 S$ and an increase from $3 S$ to $3 M T$ of $4 \%, 3)$ an increase $(50-81 \%)$ in $\%$ sand from $4 \mathrm{MT}$ to $3 S \mathrm{CL}$, a decrease (20-74\%) from $3 S C L$ to $3 S$, and a decrease from $3 S$ to $3 M T$ of $28 \%$ at Millport 1, but an increase of $5 \%$ at Salishan House, 4) a distinct SCL, 5) beach-positive transition (slight increase in beach influence and coarsening of beach component) from $4 \mathrm{MT}$ to $3 \mathrm{SCL}$ at Salishan House and a river-positive transition at Millport 1 and 2,6) a change from a mixed brackish assemblage to an assemblage with only Paralia sulcata, a tidal flat species, at Salishan House, 7) the presence of Triglochin rhizomes above the SCL horizon 
and within the 4MT horizon at Salishan House and Millport 1, and 8) very good correlation between the spit and Millport sites based on depth and the SCL. The paleoenvironment of the MT horizon is probably low marsh based on organic content, Triglochin within the peat, and peat thickness. Owing to the presence of Triglochin within low organic sandy muds, the 35 horizon paleoenvironment is probably colonizing marsh. However, the rhizome is 20 cm below 3MT with the potential of the above ground part to be within the 3MT horizon. Based on changes in organic content, the beach-positive trend, the relatively thick $S$ horizon, and the location of the Triglochin rhizome $30 \mathrm{~cm}$ above the top of the buried peat, the mechanism of burial is coseismic with subsidence estimates of at least 0.5 and perhaps greater than $1.0 \mathrm{~m}$.

The $5 \mathrm{MT} / 4 \mathrm{SCL} / 4 \mathrm{~S}$ transition is characterized by 1) abrupt contacts between $5 \mathrm{MT}$ and 4SCL, 2) a decrease (7-10\%) in percent organics from $5 \mathrm{MT}$ to $4 \mathrm{~S}$ and an increase (1-2\%) from $4 \mathrm{~S}$ to $4 \mathrm{MT}, 3)$ an increase $(47-65 \%)$ in percent sand from $5 \mathrm{MT}$ to $4 \mathrm{SCL}$, a decrease (63-66\%) from $4 \mathrm{SCL}$ to $4 \mathrm{~S}$, and a slight increase at Salishan House from 35 to $4 \mathrm{MT}, 4)$ a change from brackish (MT) to brackish/marine (SCL/S) at Millport 1,5) a distinct SCL, 6) negativebeach transition (increase in river component) at Salishan House, a positivebeach transition (coarsening) at Millport 2, and a positive-river at Millport 1 from $5 \mathrm{MT}$ to $4 \mathrm{SCL}$, and 7) very good correlation between the spit and Millport sites. The presence of an increased river component in the SCL horizon would not necessarily exclude a tsunami and therefore coseismic subsidence as the mechanism of burial. The sand content of the bay near the core sites has predominately river sand (Peterson et al, 1984) and a tsunami surge within the bay would scour and deposit the river-dominated sand on the subsided marsh surface. The paleoenvironment of the most developed MT horizon (Salishan 
House) is probably high marsh based on percent organics and thickness of peat. The mechanism of burial is coseismic based on abrupt contacts, change in organic content, and presence of distinct SCL. Estimates of subsidence are at least 0.5-1.0 m but less than $1.5 \mathrm{~m}$.

The $6 \mathrm{MT} / 5 \mathrm{SCL} / 5 \mathrm{~S}$ transition is characterized by 1) abrupt contacts between $6 \mathrm{MT}$ and $5 \mathrm{SCL} / 5 \mathrm{~S}, 2)$ a decrease $(5 \%)$ in percent organics from $6 \mathrm{MT}$ to $5 \mathrm{~S}$ at Millport 1 only and an increase (8-10\%) from $5 \mathrm{~S}$ to $5 \mathrm{MT}, 3$ ) an increase (5-40\%) from $6 \mathrm{MT}$ to $5 \mathrm{SCL}$ and decrease from $5 \mathrm{SCL}$ to $5 \mathrm{~S} / 5 \mathrm{MT}$ at Salishan House and from 6MT to $5 S$ at Millport 1,4 ) a distinct SCL at Salishan House, and 5) good correlation between the spit and Millport sites based on depth. The paleoenvironment of $6 \mathrm{MT}$ is probably low marsh for the most developed horizon, whereas the $5 \mathrm{~S}$ horizon is colonizing or tide flat. The mechanism of burial is coseismic, based on widespread correlation, and estimates of subsidence are at least $0.5 \mathrm{~m}$.

The mechanism of burial for the six events in Siletz bay is coseismic based on widespread correlations and presence of distinct SCL's and Triglochin overlying buried peats. Estimates of subsidence were $0.5-1.0 \mathrm{~m}$ for all the events. A burial event recorded at Millport 1 between 4MT and 5MT is not considered a coseismic event because it is not identified at other locations and the sandy mud overlying the peat contains very fine river sand, unlike other SCLS layers which tend to be coarser.

\section{Yaquina Bay}

In Yaquina Bay, buried peats were found in a few widely separated locations. There were also no distinguishing characteristics of the burial units which would aid in correlation over 18 river kilometers between core sites. Correlations (burial unit designations) were thus based on relative surface 
elevations, depth of buried peats, and radiocarbon ages. In addition, a horizon (O'MT) was identified that had no obvious counterparts in bays to the north. This horizon tends to be shallow (less than $50 \mathrm{~cm}$ below the surface) and is less than 200 years B.P., not only in Yaquina Bay, but in Alsea and South Slough (Figure 1) as well.

The O'MT/OSCL/OS transition is characterized by 1) a thin $(2-3 \mathrm{~cm})$ organic horizon at cutbanks $A$ and $B$ with protruding tree roots at cutbank $A$ only, 2) two very thin (1 cm) and closely spaced (6 cm apart) organic layers with abrupt contacts above and below each overlain by $6 \mathrm{~cm}$ of lower organic muddy sands at cutbank $\mathrm{C}, 3$ ) an increase (72\%) in percent sand from O'MT to OSCL and a decrease $(71 \%)$ from $O S C L$ to $O S$ at Hatfield in the lower estuary, and 4 ) a significant increase in marine diatoms from O'MT to OSCL at Hatfield. It would be difficult to correlate horizons between the upper and lower reaches of the estuary, but based on depth and radiocarbon ages it does not seem unreasonable that the O'MT horizons are time-stratigraphic. The Oysterville sites in cutbank and core reveal two burial events and they are possibly 0'MT and $1 \mathrm{MT}$ horizons based on depth. The modern environment is high marsh with Potentilla pacifica and Deschampsia caespitosa, whereas trees are growing above the Slack cutbanks. This would mean the Oysterville sites are lower in elevation. It would seem reasonable then that the horizons could also be 1MT and 2MT. However, O'MT was recognized in both Hatfield cores and the Slack cutbanks, therefore it will be assumed that the horizons are 0'MT and 1MT at Oysterville. The O'MT/OS transition is characterized by 1) a decrease $(8 \%)$ in percent organics from O'MT to OS and an increase (31\%) from OS to OMT and 2) a change from forest (tree roots protruding from cutbank to a modern high marsh at the surface of cutbank 4. But only brackish diatoms were 
found in this horizon in the nearby core, questioning whether the roots are in situ and/or associated with this buried horizon. The O'MT horizon is presumed missing at the Slack and Conser cores based on relative stratigraphic position and radiocarbon ages. The thin organic layers in the Slack cutbanks could also be interpreted in another way. A thin organic layer in a river bank could indicate a flood or slack water deposit and not a soil horizon that was coseismically subsided and buried (S. Burns, personal communication, 1991). Nevertheless, the abrupt contacts, changes in organic and sand (Hatfield only) content, possible correlation between all three areas of the estuary (a distance of 10 $\mathrm{km})$, and perhaps an environmental change from forest to tidal flat in Slack cutbank A could indicate a coseismic mechanism of burial. However, the stratigraphic evidence and correlation potential is weak, thus coseismic subsidence as the mechanism of burial is suspect. If coseismic, estimates of subsidence would range from $>1.0 \mathrm{~m}$ for the Slack cutbanks, 0.5 to $1.0 \mathrm{~m}$ for Oysterville and less than $0.5 \mathrm{~m}$ for Hatfield.

The 1MT/0S transition in Yaquina Bay is characterized in the Slack cutbank by relatively abrupt contacts between peaty, tree-rooted horizons and overlying lower organic muds. The Slack cutbank $1 \mathrm{MT}$ horizons are thicker (5$12 \mathrm{~cm}$ ) than the 0'MT horizon (2-3) discussed above. Cutbank $C$ is still only 1 $\mathrm{cm}$, but in this case has no overlying sand. At Oysterville, it is characterized by 1) a decrease (4\%) in percent organics from $1 M T$ to 0 'S and an increase from O'S to O'MT, 2) in cutbanks, transition from a tree-rooted horizon to a low organic mud in cutbanks 1, 3, and 4, and 3) a distinct SCL in Oysterville 4 and Oysterville cutbank 4 . Once again, the diatom assemblages are brackish at Oysterville, which contradicts a forested paleoenvironment. This transition is not identified at the Hatfield and Slack sites, because of differences in 
radiocarbon ages and elevations, but is identified at the Conser sites based on mean tidal elevation and a decrease in percent organic content of $15 \%$ from the $1 \mathrm{MT}$ to $0 \mathrm{~S}$ horizon. The paleoenvironment of the sediments in the cutbank was perhaps coastal wetland forest, because of the presence of in situ tree roots associated with a relatively thick organic layer. Based on abrupt contacts, in situ tree roots covered with low organic muds and possible correlation between Oysterville and Slack cutbanks (a distance of $8 \mathrm{~km}$ ), the mechanism of burial is coseismic. Subsidence estimates for the Slack cutbanks and Oysterville sites would be 1.0-1.5 $\mathrm{m}$ and less for Oysterville if the environment was marsh instead of forest.

The 2MT/1S transition is only recognized in the upper reaches of the estuary at the Slack cutbank and Conser, Toledo and Blind core sites and is characterized by 1) abrupt contacts, 2) decrease in organic content, 3) widespread extent of burial event (over $4 \mathrm{~km}$ distance), and 4) an $8 \mathrm{~cm}$ soil horizon with tree roots overlain by low organic mud. The paleoenvironment of the 2MT was probably wetland forest from the cutbank, which would support, along with areal extent, coseismic subsidence as the mechanism of burial. Subsidence estimates would be 1.0 to $1.5 \mathrm{~m}$.

The 3MT/2SCL/2S transition was identified at the Hatfield, Slack, . . Conser, Toledo and Blind sites and is characterized by 1) abrupt contacts, 2) decrease in percent organics of $7-13 \%$ from $3 M T$ to $2 S$ at Hatfield, a decrease $(7 \%)$ in organic content from $3 M T$ to $2 S$ at Conser, and a decrease in organic content at the other sites, 3) a distinct SCL at Hatfield and Slack 1 and 5, 4) an increase in sand content (19\%) at Slack 1 and Hatfield $(40 \%), 5)$ a slight increase in marine diatoms at Hatfield, and 6) widespread extent of the burial event over a distance of $11 \mathrm{~km}$. The paleoenvironment of 3MT for the Hatfield 
and Slack sites is low marsh or colonizing marsh if the Triglochin rhizomes found at Hatfield are in 3MT. However, the rhizomes may have been injected from above the horizon, indicating presence of the colonizer in the $2 S$ horizon instead. For the other sites the paleoenvironment might have been lower high marsh to low marsh. The $2 S$ horizon was probably colonizing marsh or tidal flat based on organic content. Based on widespread extent of the event, decrease in organics and presence of a distinct SCL at Hatfield and Slack, the evidence suggests burial by coseismic subsidence with estimates of subsidence of at least $0.5 \mathrm{~m}$.

The 4MT/3S transition is found at Conser and Slack and is characterized by 1) abrupt contacts, 2) decrease (4\%) in percent organics from $4 M T$ to $3 S$ at Slack with an increase from $3 S$ to $3 M T$ of $13 \%$, and 3) a decrease in organic content at Conser. The paleoenvironment of the 4MT horizon appears to be upper low to lower high marsh at Slack and the 3S horizon colonizing marsh or tidal flat. Although the evidence is weak, the mechanism of burial is coseismic based on the abrupt contacts and decrease in organics, with subsidence estimates of at least $0.5 \mathrm{~m}$.

The 5MT/4S transition occurs at the Slack site only and is characterized by 1) abrupt contacts, 2) a decrease in percent organics of $4 \%$ from $5 \mathrm{MT}$ to $4 \mathrm{~S}$ and an increase $(8 \%)$ from 4 S to $4 \mathrm{MT}$ at Slack 1,3$)$ an increase in sand $(9 \%)$ from $5 \mathrm{MT}$ to $4 \mathrm{~S}$ and a decrease (21\%) from $4 \mathrm{~S}$ to $4 \mathrm{MT}$, and 4 ) a distinct sandy laminae overlying the 5MT horizon at Slack 1 and 5. The paleoenvironment of the 5MT and 4S horizons are low marsh and tidal flat, respectively. Although the evidence is weak, the mechanism of burial is coseismic, based on organic changes, abrupt contacts, and presence of sand laminae overlying the peat. Estimate of subsidence is less than $1.0 \mathrm{~m}$. 
The $6 \mathrm{MT} / 5 \mathrm{~S}$ transition is only found at the Slack sites and is characterized by 1) abrupt contacts at Slack 1 and 5,2 ) decrease in organics of $12 \%$ from $6 \mathrm{MT}$ to $5 \mathrm{~S}$ and an increase of $4 \%$ from $5 S$ to $5 \mathrm{MT}$ at Slack 1,3 ) an increase $(59 \%)$ in percent sand from $6 \mathrm{MT}$ to $5 \mathrm{~S}$ and a decresae of $54 \%$ from $5 \mathrm{~S}$ to $5 \mathrm{MT}$, and 4) a distinct SCL and a river-positive transition at Slack 1. The paleoenvironment of the 6MT and $5 S$ horizons are low marsh and tidal flat, respectively. Although the evidence is weak, it appears that the mechanism of burial is coseismic because of abrupt contacts and change in organic and sand content. Subsidence estimate is greater than $0.5 \mathrm{~m}$.

In summary, the seven burial events described all appear to be coseismic in nature, based on contacts and widespread extent of the burial units. Even though correlations might be suspect, a shift up or down in burial unit designations would still argue for widespread and thus coseismic burial, specifically for the events above 4MT. Modern marsh development in the Yaquina estuary is widespread, however buried peats are not as well developed as those in Alsea Bay and Siletz Bay. This might be a function of low fluvial sediment supply preventing high marsh development prior to the next burial event. The burial and reestablishment of forests at the Slack cutbank may be due to its upper estuarine location and greater sediment supply, however Oysterville also has buried tree roots and the sediment supply is much smaller. Overall, the evidence to support estimates of subsidence in the upper and central estuary is not strong, because of the lack of a diagnostic macro-or microfossil record (i.e. no Triglochin rhizomes in the $\mathrm{S}$ horizon above a treerooted zone). Nonetheless, estimates are always between 0.5 and $1.5 \mathrm{~m}$. 
Alsea Bay

Evidence for coseismic subsidence for most burial events at Alsea has been discussed in detail in Peterson and Darienzo (1991). However, burial unit designations were changed with respect to the 0'MT horizon and correlations between core sites were adjusted. The 0'MT-6MT horizons will be discussed with respect to these changes.

The 0'MT/OS transition is characterized by 1) abrupt contacts, 2) a decrease $(7-10 \%)$ in percent organics in two out of three core sites analyzed and a $2 \%$ increase in the other, 3) presence of a distinct SCL over six of the core sites, and 4) widespread correlation throughout the bay (a distance of 3-4 $\mathrm{km})$. No significant beach sand component $(<5 \%)$ was found in the SCL of AB4, indicating that the sand came from the nearby tidal flat or river. The paleoenvironment is probably high marsh based on the high organic content $(>37 \%)$ of the horizon. Because of abrupt contacts and widespread extent of the burial event, the mechanism of burial is coseismic with estimates of subsidence less than $1.0 \mathrm{~m}$.

The 1MT/0'SCL/0'S and $2 \mathrm{MT} / 1 \mathrm{SCL} / 1 \mathrm{~S}$ transitions have been discussed by Peterson and Darienzo (1991). Convincing evidence for coseismic burial and associated tsunami has been documented. Subsidence estimates for the 1MT/0'S and 2MT/1S transitions are $<0.5 \mathrm{~m}$ and 0.5-1.0 m, respectively.

The $3 \mathrm{MT} / 2 \mathrm{~S}$ transition is found at most sites and is characterized by 1) abrupt contacts, 2) a decrease in organic content at all sites except AB8 and an increase from 2S to $2 \mathrm{MT}$ at all sites, 3) a significant increase $(26 \%)$ in percent sand content from $3 M T$ to $3 S$ at AB12 only, 4) no distinct SCL's, 5) widespread correlation throughout the bay. The paleoenvironment of the 3MT horizon was mostly low marsh, because of the relatively low organic content and the 
presence of Triglochin rhizomes within the peat and $>10 \mathrm{~cm}$ below the MT surface at AB9. Since the above ground portion of the Triglochin plant could be up to $20 \mathrm{~cm}$ above the rhizome, the rhizome might be associated with 2S. The paleoenvironment of the $2 S$ horizon is either colonizing marsh (Triglochin rhizome above $3 M T$ at $A B 5$ and $<10 \mathrm{~cm}$ below it at $A B 12)$ or tidal flat. The mechanism of burial is coseismic, because of the abrupt contacts, change in organic content, and widespread extent of the event. Estimates of subsidence are $<1.0 \mathrm{~m}$.

The mechanism of burial for the 4MT/3SCL/3S transition has been identified as coseismic by Peterson and Darienzo (1991). Minimum estimates of subsidence range from $0.5 \mathrm{~m}$ to $1.0 \mathrm{~m}$.

The 5MT/4SCL/4S is recognized in five or possibly six (AB5) core sites and is characterized by 1) abrupt contacts, 2) significant changes in organic content, 3) presence of distinct SCL's at AB15 and AB21, and 4) possible correlation between core sites over one $\mathrm{km}$ apart. The paleoenvironment of the $5 \mathrm{MT}$ horizon is probably upper low to lower high marsh based on relatively low organic content and presence of Triglochin rhizomes within the peat more than $20 \mathrm{~cm}$ below the buried peat surface. In general, the $4 S$ horizon is most likely tidal flat or colonizing marsh based on relative organic content and thickness of peat. The evidence suggests that the mechanism of burial is coseismic with estimates of subsidence no less than 0.5 to $1.0 \mathrm{~m}$.

The 6MT/5S transition is characterized by 1) abrupt contacts, 2) a decrease in organic content from 12 to $4 \%$ at AB8 and significant decreases at the other sites, 3) presence of shell fragments immediately above the buried peat at $A B 9$, indicating a change from marsh to tidal flat, and 4) possible correlation of the horizon between core sites over two km apart. Based on this 
data, the paleoenvironment rapidly changed from low or high marsh to tidal flat. Therefore, the event is coseismic with subsidence estimates of at least $1.0 \mathrm{~m}$.

\section{SYNCHRONEITY OF EVENTS}

The criteria used to determine synchroneity of coseismic events between bays includes number of coseismic burial events, depth of burial events below the surface, radiocarbon ages, estimates of subsidence, degree of peat development, and presence of distinct sediment capping layers. No subsidence estimate trends were noted for the individual events between bays, other than they were all between 0.5 and $1.5 \mathrm{~m}$. Correlation between bays will take into consideration only burial events $1 M T-6 M T$, although the $0{ }^{\prime} M T$ event will be discussed briefly.

Each bay records six coseismic events within the top $3.0 \mathrm{~m}$ in the last 2600 RCYBP (radiocarbon years before present) except Alsea (3.3) and Yaquina (2780 RCYBP) and five events within the top $2.6 \mathrm{~m}$ in the last 2200 years (except Yaquina 2570 years). If 4MT at Neawanna is not considered a coseismic event, then Neawanna would have five events within $2.60 \mathrm{~m}$ in 2000 years, which would still be consistent with the other bays. The depth to the top of the buried peat for the last six events is very consistent between bays as shown in Figure 49. As shown in Table $V$, the depth to $1 \mathrm{MT}$ ranges from $0.40-$ $0.57 \mathrm{~m}$ (except Yaquina), to 2MT 0.67-0.90 m (except Yaquina), to 3MT 0.921.32, to 4MT 1.56-1.82 m, to 5MT 1.93-2.46 m, and to 6MT 2.63-3.30 m (excluding Hurliman 2).

If the fourth buried peat at Neawanna is not coseismic, then the 4MT range of coseismically buried peats would be 1.56-1.93 and the 5MT range 1.96-2.63. The $6 \mathrm{MT}$ depth at Hurliman is excluded because of long-term 


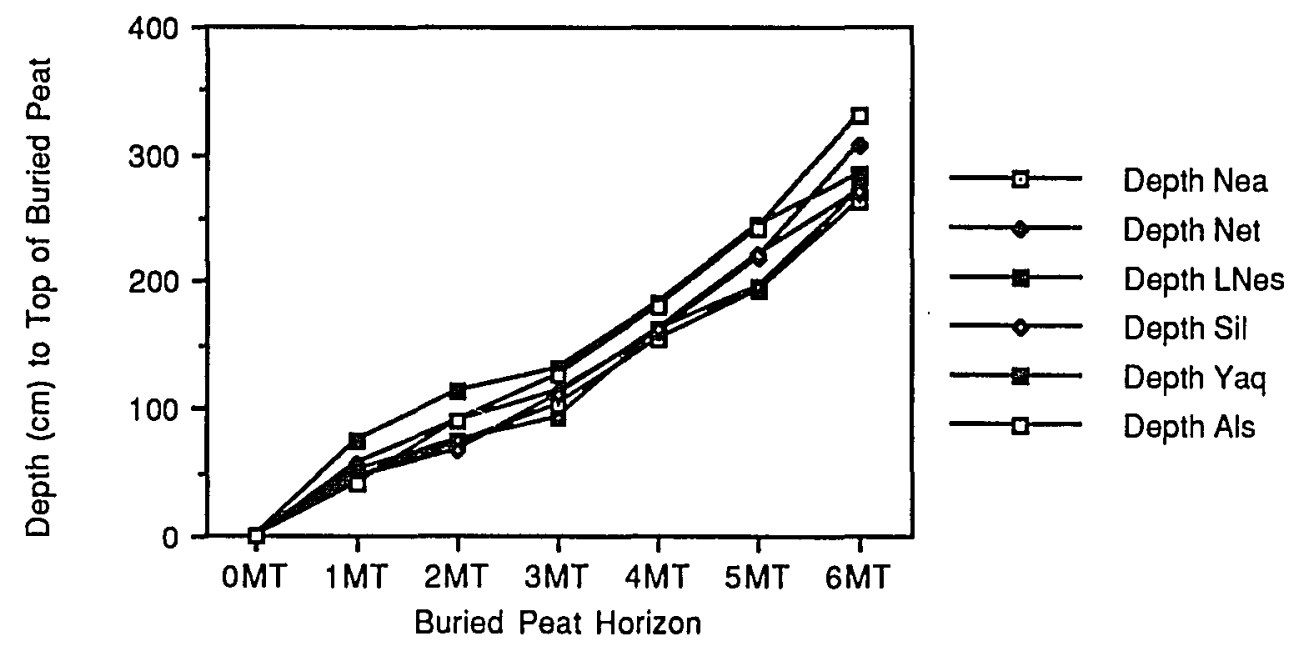

Figure 49. Plot of the depth to the top of the buried peat vs. burial horizon for each bay studied.

\section{TABLE V}

RANGES OF DEPTH TO THE TOP OF THE BURIED PEAT HORIZONS FOR ALL BAYS

\begin{tabular}{ccc} 
Burial_Horizon & Ranges $(\mathrm{cm})$ & \multicolumn{2}{c}{ Ranges $(\mathrm{cm})$} \\
O'MT & $27-39$ & \\
(exclude Yaquina) & \\
1MT & $40-75$ & $40-57$ \\
2MT & $67-114$ & $67-90$ \\
3MT & $92-132$ & \\
4MT & $156-182$ & \\
5MT & $193-246$ & \\
6MT & $263-330$ &
\end{tabular}

settling, which might be a factor in other bays especially below 5MT. The depth to the $0^{\prime} \mathrm{MT}$ horizon ranges between 0.27 and $0.39 \mathrm{~cm}$ (including South Slough).

The range of radiocarbon ages for the horizons are 140-160 RCYBP (0'MT, including South Slough), 270-550 (1MT), 350-800 (2MT, with 2 bays not dated), 1100-1460 (3MT with 1 bay not dated), 1370-1680 (4MT with 1 bay not dated) or 1490-1670 if Neawanna is also not included, 1690-2570 for all bays 
or 1690-2210 without Yaquina (5MT), and 2000-2780 (6MT) for all bays or 2550-2620 if Yaquina and Neawanna are excluded (Table VI). Neawanna might possibly have recorded only five events within 2000 years, thus allowing for better age comparisons between bays for that event. The 5MT age in Yaquina Bay is anomalous when compared to the other bays. Perhaps the age is representative of the 6th coseismic event. Since the stratigraphy of the Slack cores and cutbanks were combined due to an older age for the top most event at Slack 1 , the numbering of burial events may be incorrect. An event might be missing, which is not surprising considering the low sediment yield of the Yaquina River. The issue of whether the number of events or the ages are wrong might not be resolvable at the present time. Another possible adjustment in burial events is at Siletz Bay. If $1 \mathrm{MT}$ in Siletz Bay is actually a nonseismic/distant tsunami spit breach, then the 2MT would be 1MT. This is not unreasonable, because correlation with Millport would still be possible from ages of and depths to the peat top. In addition, the 2nd burial event would be considered missing, because of good correlation of the 3MT horizon between Salishan and Millport. With this adjustment the age range for 1 MT would be 350-550 years and for 2MT 660-800 years. The depth to the 1MT would also change $(40-67 \mathrm{~m})$. This interpretation would thus remove the age overlap for $1 \mathrm{MT}$ and 2MT. Regardless of proposed adjustments in horizon designations in the individual horizons, the similarities suggest 6 separate coseismic events in northern Oregon.

Distinct tsunami-deposited sandy capping layers (SCL) are present over the topmost buried peat (1MT) in all bays except Yaquina and over the fourth (4MT) in all bays except Yaquina and Nestucca. In contrast, a distinct SCL is absent over the 3rd buried peat (3MT) in four and possibly five of the bays. 
TABLE VI RADIOCARBON AGE (RCYBP) RANGES FOR THE BURIED PEATS FOR ALL
BAYS

\begin{tabular}{|c|c|c|c|}
\hline Burial Horizon & Age Ranges & $\begin{array}{l}\text { Aqe Rances } \\
\text { (excludes } \\
\text { Yaquina) }\end{array}$ & $\begin{array}{l}\text { Age Ranges } \\
\text { (excludes } \\
\text { Neawanna) }\end{array}$ \\
\hline $\begin{array}{c}\text { O'MT } \\
\text { (3 bays only) }\end{array}$ & $\begin{array}{l}140-160 \\
\text { (includes South } \\
\text { Slough) }\end{array}$ & & \\
\hline $\begin{array}{c}1 \mathrm{MT} \\
2 \mathrm{MT} \\
\text { (4 of } 6 \text { bays) }\end{array}$ & $\begin{array}{l}270-550 \\
350-800 \\
660-800 \\
\text { (exclude Siletz) }\end{array}$ & & \\
\hline $\begin{array}{c}\text { 3MT } \\
\text { (5 of } 6 \text { bays) }\end{array}$ & $1100-1460$ & & \\
\hline $\begin{array}{c}4 M T \\
\text { (5 of } 6 \text { bays) }\end{array}$ & $1370-1680$ & & $1490-1680$ \\
\hline $\begin{array}{c}5 \mathrm{MT} \\
\text { (5 of } 6 \text { bays) }\end{array}$ & $1690-2570$ & $1690-2210$ & \\
\hline $6 \mathrm{MT}$ & $2000-2780$ & $2000-2620$ & $\begin{array}{l}2550-2620 \\
\text { (also excludes } \\
\text { Yaquina) }\end{array}$ \\
\hline
\end{tabular}

When considering only Alsea, Siletz and Netarts Bay, the top four coseismically buried peats (1MT-4MT) have SCL's, except for the 3rd. The SCL is also absent over the third peat in Nestucca Bay. In addition, the 3MT horizon tended to be less well-cleveloped in Netarts Bay and Siletz and relatively indistinct at Alsea Bay.

Wendy Grant of the U.S. Geological Survey identified 4 coseismic burial events at Nehalem and Salmon (personal communication, 1991)(Figure 1 and 50). The events and ages at Nehalem were within the top $2.5 \mathrm{~m}$ and 1700 RCYBP, respectively. The 2MT event is probably missing at Nehalem, based on minimal development of that horizon at Netarts. The events and ages at 


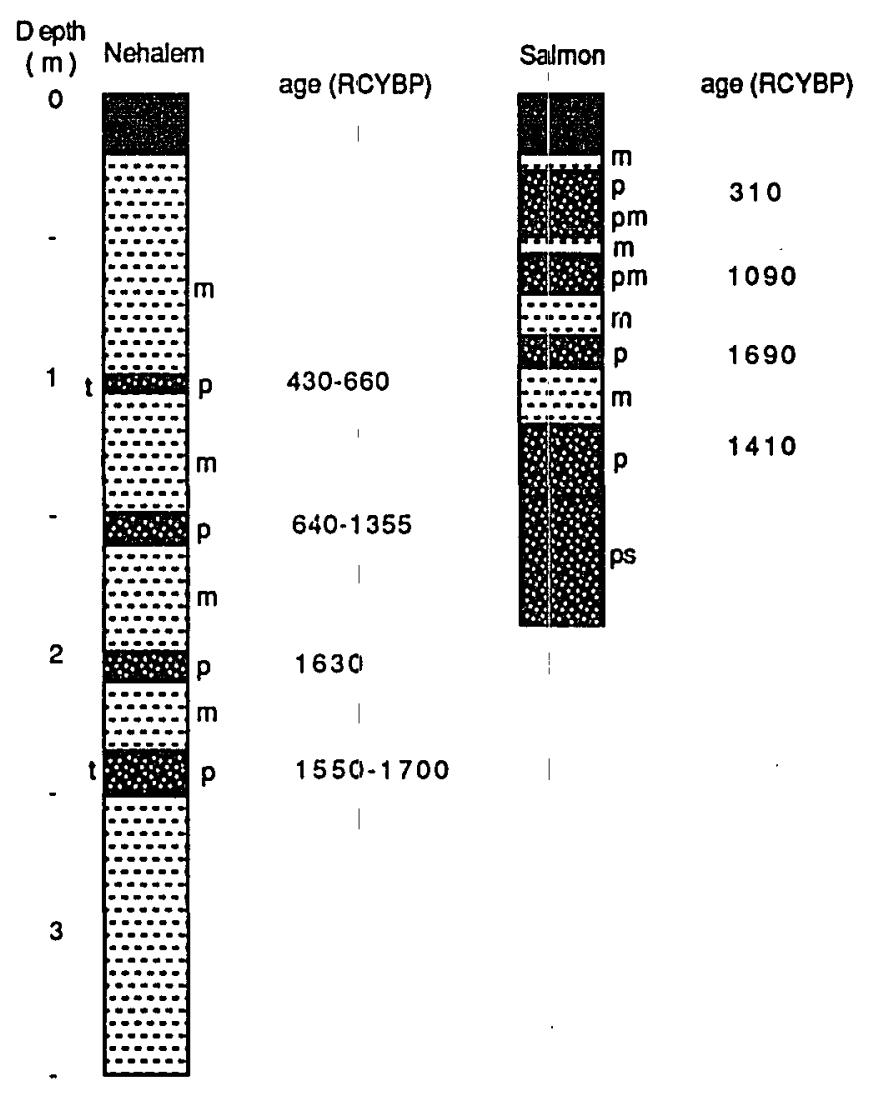

Eigure 50. Stratigraphy and radiocarbon ages of typical cutbank locations from Nehalem and Salmon (modified from Grant, personal communication, 1991).

Salmon were within the top $1.2 \mathrm{~m}$ and 1410 years and event two might also be absent or not recognized (Figure 50). The depths to the peat tops at Nehalem and Salmon are not consistent with the depths' in the six bays studied.

However, the top four events at Salmon are consistent with the degree of peat development for the 1MT, 3MT, 4MT and 5MT horizons at Netarts. That is, the 2nd buried peat at Salmon (3MT at Netarts) is weakly developed while the others have stronger development. Although the stratigraphic record at Nehalem and Salmon has differences, it is not incompatible with the records in the other bays. 
The 1MT burial event appears to be the most consistent and clearly represented event in all the bays, including Nehalem and Salmon, with respect to various criteria. From discussion of the similarities between bays, synchroneity between Necanicum and Alsea Bay for all six coseismic events is not out of the question and is especially strong for not only the 1MT but the 3MT, 4MT and 5MT burial events as well. The 6MT event would at least be synchronous between Netarts Bay and Alsea Bay. Because of the limited evidence of the 2MT event at Netarts, and possible absence of the event at Siletz, Salmon, and Nehalem, synchroneity of this event between Alsea and Necanicum is questionable. An alternative to synchroneity of events between Alsea and Necanicum is segmentation. Segmentation is when a locked subduction zone ruptures in two segments, producing great earthquakes of lesser coastline extent and magnitude. Although segmentation can not be ruled out, the presence of tsunami-deposited sand immediately above several buried peats and the absence of tsunami-deposited sand within the peat deposits, indicating that no sand from a tsunami generated by an adjacent great earthquake was deposited on the marsh surface at Alsea, Siletz, Netarts, Nestucca, and Necanicum, argue against segmentation. However, a case could be made for a segment boundary between Yaquina and Siletz if the O'MT burial event is considered coseismic, because no evidence of this event is found above the 1MT horizon in any bays north of Yaquina. A possible exception is Siletz Bay. If the 2MT is missing at Siletz and the 1MT event is O'MT instead, a segment boundary for the O'MT event would be extended to Siletz Bay. This change is supported by the fact that no buried peats in Siletz had radiocarbon ages between 600-800 RCYBP and by the lack of any buried peats at the Millport sites between 1MT and 3MT. 2MT could also have been 
more than one coseismic event with a possible segment boundary between Siletz and Necanicum. The 2MT event is not well documented in the bays between Siletz and Necanicum and the event at Netarts is identified by the presence of tsunami-deposited sand at the base of a buried peat, supporting an adjacent rupture and tsunami. Interestingly, a seismic segment boundary has been postulated just north of Siletz Bay by Spence (1989)(Figure 1). In summary, the evidence for synchroneity between Alsea Bay and Neawanna for the 1MT, 3MT, 4MT, 5MT events and between Alsea Bay and Netarts Bay for the 6MT event is strong (Figure 51). In contrast, the O'MT event and perhaps the 2MT event document evidence for segmentation.

Synchroneity of events could possibly extend north into southwestern Washington. Based on radiocarbon ages and similar peat development, three events recorded in Grays Harbor and Willapa Bay, Washington are comparable to the 1MT, 3MT and 4MT events of this study (Atwater, 1987). Atwater (personal communication, 1991) has found well-developed peats similar to the $1 M T$ and 4MT horizons with 1 (this study's 3MT) and possibly 2 (this study's 2MT) weakly developed horizons in between. Extension of synchroneity to Grays Harbor would add approximately $110 \mathrm{~km}$ to the rupture length (Figure 1).

\section{PALEOMAGNITUDES}

Coseismic mechanisms of marsh burial and synchroneity of these burial events between the bays studied have been reasonably established for all events except 2MT. Given a potential rupture width of $90 \mathrm{~km}$, based on widths of historical great earthquakes elsewhere and dislocation models for the Cascadia subduction zone (Rogers, 1988; Savage and Lisowski, 1991) and a length of rupture between Alsea Bay and Neawanna of $175 \mathrm{~km}$ and between 
Alsea Bay and Netarts of $105 \mathrm{~km}$, the magnitude of a great megathrust paleoearthquake can be calculated. That they are great earthquakes is supported by estimates of subsidence $>0.5 \mathrm{~m}$, strong evidence for synchroneity over $100 \mathrm{~km}$ along the northern Oregon coast, evidence for tsunamis, and the off-shore turbidite data of Adams (1990). Using Wyss' equation ( $M_{\max }=\log A+$ 4.15) to determine magnitude where $A$ is equal to the rupture area, the size of paleoearthquake events $1 \mathrm{MT}, 3 \mathrm{MT}, 4 \mathrm{MT}$ and $5 \mathrm{MT}$ would be at least 8.3 and the size of 6MT at least 8.1. If extended into Washington (rupture length of $285 \mathrm{~km}$ ), the $1 \mathrm{MT}, 3 \mathrm{MT}$ and $4 \mathrm{MT}$ events would yield a magnitude of 8.6. Even if the rupture width is reduced to $50 \mathrm{~km}$, the magnitude of the earthquake would be at least 7.9.

Since the moment magnitude is more representative of the energy produced by an earthquake than the Wyss equation, the Kanamori equation $\left(M_{W}=2 / 3 \log M_{0}-10.7\right)$ is used to calculate the magnitude using an average recurrence interval of 450 years and a plate convergence rate of $4 \mathrm{~cm} / \mathrm{yr}$. $M_{0}$ is the product of the shear modulus, rupture area, and amount of seismic slip. The paleomagnitudes for coseismic events 1, 3, 4, and 5 between Alsea and Neawanna would be $8.5 \mathrm{M}_{\mathrm{w}}$ and the magnitude for event 6 between Alsea and Netarts would be $8.4 \mathrm{M}_{\mathrm{w}}$ (Figure 51). Extending events 1, 3 and 4 to Grays Harbor, Washington would yield a magnitude of $8.7 \mathrm{MW}_{\mathrm{w}}$. Using a range of convergence rates $(3.5-4.5 \mathrm{~cm} / \mathrm{yr})$ (Nishimura et al, 1984), recurrence intervals (300-500 years)(Peterson et al, 1991) and rupture widths $(50-90 \mathrm{~km})$, the range of magnitudes for paleoearthquakes between Alsea and Necanicum would be 8.2-8.6 $\mathrm{M}_{w}$, between Alsea and Netarts 8.1-8.5 $\mathrm{M}_{w}$, and between Alsea Bay and Grays Harbor 8.4-8.7 $\mathrm{M}_{\mathrm{w}}$. Based on the above calculations and the fact that a rupture length for historic great learthquakes of less than $105 \mathrm{~km}$ has never 


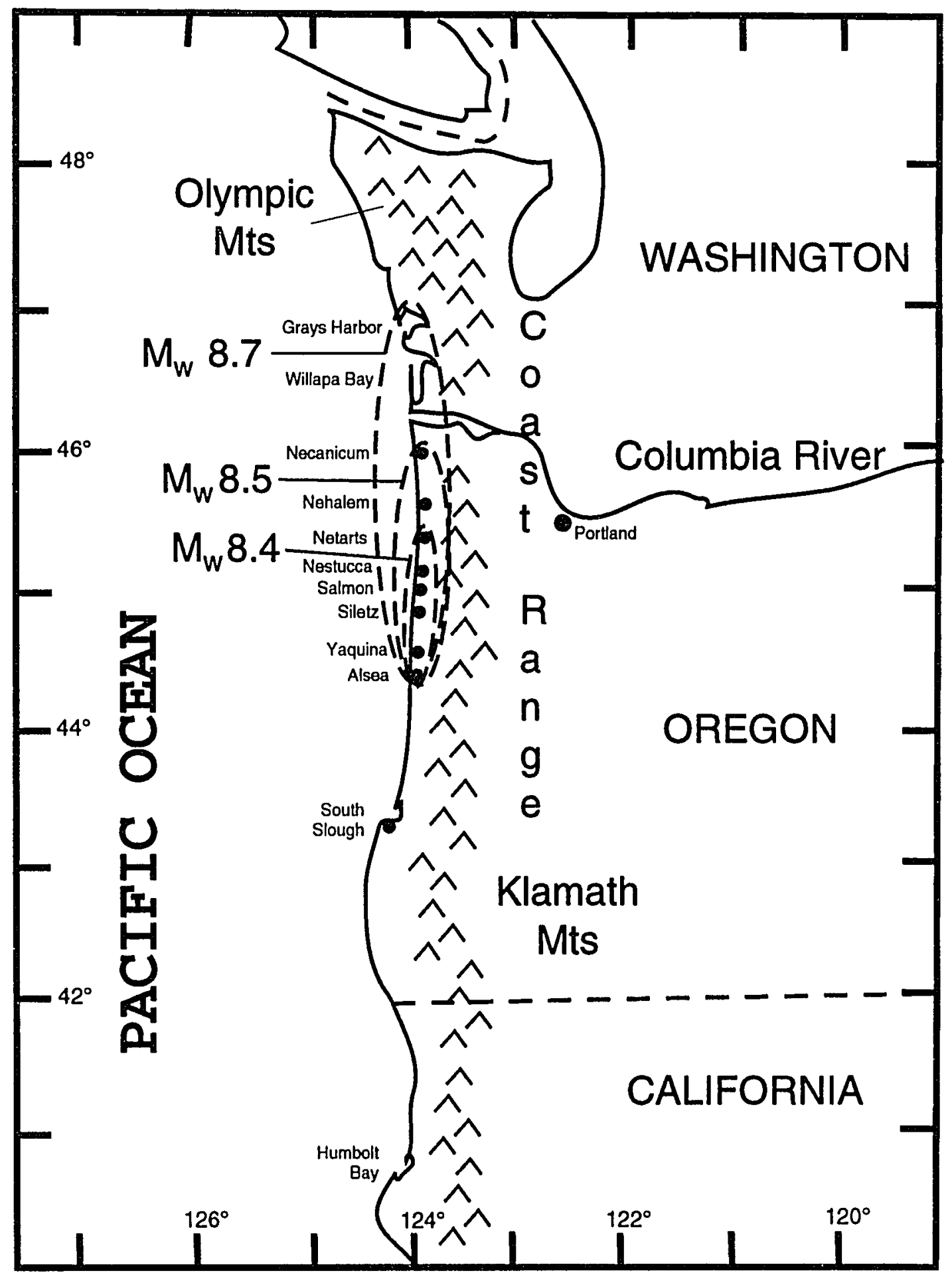

Eigure 51. The along-coast extent of three possible paleoearthquakes between Alsea Bay and Grays Harbor and their estimated magnitudes $\left(M_{W}\right)$. 
been recorded and historic great earthquakes of less than $8.0 \mathrm{M}_{\mathrm{w}}$ have been few (West and McCrumb, 1989), a magnitude of $8.1 \mathrm{M}_{\mathrm{w}}$ would be the minimum magnitude for paleoearthquakes along the northern Oregon coast. 


\section{CONCLUSIONS}

1) The mechanisms of burial for the top six burial events (1MT-6MT) in Alsea, Yaquina, Siletz, Nestucca, Netarts, and Necanicum are coseismic with two possible exceptions in Siletz Bay (1MT) and the Necanicum (4MT). The events are coseismic based on abrupt contacts between the buried peat (MT horizon) and overlying sediments (SCLS horizon), reduction in percent organics and increase in percent sand from the MT to the SCL/S horizon, changes in macroand microfossils from the MT to SCL/S horizon, increase in percent beach sand from the MT to SCL/S horizon, and widespread extent of the event. Evidence for tsunamis associated with these coseismic subsidence events have been recorded at Necanicum (1MT, 2MT, 3MT, and 5MT), Netarts Bay (1MT, 4MT, 5MT, and 6MT), Nestucca Bay (1MT), Siletz Bay (4MT and 5MT) and Alsea Bay (1MT, 2MT, and 4MT).

2) Synchroneity of events between Alsea Bay and the Necanicum River, covering a distance of $175 \mathrm{~km}$, is best documented for the $1 \mathrm{st}, 3 \mathrm{rd}, 4 \mathrm{th}$, and 5th events, whereas the sixth event is at least synchronous between Alsea Bay and Netarts Bay, a distance of $105 \mathrm{~km}$. The evidence used to support synchroneity is number of events in the top $3 \mathrm{~m}$, radiocarbon ages, degree of peat development, and the presence of distinct SCL's. The coseismic nature and the along-coast extent of the second event (2MT) is not clear. The 2MT event is best documented in Alsea Bay and the Necanicum (study end members) based on tsunami evidence, widespread correlation of the event within the estuary, and radiocarbon ages. 
3) The moment magnitudes of the paleoearthquakes recorded on the northern Oregon coast are at least $8.4 \mathrm{M}_{\mathrm{W}}$, based on a minimum rupture length of 105 $\mathrm{km}$, a rupture width of $90 \mathrm{~km}$, a recurrence interval of 450 years, and a convergence rate of $4 \mathrm{~cm} / \mathrm{yr}$. If the paleomagnitudes are calculated using different convergence rates $(3.5-4.5 \mathrm{~cm} / \mathrm{yr}$ ), recurrence intervals (300-500 years), and rupture widths $(50-90 \mathrm{~km})$, the magnitudes are no less than $8.1 \mathrm{M}_{\mathrm{w}}$. 


\section{RECOMMENDATIONS}

1) The evidence for paleoearthquakes of magnitudes greater than 8.0 is supported by this study as well as others. The next step is to more accurately determine recurrence intervals of the coseismic events, based on radiocarbon ages from the various bays, and from the ages statistically evaluate the probability of future events. This information can then be used by planners, politicians, educators and engineers to increase earthquake awareness, upgrade building codes, and retrofit critical structures like schools, hospitals, and bridges.

2) A more detailed paleoenvironmental reconstruction of the buried horizons is needed to improve estimates of subsidence as well as to strengthen support for coseismic subsidence. This can be accomplished by quantitative microfossil (diatom, foraminifera and possibly pollen) analyses of modern and prehistoric environments and a more rigorous search for macrofossils. A more quantitative study of sediment thicknesses of the $S$ and SCL horizons above the buried peat is required to support the fossil data, especially where there are variations in subsidence estimates for an individual burial event. For example, a change from a low marsh peat to a tidal flat mud would indicate less subsidence than a high marsh to tidal flat transition. If there is a thicker layer of sediment above a paleo-low marsh peat versus a paleo-high marsh peat within the same burial unit, the estimates of subsidence still could be the same. The lower marsh was dropped to a lower tidal flat elevation than the high marsh and therefore more 
sediment had to be deposited on the buried low marsh surface to return to a marsh setting.

More accurate subsidence estimates in the marsh stratigraphic record in the bays would improve Cascadia zone dislocation models that attempt to locate the zero isobase (boundary between coseismic uplift and subsidence) using the subsidence estimates of burial events along the Oregon coast, geodetic releveling surveys, and tide gauge data. Knowledge of changes in estimates of subsidence for the model are needed not only in a north-south direction but in an east-west direction as well. 


\section{REFERENCES}

Abe, K., 1977. Size of great earthquakes of 1837-1974 inferred from tsunami data. Journal of Geophysical Research, 84, 1561-1568.

Adams, J., 1984. Active deformation of the Pacific Northwest continental margin. Tectonics, 3, 449-472.

Adams, J., 1990. Paleoseismicity of the Cascadia subduction zone: Evidence from turbidites off the Oregon-Washington margin. Tectonics, 9, 569583.

Ando, M., 1975. Source mechanisms and tectonic significance of historical earthquakes along the Nankai trough, Japan. Tectonophysics, 27, 119-140.

Ando, M. and F.I. Balazs, 1979. Geodetic evidence for aseismic subduction of the Juan de Fuca plate. Journal of Geophysical Research, 84, 30233028.

Atwater, B.F., 1987. Evidence for great Holocene earthquakes along the outer coast of Washington state. Science, 236, 942-944.

Atwater, B.F. and C. Vita-Finzi, 1989. Net late Holocene emergence in the subsidence belt of the giant 1960 earthquake, southern Chile (abstract), EOS, 70, 1330-1331.

Atwater, B.F., S.P. Nishenko, A.G. Hull and J.B. Phipps, 1990. Buried Holocene lowlands and great-earthquake potential in coastal Washington (in preparation).

Baker, G.E. and C.A. Langston, 1987. Source parameters of the 1949 magnitude 7.1 south Puget Sound, Washington, earthquake as determined from long-period body waves and strong motions. Seismological Society of America Bulletin, 77, 1530-1537.

Baldwin, E.M., 1981. Geology of Oregen. Kendall/Hunt Publishing Company, Dubuque, lowa, 170p.

Bartsch-Winkler, S.R. and H.R. Schmoll, 1987. Earthquake-caused sedimentary couplets in the Upper Cook Inlet region, in T.D. Hamilton and J.P. Galloway (eds.), Geologic Studies in Alaska by the U.S. Geological Survey Circular 998, 92-95. 
Bourgeois, J. and M.A. Reinhart, 1989. Onshore erosion and deposition by the 1960 tsunami at the Rio Lingue estuary, south-central Chile (abstract), EOS, 70, 1331.

Byrne, D.E., D.M. Davies, and L.R. Sykes. Loci and maximum size of thrust earthquakes and the mechanics of the shallow region of subduction zones. Tectonics, 7, 833-857.

Clarke, S., 1991. Offshore neotectonics of the Cascadia subduction zone, Gorda segment (abstract). Oregon Department of Geology and Mineral Industries Workshop on Oregon Earthquake Source Zones, Corvallis, Oregon.

Connolly, T.J. and M.E. Darienzo, 1989. The geomorphic setting of archaeological sites on the southern Clatsop Plains, Oregon (abstract). 42nd Annual Northwest Anthropological Conference, Spokane, Washington.

Darienzo, M.E., 1987. Late Holocene geologic history of a Netarts Bay salt marsh, northwest Oregon coast and its relationship to relative sea level changes. M.S. thesis, University of Oregon, Eugene, 94p.

Darienzo, M.E. and C.D. Peterson, 1990. Episodic tectonic subsidence of Late Holocene salt marshes, northern Oregon, central Cascadia margin. Tectonics, 9, 1-22.

Fitch, T.J. and C.H. Scholz, 1971. Mechanism of underthrusting in southwest Japan: A model of convergent plate interactions. Journal of Geophysical Research, 76, 7260-7292.

Franklin, A.G., L.F. Orozco, and R. Semrau, 1973. Compaction and strength of slightly organic soils. Journal of the Soil Mechanics and Foundations Division, 99, 541-557.

Folk, R.L., 1980. Petrology of Sedimentary Rocks. Hemphill Publishing Company, Austin, Texas, 185p.

Goodwin, C.R., E.W. Emmett, and B. Glenne, 1970. Tidal study of three Oregon estuaries. Engineering Experiment Station Bulletin No. 45, Oregon State University, Corvallis, Oregon, 32p.

Grant, W.C., 1989. More evidence from tidal-marsh stratigraphy for multiple late Holocene subduction earthquakes along the northern Oregon coast (abstract), Geological Society of America Abstracts with Programs, 21, 86. 
Grant, W.C., B.F. Atwater, G.A. Carver, M.E. Darienzo, A.R. Nelson, C.D. Peterson, and G.S. Vick, 1989. Radiocarbon dating of late Holocene coastal subsidence above the Cascadia Subduction ZoneCompilation for Washington, Oregon, and northern California (abstract). EOS, 70, 1331.

Grant, W.C. and D.D. McLaren, 1987. Evidence for Holocene subduction earthquakes along the northern Oregon coast (abstract). EOS, 68, 1469.

Heaton, T.H. and S.H. Hartzell, 1987. Earthquakes hazards on the Cascadia Subduction Zone. Science, 236, 162-168.

Heaton, T.H. and H. Kanamori, 1984. Seismic potential associated with subduction in the northwestern United States. Bulletin of the Seismological Society of America, 74, 933-941.

Heaton, T.H. and P.D. Snavely, 1985. Possible tsunami along the northwestern coast of the United States inferred from Indian traditions. Bulletin of the Seismological Society of America, 75, 1455-1460.

Jefferson, C.A., 1975. Plant communities and succession in Oregon coastal salt marshes. PhD thesis, Oregon State University, Corvallis, 192p.

Kanamori, H., 1977. The energy release in great earthquakes. Journal of Geophysical Research, 82, 2981-2987.

Kanamori, H., 1983. Magnitude scale and quantification of earthquakes. Tectonophysics, 93, 185-199.

Kanamori, H. and K.C. McNally, 1982. Variable rupture mode of the subduction zone along the Ecuador-Columbia coast. Bulletin of the Seismological Society of America, 72, 1241-1253.

Kroeber, A.L., 1976. How the prairie became ocean, in Yurok Myths, University of California Press, Berkeley, California, 488p.

Kulm, L.D. and J.V. Byrne, 1967. Sediments of Yaquina Bay, Oregon, in Estuaries, American Association for the Advancement of Science, 226238.

Langston, C.A. and D.E. Blum, 1977. The April 29, 1965, Puget Sound earthquake and the crustal and upper mantle structure of western Washington. Seismological Society of America Bulletin, 67, 693-711.

Michaelson, C.A. and C.S. Weaver, 1986. Upper Mantle structure from teleseismic $P$ wave arrivals in Washington and northern Oregon. Journal of Geophysical Research, 91, 2077-2094. 
Minor, R, 1984. Dating of Bonneville landslide in the Columbia River Gorge, Heritage Research Associates Report No. 31, Portland District U.S. Army Corps of Engineers, Contract No. DACW57-83-C-0033, 19p.

Minoura, K. and S. Nakaya, 1991. Traces of tsunami preserved in inter-tidal lacustrine and marsh deposits: Some examples from northeast Japan. Journal of Geology, 99, 265-287.

Nelson, A.R., 1987. Apparent gradual rise in relative sea level on the southcentral Oregon coast during the late Holocene--Implications for the great Cascadia earthquake hypothesis (abstract), EOS, 68, 1240.

Nishimura, C., D.S. Wilson, and R.N. Hey, 1984. Pole of rotation analysis of present-day Juan de Fuca plate motion. Joumal of Geophysical Research, 89, 10, 283-10,290.

Oregon Department of Land Conservation and Development, 1987. The Qregen Estuary Plan Book, Salem, Oregon, 126p.

Patrick, R. and C.W. Reimer, 1986. The Diatoms of the United States, Volume1. Academy of National Sciences, Philadelphia, PA, 688p.

Percy, K.L., C. Sutterlin, D.A. Bella, and P.C. Klingeman, 1974. Descriptions and information sources for Oregon estuaries. Oregon State University Sea Grant College Program, Corvallis, Oregon, 294p.

Peterson, C., K. Scheidegger, and P. Komar, 1982. Sand-dispersal patterns in an active-margin estuary of the northwestern United States as indicated by sand composition, texture and bedforms. Marine Geology, 50, 77-96.

Peterson, C.D., K.F. Scheidegger, and H.J. Schrader, 1984. Holocene depositional evolution of a small active-margin estuary of the northwestern United States. Marine Geology, 59, 51-83.

Peterson, C.D. and M.E. Darienzo, 1991. Discrimination of climatic, oceanic and tectonic mechanisms of cyclic marsh burial from Alsea Bay, Oregon, U.S.A. (USGS Professional Paper, in press).

Peterson, C.D., M.E. Darienzo, and C. Clough, 1991. Recurrence intervals of coseismic subsidence events in northern Oregon bays of the Cascadia margin. Final Technical Progress Report to the Department of Geology and Mineral Resources, $14 \mathrm{p}$. 
Peterson, C.D., M.E. Darienzo, and A.G. Johnson, 1991. New estimates of megathrust earthquake magnitude and recurrence interval in the central Cascadia margin (abstract). Oregon Department of Geology and Mineral Industries Workshop on Oregon Earthquake Source Zones, Corvallis, Oregon.

Peterson, C.D., K. Scheidegger, P. Komar, and W. Niem, 1984. Sediment composition and hydrography in six high-gradient estuaries of the northwestern United States. Journal of Sedimentary Petrology, 54, 8697.

Peterson, C.P., L.D. Kulm, and J.J. Gray, 1986. Geologic map of the ocean floor off Oregon and the adjacent continental margin. State of Oregon Department of Geology and Mineral Industries Geological Map Series, GMS-42.

Plafker, G., 1972. Alaskan earthquake of 1964 and Chilean earthquake of 1960: Implications for arc tectonics. Journal of Geophysical Research, $77,901-925$.

Plafker, G., 1991. Regional vertical tectonic displacement of shorelines in south-central Alaska during and between great earthquakes. Northwest Science, 64, 250-258.

Plafker, G. and R. Kachadoorian, 1966. Geologic effects of the March 1964 earthquake and associated seismic sea waves on Kodiak and nearby islands, Alaska. U.S. Geological Survey Professional Paper 543-D, $46 \mathrm{p}$.

Rankin, D.K., 1983. Holocene geologic history of the Clatsop Plains foredune ridge complex. M.S. Thesis, Portland State University, Portland, Oregon, 176p.

Reilinger, R. and J. Adams, 1982. Geodetic evidence for active landward tilting of the Oregon and Washington coastal ranges. Geophysical Research Letters, 9, 401-403.

Reinhart, M.A. and J. Bourgeois, 1987. Distribution of anomalous sand at Willapa Bay, Washington: Evidence for large scale landward-directed processes (abstract). EOS, 68, 1469.

Reinhart, M.A. and J. Bourgeois, 1989. Tsunami favored over storm or seiche for sand deposit overlying buried Holocene peat (abstract), EOS, 70 , 1331.

Rejmanek, M., C.E. Sasser, and G.W. Peterson, 1988. Hurricane-induced sediment deposition in a gulf coast marsh. Estuarine, Coastal and Shelf Science, 27, 217-2.22. 
Riddihough, R., 1984. Recent movements of the Juan de Fuca plate system. Journal of Geophysical Research, 89, 6980-6994.

Rogers, G.C., 1988. An assessment of the megathrust potential of the Cascadia subduction zone. Canadian Journal of Earth Sciences, 25, 844-852.

Savage, J.C., 1983. A dislocation model of strain accumulation and release at a subduction zone. Journal of Geophysical Research, 88, 4984-4996.

Savage, J.C. and M. Lisowski, 1991. Strain measurements and the potential for a great subduction earthquake off the coast of Washington. Science, $252,101-103$.

Seed, H.B., K. Tokimatsu, and L. Harder, 1984. The influence of SPT procedures in evaluating soil liquefaction resistance. Report No. UCB/EERC-84-15, Earthquake Engineering Research Center, U. of California, Berkeley, California.

Smith, D.G., 1987. A mini-vibracoring system. Journal of Sedimentary Geology, 57, 757-758.

Spence, W., 1989. Stress origins and earthquake potentials in Cascadia. Journal of Geophysical Research, 94, 3076-3088.

Stuiver, M. and P.J. Reimer, 1986. A computer program for radiocarbon age calibration. Radiocarbon, 28, 1022-1030.

Stumpt, R.P., 1983. The process of sedimentation on the surface of a salt marsh. Estuarine, Coastal and Shelf Science, 17, 495-508.

Thatcher, W. and J.B. Rundle, 1984. A viscoelastic coupling model for the cyclic deformation due to periodically repeated earthquakes at subduction zones. Journal of Geophysical Research, 89, 7631-7640.

Tokimatsu, K. and H.B. Seed, 1987. Evaluation of settlement in sands due to earthquake shaking. Journal of Geotechnical Engineering, 113, 861878.

Uniform Building Code, 1988. International Conference of Building Officials, Whittier, California, 926p.

Vick, G.S., 1988. Late Holocene paleoseismicity and relative sea level changes of the Mad River Slough, northern Humboldt Bay, California. M.S. thesis, Humboldt State University, Arcata, California, 87p.

Vincent, P., M.A. Richards, and R.J. Weldon II, 1991. Vertical interseismic deformation of the Oregon Cascadia margin. Journal of Geophysical Research, submitted. 
Weaver, C.S. and G.E. Baker, 1988. Geometry of the Juan de Fuca plate beneath Washington and northern Oregon from seismicity. Bulletin of the Seismological Society of America, 78, 264-275.

West, D.O. and D.R. McCrumb, 1988. Coastline uplift in Oregon and Washington and the nature of Cascadia subduction-zone tectonics. Geology, 15, 169-172.

Whiting, C.S. and C.D. McIntire, 1985. An investigation of distributional patterns in the diatom flora of Netarts Bay, Oregon, by correspondence analysis. Journal of Phycology, 21, 655-661.

Woodward, J., J. White, and R. Cummings, 1990. Paleoseismicity and the archaeological record: Areas of investigation on the northern Oregon coast. Oregon Geology, 52, 57-65.

Wyss, M., 1979. Estimating maximum expectable magnitude of earthquakes from fault dimensions. Geology, 7, 336-340.

Yamaguchi, D.K., C.A. Wodehouse and M.S. Reid, 1989. Tree-ring evidence for synchronous rapid submergence of the southwestern Washington coast 300 years B.P. (abstract), EOS, 70, 1332. 
APPENDIX A

LABORATORY PROCEDURES 


\section{Loss on Ignition (LOI)}

1) Sample was collected, placed in numbered crucible, and dried for $24 \mathrm{hrs}$ at $100^{\circ} \mathrm{C}$.

2) The sample was placed in a desiccator to cool and then weighed.

3) The sample was then placed in a furnace and combusted at $450^{\circ} \mathrm{C}$ for $5 \mathrm{hrs}$ (extra samples from Netarts Bay were combusted at $380 \mathrm{C}$ for at least 10 hours).

4) The sample was placed in a desiccator to cool and then weighed.

5) The weights of the dry sample pre-combustion and post-combustion were determined.

6) The percent LOI was calculated using the following formula.

$$
\begin{array}{cl}
\% L O I=\underline{W}_{2}-W_{1} \times 100 & W_{0} \text { dry weight pre combustion } \\
W_{0} & W_{1} \text { dry weight post combustion }
\end{array}
$$

\section{Grain Size Analysis}

1) Sample was collected, placed in at least a $600 \mathrm{ml}$ size beaker, mixed with a little water, and mashed with a rubber policeman to break up clumps.

2) The beaker was placed on a warm hot plate in a fume hood and $30 \%$ hydrogen peroxide was added to the sample to remove fine organics.

3) After 24 hours, the sample was wet sieved through either a $1 \mathrm{~mm}$ or $0.5 \mathrm{~mm}$ sieve, dependent on the estimated sand size of sample, to remove coarse organics and a $62 \mu$ sieve (sand/silt break) sieve. The sand collected on the $62 \mu$ sieve was placed in a $50 \mathrm{ml}$ beaker (any organics remaining were decanted), dried at $60^{\circ} \mathrm{C}$, and then weighed the next day. The silt/clay fraction was collected in a container during the sieving process and transferred to a beaker, dried at $60^{\circ} \mathrm{C}$, and also weighed the next day. 
4) The percent sand and silt/clay were then calculated.

\section{Qualitative Diatom Analysis}

1) Diatom samples were collected from the sitt/clay mixture (step 7 for grain size analysis) and transferred to labeled plastic vials before the mixture was placed in the oven. Time (5-10 minutes) was allowed for the diatoms to settle to the bottom of the container prior to collection with an eye dropper. This was done to improve diatom recovery.

2) A sample (one drop) was transferred to a labeled slide and diluted with 1-3 drops of water, if sample was too concentrated, and dried on a hot plate.

3) A slide was mounted using Preservaslide, a permanent mounting medium, and a cover slip.

\section{Heavy Mineral Analysis}

1) Sample was wet sieved through 62 and $250 \mu$ sieves and the heavy mineral analysis fraction, collected on the $62 \mu$ sieve, was then dried.

2) The sample was placed in a test tube filled with sodium polytungstate (2.95 $\mathrm{g} / \mathrm{ml}$ ) and centrifuged at 30 RPM for 10-15 minutes to separate the heavy minerals from the light minerals. If the sample was larger than the optimum size then it was split prior to placement in the polytungstate.

3) The bottom of the tube was placed in liquid nitrogen to freeze the heavy minerals now at the bottom of the tube.

4) First the light minerals at the top of the tube were poured off into a filter and, then when the bottom thawed, the heavy minerals were poured into a filter.

5) The samples in the filters were rinsed and then placed in an oven to dry.

6) The heavy mineral fraction was transferred to a slide and covered with mounting medium (Piccolyte) and cover slip. 
7) 100 grains were counted to determine the percentage of beach and river sand and 10 grains were counted for an estimate of grain size. A semiquantitative count based on roundness (beach grains more rounded than river grains) and mineralogy [heavy minerals with a beach (e.g. hypersthene and epidote) or upland (e.g. augite) source] was used (Peterson et al, 1982).

\section{Radiocarbon sample preparation}

\section{Bulkpeat}

1) The sample was wet sieved with tap water through both $850 \mu$ and $62 \mu$ sieves to collect coarse and fine organics, respectively.

2) The samples were placed in labeled (sample collection site, core depth or cutbank location) crucibles and dried at $60^{\circ} \mathrm{C}$ overnight.

3) Each sample was weighed and wrapped in labeled aluminum foil.

4) The samples (either coarse fraction or both) were sent to a radiocarbon dating laboratory for age determinations.

\section{Wood or charcoal}

1) The sample was rinse with tap water to remove inorganics, then dried at $60^{\circ} \mathrm{C}$ overnight.

2) The contaminated (algae etc.) outer part of the wood was removed with either sand paper or band saw. Then see 3-4 above. 


\section{APPENDIX B}

\section{SEDIMENT CLASSIFICATION}


Inorganic sediments

Sand

Muddy sand

Sandy mud

Mud

\author{
$>90 \%$ sand \\ $\geq 50 \%$ sand and $<50 \%$ silt/clay \\ $>50 \%$ silt/clay and $<50 \%$ sand \\ $>90 \%$ silt/clay
}

Organic sediments (percent loss on ignition)

(blanks to be filled in with sand(y), mud(dy) or combination)

Alsea and Netarts Bay

Peat

Peaty

Slightly' peaty

Rooted

Slightly rooted

Barren

All other bays

Peat

peat

Peaty

Slightly' peaty

Rooted

Slightly rooted

Barren $\geq 50 \%$

$\geq 25 \%$ and $<50 \%$

$\geq 15 \%$ and $<25 \%$

$\geq 10 \%$ and $<15 \%$

$\geq 8 \%$ and $<10 \%$

$\geq 5 \%$ and $<8 \%$

$<5 \%$

$256 \%$

$228 \%$ and $<56 \%$

$\geq 17 \%$ and $<28 \%$

$211 \%$ and $<17 \%$

$29 \%$ and $<11 \%$

$26 \%$ and $<9 \%$

$<6 \%$ 
APPENDIX C

PERCENT LOSS ON IGNITION COMPARISONS 
Wee Willies

Little Nestucca 5

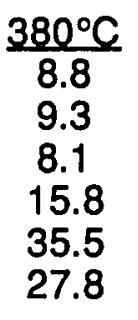

33.5

18.9

26.5

14.3

40.4

14.1

26.1

14.4

26.6 $450^{\circ} \mathrm{C}$

9.5

10.8

9.3

20.0

43.1

28.3

36.1

19.3

33.9

19.5

40.6

15.2

32.2

14.8

27.4
$\%$ increase

14

13

21

18

2

7

2

22

27

$<1$

7

19

3 


\section{APPENDIX D}

TIDAL ELEVATION DATA 
The elevations of core sites, cutbanks, and other locations in the bay are summarized in this appendix. The tidal data that was used as the basis of elevation estimates are also included. The sites are related to Mean Tide Level (MTL) and when possible to Mean Sea Level (National Geodetic Vertical Datum). Non-statistical errors for the mean tide levels and mean sea levels are $\pm 0.3 \mathrm{~m}$ for Neawanna, $\pm 0.15 \mathrm{~m}$ for Nestucca, \pm 0.08 for Siletz, and $\pm 0.03 \mathrm{~m}$ (Oysterville and Hattield sites) or $\pm 0.15 \mathrm{~m}$ (Slack and Conser sites) for Yaquina. The non-statistical error is based on the judgement of Henry Pittock, tides specialist from the College of Oceanography at Oregon State University. Two sets of tidal data were used for Yaquina as the bases for estimating mean tidal elevations. The set in the left column are based on tide gauges established near the mouth of the Yaquina at South Beach. Oysterville and Hatfield elevations were calculated from this data. The set in the right column are based on gauges established in the Toledo area. The Slack and Conser core site elevations were calculated from the Toledo data. 
Neawanna

Core Sites

$M T L(m) \quad M S L(m)$

1

1.63

1.04

2

1.49

0.9

3

1.82

1.23

4

5

2.21

1.69

1.62

6

7

1.39

1.1

1.3

0.8

8

1.27

0.71

0.68

\section{Cutbanks}

1
4
5
6
7
8

0.78

0.19

1.82

1.23

1.61

1.02

1.74

1.15

1.77

1.18

1.38

0.79

Forest/high marsh transition 1.48

0.89

High marsh

0.71

0.12

High marsh/low marsh transition 0.52

$-0.07$

Buried tree root

0.1

$-0.49$

Low marsh/tidal flat transition -0.01

$-0.6$

Tidal flat

$-0.6$

$-1.19$

Mean High High Water (MHHW)

Mean High Water (MHW)

1.77

0.94

Mean Tidal Level (MTL)

1.55

0.72

Mean Sea Level (MSL) or National

0.83

0

Geodetic Vertical Datum (NGVD)

Mean Low Water (MLW)

$0.24 \quad-0.59$

Mean Low Low Water (MLLW)

0.12

$-0.71$

0

$-0.83$ 


\section{NESTUCCA}

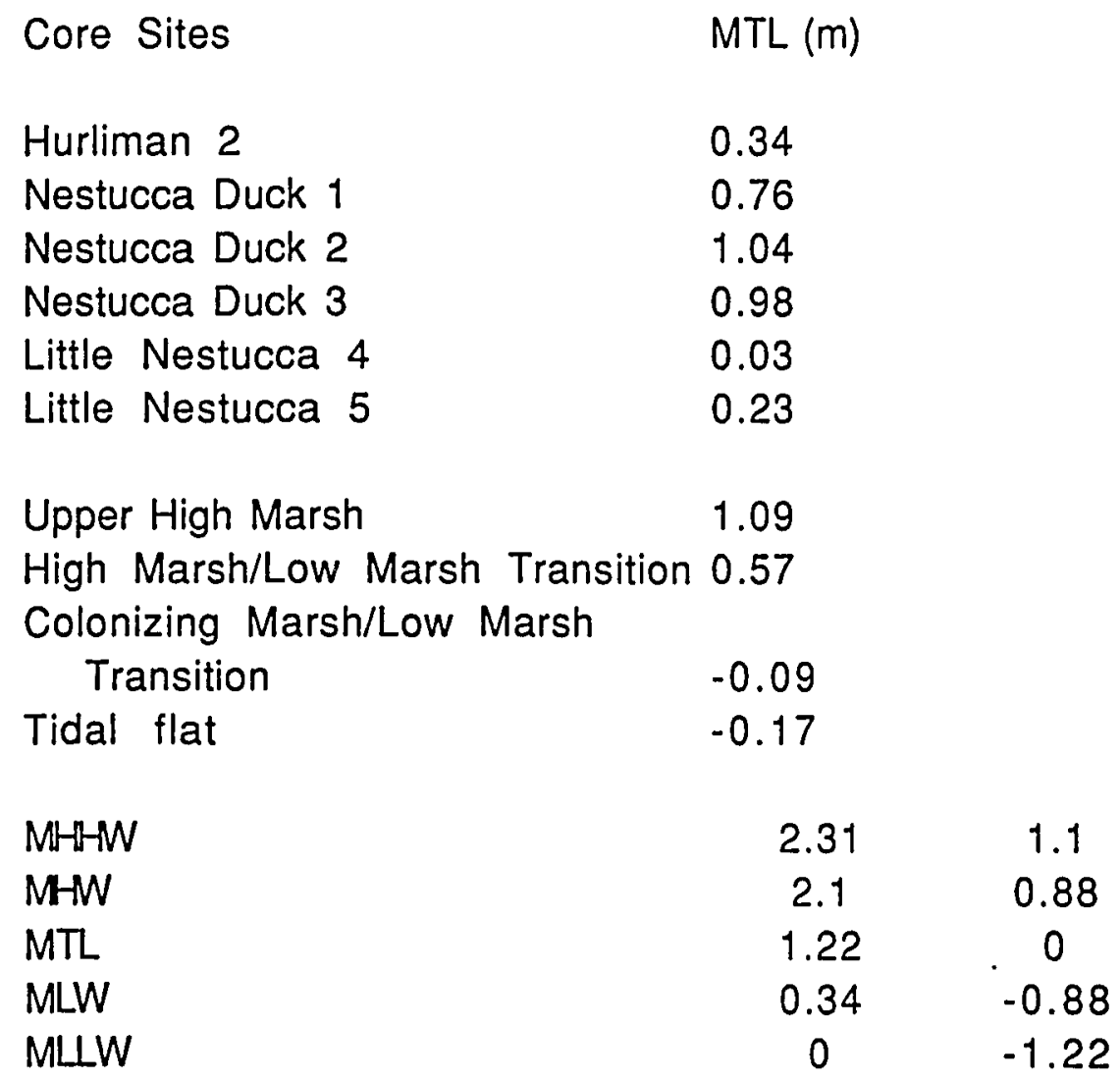


SILETZ

Core Sites

$\operatorname{MTL}(m) \quad M S L(m)$

Salishan House

1.18

0.84

Salishan Spit

1.28

0.94

Siletz Spit

1.09

0.75

Millport 1

1.34

1

Siletz River

1.15

0.81

Alder

0.8

0.46

Cutbanks

$\begin{array}{lcc}\text { Millport 1 } & 1.58 & 1.24 \\ \text { Millport 3 } & 1.37 & 1.03 \\ \text { Millport } 4 & 1.43 & 1.09 \\ \text { Millport 5 } & 1.49 & 1.15 \\ & & \\ \text { High Marsh } & 1.04 & 0.7 \\ \text { High Marsh } & 1.09 & 0.75 \\ \text { Intermediate Marsh } & 0.81 & 0.47 \\ \text { Low Marsh } & 0.77 & 0.43 \\ \text { Colonizing Marsh/Tidal Flat } & & \\ \text { Transition } & 0.24 & -0.1 \\ & & \\ \text { M-HW } & 1.85 & 0.91 \\ \text { MHW } & 1.64 & 0.7 \\ \text { MTL } & 0.94 & 0 \\ \text { MSL (NGVD) } & 0.6 & -0.34 \\ \text { MLW } & 0.24 & -0.7 \\ \text { MLLW } & 0 & -0.94\end{array}$


YAQUINA

Core Sites

$\operatorname{MTL}(m) \quad M S L(m)$

Hatfield 1

$1.74 \quad 1.62$

Hatfield 2

$1.43 \quad 1.31$

Hatfield 3

$1.51 \quad 1.39$

Oysterville 4

$1.37 \quad 1.25$

Oysterville 5

$1.38 \quad 1.26$

Slack 1

$0.43 \quad 0.25$

Slack 2

0.37

0.19

Slack 3

0.31

0.13

Slack 5

0.41

0.23

Conser 1

1.06

0.88

Conser 2

0.82

0.64

Cutbanks

\begin{tabular}{l|lll} 
Oysterville 1 & & 1.16 & 1.04 \\
Oysterville 2 & & 1.16 & 1.04 \\
Oysterville 3 & & 1.28 & 1.16 \\
Slack CB & & 1.41 & 1.23 \\
& & & \\
High Marsh & & 1.35 & 1.23 \\
High/Low Marsh & Transition & 1.31 & 1.19 \\
Low Marsh & 1.23 & 1.11 \\
Low Marsh & & 1.17 & 1.05 \\
Low Marsh/Tidal & Flat Transition & 0.97 & 0.85 \\
Tidal Flat & & 0.61 & 0.49
\end{tabular}




$\begin{array}{lcccc}\text { MHHW } & 2.53 & 1.16 & 2.47 & 1.19 \\ \text { MHW } & 2.31 & 0.94 & 2.22 & 0.94 \\ \text { MTL } & 1.37 & 0 & 1.28 & 0 \\ \text { MSL (NGVD) } & 1.25 & -0.12 & 1.1 & -0.18 \\ \text { MLW } & 0.39 & -0.98 & 0.3 & -0.98 \\ \text { MLWW } & 0 & -1.37 & 0 & -1.28\end{array}$




\section{APPENDIX E}

SUMMARY OF HYDROGRAPHY AND PHYSIOGRAPHY DATA FROM ALL BAYS 
BAY

Necanicum River

Necanicum River

Neawanna River

Netarts Bay

Nestucca Bay

Nestucca River

Little Nestucca River

Siletz Bay

Yaquina Bay

Alsea Bay
Distance from

Columbia River River length Head of Tide

$(\mathrm{km})$

$(\mathrm{km})$

$(\mathrm{km})$

26

34

11

4

6

96

121

$85 \quad 11$

$31 \quad 4$

$153 \quad 116 \quad 39$

185

208

95

42

78

26

\section{Drainage Area FW yield Sediment yield \\ (sq. $\mathrm{km}$ ) (cubic meters (tonnes) \\ $x$ million)}

Necanicum River

225

270

Necanicum River

Neawanna River

Netarts Bay

Nestucca Bay

Nestucca River

Little Nestucca River

Siletz Bay

Yaquina Bay

Alsea Bay

36

834

667

167

966

655

1228
52

1970

2014

49000

2200

67100

966

27200

1850

225843 
BAY

Necanicum River

Necanicum River

Neawanna River

Netarts Bay

Nestucca Bay

Nestucca River

Little Nestucca River

Siletz Bay

Yaquina Bay

Alsea Bay
Tidal range

1.76

Estuary area (hectares)

Nestucca Bay

Nestucca River

Little Nestucca River

Siletz Bay

Yaquina Bay

Alsea Bay (m)

1.7

1.5

1.8

1.77

112

931

429

Tidal prism (cubic meters

$x$ million)

17

9

9.9

24

14

Wetlands

(percent)

29.4

8.3

17.4

469

18.8

14.2

18.3 


\section{APPENDIX F}

RESULTS OF LABORATORY ANALYSES 
All results of the laboratory analyses are found in this appendix. The data are arranged according to the bays starting with the Necanicum and ending with the Yaquina. The column descriptions are as follows: 1) Horizon (Hor) is the burial unit designation, 2) depth is depth below the surface, 3) \% LOI or LOI is the percent organic content in that horizon, 4) \% sand or sand is the percentage of sand in that horizon, 5) \% beach or beach is the percentage of heavy minerals with a beach source, and 6) diatom (Dia) indicates the overall character of the assemblage [brackish/marine (B or $b$ ) vs. freshwater $(F$ or $f)$ ]. Where there are two diatom designations (e.g. $\mathrm{Fb}$ ) in which one is lowercase, the lower case indicates a minor influence of that assemblage. When both are uppercase (FB or $\mathrm{BF}$ ), no strong dominance was recognized and both assemblages are either evenly represented or one is slightly dominant. The core site abbreviations are Nea (Neawanna), N (Netarts), WW (Wee Willies), OyF (Oyster Farm), LNes (Little Nestucca), Nes (Nestucca), NDuck (Nestucca Duck), Hur (Hurliman), Sal H (Salishan House), Mill (Millport), SilR (Siletz River), Slk (Slack), Oyst (Oysterville), and Hat (Hatfield). 


\begin{tabular}{|c|c|c|c|c|c|}
\hline Horizon Nea 2 & Depth Nea 2 & $\%$ LOI Nea 2 & \%Sand Nea 2 & \%Beach Nea 2 & Dia Nea 2 \\
\hline OMT & 5 & 50.3 & 3 & & $F$ \\
\hline os & 40 & 20.1 & 8 & & $\mathrm{~F}$ \\
\hline $1 \mathrm{MT}$ & 48 & 37.5 & 4 & & $\mathrm{~F}$ \\
\hline 15 & 68 & 38.5 & 4 & 12 & $\mathrm{~F}$ \\
\hline $2 M T$ & 70 & 48.4 & 3 & 0 & $\mathrm{~F}$ \\
\hline $2 S$ & 95 & 18.2 & 7 & & $\mathbf{F}$ \\
\hline $2 S C L$ & 98 & 3 & 89 & 22 & \\
\hline $3 M T$ & 111 & 20.9 & 33 & 18 & $F$ \\
\hline 35 & 140 & 20.1 & 9 & & $\mathrm{~F}$ \\
\hline $3 S C L$ & 150 & 18.8 & 32 & 0 & $F$ \\
\hline $4 \mathrm{MT}$ & 158 & 22.1 & 7 & 0 & $\mathrm{Fb}$ \\
\hline $4 S$ & 186 & 19.8 & 14 & 17 & FB \\
\hline $5 \mathrm{MT}$ & 190 & 27.1 & 6 & 6 & BF \\
\hline $5 S$ & 252 & 12 & 16 & 11 & FB \\
\hline $5 S C L$ & 258 & 8.1 & 39 & 34 & $\mathrm{Fb}$ \\
\hline $6 M T$ & 268 & 31.8 & 1 & 9 & FB \\
\hline Horizon Nea 5 & Depth Nea 5 & $\%$ LOINea 5 & $\%$ Sand Nea 5 & \%Beach Nea 5 & Dia Nea 5 \\
\hline OMT & 5 & 10.8 & 48 & & FB \\
\hline os & 25 & 13.9 & 55 & & $\mathrm{~F}$ \\
\hline OSCL & 33 & 9.5 & 61 & 7 & FB \\
\hline $1 \mathrm{MT}$ & 40 & 11.4 & 49 & 11 & $\mathbf{F}$ \\
\hline 1S & 68 & 12 & 41 & 7 & $\mathrm{Fb}$ \\
\hline $1 S C L$ & 70 & 11.6 & 58 & 19 & FB \\
\hline $2 \mathrm{MT}$ & 78 & 9.9 & 49 & 7 & FB \\
\hline $2 S$ & 98 & 15.6 & 30 & 12 & FB \\
\hline 3MT & 102 & 26.1 & 4 & 8 & $\mathrm{~F}$ \\
\hline $3 S$ & 120 & 21.5 & 11 & 0 & $\mathbf{F}$ \\
\hline $4 M T$ & 125 & 25.2 & 6 & 0 & $\mathbf{F}$ \\
\hline $4 S$ & 147 & 14.4 & 16 & 7 & $\mathbf{F}$ \\
\hline $4 S C L$ & 151 & 14 & 54 & 15 & \\
\hline $5 \mathrm{MT}$ & 154 & 16.1 & 25 & 8 & $\mathrm{~F}$ \\
\hline $5 S$ & 163 & 9.6 & 30 & 6 & Fo \\
\hline $6 M T$ & 167 & 37.3 & 1 & 7 & FB \\
\hline $6 S$ & 194 & 16.3 & 28 & & $\mathrm{Fb}$ \\
\hline
\end{tabular}




\begin{tabular}{|c|c|c|c|c|c|}
\hline Horizon Nea 7 & Depth Nea 7 & $\%$ LOI Nea 7 & \%Sand Nea 7 & \%Beach Nea 7 & Dia Nea 7 \\
\hline OMT & 5 & 15 & 13 & & BF \\
\hline os & 40 & 14.3 & 18 & 9 & $B F$ \\
\hline$O S C L$ & 48 & 14.2 & 49 & 17 & $B F$ \\
\hline $1 \mathrm{MT}$ & 52 & 14.5 & 37 & 6 & $B F$ \\
\hline 15 & 76 & 13.6 & 63 & 10 & $B F$ \\
\hline 2MT & 87 & 20.3 & 28 & 4 & FB \\
\hline $2 S$ & 103 & 8.3 & 66 & 22 & $\mathrm{Fb}$ \\
\hline 3MT & 111 & 25 & 12 & 8 & $\mathrm{~F}$ \\
\hline 35 & 130 & 17.8 & 55 & 4 & $\mathrm{~F}$ \\
\hline 4MT & 138 & 41.6 & 14 & & $F$ \\
\hline $4 S$ & 178 & 16.8 & 13 & & $\mathrm{Fb}$ \\
\hline Hor Nea 1 & Depth Nea 1 & LOI Nea 1 & & & \\
\hline OS & 50 & 49 & & & \\
\hline $1 \mathrm{MT}$ & 57 & 53.8 & & & \\
\hline 15 & 87 & 20.4 & & & \\
\hline 2MT & 92 & 46.9 & & & \\
\hline $4 S$ & 195 & 25.2 & & & \\
\hline $5 \mathrm{MT}$ & 205 & 32.8 & & & \\
\hline $5 S$ & 250 & 12.4 & & & \\
\hline Hor Nea CB3 & Depth Nea CB3 & & Sand Nea CB3 & & \\
\hline 1SCL & 122 & & 73 & & \\
\hline Hor Nea CB4 & Depth Nea CB4 & & Sand Nea CB4 & & \\
\hline OSCL & 98 & & 73 & & \\
\hline $1 \mathrm{SCL}$ & 131 & & 77 & - & \\
\hline Hor Nea 6 & Depth Nea 6 & LOI Nea 6 & & & \\
\hline $4 \mathrm{MT}$ & 150 & 18.6 & & & \\
\hline $4 S$ & 195 & 19.1 & & & \\
\hline 5MT & 205 & 28 & & & \\
\hline $5 S$ & 250 & 5 & & & \\
\hline Hor Nea 8 & Depth Nea 8 & & Sand Nea 8 & Beach Nea 8 & \\
\hline OSCL & 15 & & 91 & 9 & \\
\hline $1 \mathrm{MT}$ & 25 & & 43 & 8 & \\
\hline
\end{tabular}




\begin{tabular}{|c|c|c|c|c|c|}
\hline $\begin{array}{l}\text { Hor N7 } \\
\text { OS }\end{array}$ & $\begin{array}{c}\text { Depth N7 } \\
69\end{array}$ & LOIN7 & Sand N7 & $\begin{array}{c}\text { Beach N7 } \\
100\end{array}$ & Dia N7 \\
\hline $\mathrm{OSCL}$ & 83 & & 74 & 100 & \\
\hline $1 \mathrm{MT}$ & 89 & & & & \\
\hline $3 S$ & 115 & & & 100 & \\
\hline $3 S C L$ & 142 & & 69 & 100 & \\
\hline $4 S$ & 200 & & & 100 & \\
\hline $4 S C L$ & 245 & & 83 & 100 & \\
\hline $5 M T$ & 255 & 3.8 & & 100 & \\
\hline $5 \mathrm{SCL}$ & 270 & & 87 & 100 & B \\
\hline $6 M T$ & 286 & 8.6 & & & B \\
\hline $6 \mathrm{~S}$ & 350 & & & & B \\
\hline $7 S$ & 385 & & & & B \\
\hline $8 \mathrm{MT}$ & 391 & 24.1 & & & $F / b$ \\
\hline $8 S C L$ & 440 & & 91 & 100 & B \\
\hline Hor $\mathrm{N}_{12}$ & Depth N12 & & & & Dia N12 \\
\hline $7 \mathrm{MT}$ & 377 & & & & B \\
\hline 75 & 387 & & & & B \\
\hline Hor N5 & Depth N5 & & & & Dia N5 \\
\hline 53 & 313 & & & & B \\
\hline $6 \mathrm{MT}$ & 316 & & & & B \\
\hline Hor N5A & Depth N5A & & Sand N5A & & Dia N5A \\
\hline $4 S C L$ & 255 & & 79 & 98 & \\
\hline $5 S$ & 345 & & & & B \\
\hline $6 \mathrm{MT}$ & 352 & & & & $\mathrm{Fb}$ \\
\hline $8 S C L$ & 498 & & 88 & 100 & \\
\hline
\end{tabular}




\begin{tabular}{|c|c|c|c|c|c|}
\hline Hor Net WW & Depth Net WW & LOI Net WW & Sand Net WW & Beach Net WW & \\
\hline OSCL & 73 & & 82 & 100 & \\
\hline 15 & 100 & 8.8 & & & \\
\hline $2 M T$ & 112 & 9.3 & & & \\
\hline $2 S$ & 119 & 15.8 & & & \\
\hline $3 \mathrm{MT}$ & 122 & 20 & & & \\
\hline $4 M T$ & 151 & 35.5 & & & \\
\hline $4 S$ & 170 & 7.7 & & & \\
\hline $4 S C L$ & 177 & & 85 & 100 & \\
\hline $5 \mathrm{MT}$ & 181 & 27.8 & & & \\
\hline $5 S$ & 190 & 3.4 & & & \\
\hline Hor OyF & Depth OyF & LOIOyF & Sand OyF & Beach OyF & Dia OyF \\
\hline OSCL & 92 & 3.2 & 84 & 100 & \\
\hline $1 \mathrm{MT}$ & 94 & 36.4 & & & \\
\hline 15 & 125 & 14.6 & & & \\
\hline $1 \mathrm{SCL}$ & 128 & & 83 & 100 & \\
\hline $2 M T$ & 134 & 21.3 & & & \\
\hline $2 S$ & 137 & 17 & & & \\
\hline $3 M T$ & 139 & 34.6 & & & \\
\hline $5 S C L$ & 302 & & 25 & 93 & \\
\hline $6 M T$ & 308 & & & & B \\
\hline $7 \mathrm{MT}$ & 345 & & & & $\mathrm{~F}$ \\
\hline 75 & 352 & & & & $\mathrm{~F}$ \\
\hline $8 M T$ & 355 & & & & $\mathrm{~F}$ \\
\hline Hor N10 & Depth N10 & & Sand N10 & Beach N10 & \\
\hline OSCL & 73 & & 56 & $1 \dot{6}$ & \\
\hline $1 \mathrm{MT}$ & 80 & & & 100 & \\
\hline 1S & 103 & & & 100 & \\
\hline $3 S C L$ & 143 & & 65 & 96 & \\
\hline $4 \mathrm{MT}$ & 146 & & & 100 & \\
\hline $4 S C L$ & 220 & & & 100 & \\
\hline $5 M T$ & 230 & & & 93 & \\
\hline
\end{tabular}


Horizon LNes5 Depth LNes 5 \%LOI LNes 5 \%Sand LNes 5 \%BeachLNes 5 Dia LNes 5

$\begin{array}{cccccc}\text { OMT } & 5 & 53 & 2 & & \\ \text { OS } & 44 & 26.5 & 6 & & \text { BF } \\ \text { 1MT } & 52 & 38.3 & 4 & 0 & \mathrm{~B} \\ \text { 1S } & 68 & 18 & 3 & & \mathrm{~B} \\ \text { 1SCL } & 70 & 22.3 & 27 & & \mathrm{~B} \\ \text { 2MT } & 74 & 34.8 & 1 & 0 & \mathrm{~B} \\ 2 \mathrm{~S} & 87 & 19.8 & 2 & & \\ 2 \mathrm{CL} & 89 & 21.3 & 51 & 0 & \mathrm{~B} \\ \text { 3MT } & 92 & 53.3 & 6 & & \\ \text { 3S } & 134 & 17.2 & 2 & 0 & \mathrm{~B} \\ 4 \mathrm{MT} & 163 & 19.8 & 2 & & \mathrm{~B} \\ 4 \mathrm{~S} & 172 & 19.8 & 2 & & \mathrm{~B} \\ 5 \mathrm{MT} & 194 & 38.4 & 1 & & \mathrm{~B} \\ 5 \mathrm{~S} & 262 & 14.7 & 1 & & \mathrm{Bf} \\ 6 \mathrm{MT} & 268 & 32 & 4 & & \mathrm{~B} \\ 6 \mathrm{~S} & 320 & 13.9 & 6 & & \mathrm{~B} \\ 7 \mathrm{MT} & 328 & 40.5 & 0 & & \mathrm{~B} \\ 7 \mathrm{~S} & 407 & 11.4 & 11 & 1 & \mathrm{Fb} \\ 7 \mathrm{SCL} & 412 & 8.8 & 55 & 8 & \\ 8 \mathrm{MT} & 421 & 19.5 & 3 & 0 & \\ 8 \mathrm{~S} & 467 & 22.6 & 0 & & \end{array}$




$\begin{array}{ccccc}\text { Hor LNes } 4 & \text { Depth LNes } 4 & \text { LOI LNes } 4 & \text { Sand LNes 4 } & \text { Beach LNes } 4 \\ \text { OS } & 25 & 21.7 & & \\ \text { 1MT } & 30 & 25.4 & & \\ \text { 2S } & 87 & 11.2 & & \\ \text { 3MT } & 92 & 22.6 & & \\ \text { 3S } & 107 & 16.3 & & \\ \text { 4S } & 187 & 23.7 & & \\ \text { 5MT } & 192 & 25 & & \\ \text { 5S } & 238 & 13 & & \\ \text { 6MT } & 242 & 22.8 & & \\ \text { 6S } & 290 & 10.5 & & \\ \text { 6SCL } & 298 & & & \\ \text { 7MT } & 310 & 17.9 & & \\ \text { 7S } & 350 & 8.7 & & \\ \text { 7SCL } & 360 & & 56 & \\ \text { 8MT } & 365 & 14.8 & 8 & \\ \text { 8S } & 420 & 4.2 & & \end{array}$

$\begin{array}{cccc}\text { Hor Nes 2 } & \text { Depth Nes 2 } & \text { Sand Nes 2 } & \text { Beach Nes 2 } \\ & 65 & 1 & 0 \\ \text { 2SCL } & 84 & 10 & 4 \\ \text { 3MT } & 91 & 8 & 0 \\ \text { 6S } & 312 & 2 & 0 \\ \text { 6SCL } & 320 & 38 & 0 \\ \text { 7MT } & 322 & 1 & 0 \\ \text { 7S } & 377 & 2 & 0 \\ \text { 7SCL } & 391 & 27 & 0 \\ \text { 8MT } & 394 & 3 & 0\end{array}$

$\begin{array}{ccccc}\text { Hor LNes 1 } & \text { Depth LNes 1 } & \text { LOI LNes 1 } & \text { Sand LNes 1 } & \text { Beach LNes 1 } \\ \text { OSCL } & 59 & & 18 & 1 \\ \text { 1MT } & 60 & & 11 & 8 \\ & 85 & 18.1 & & \\ & 120 & 13.1 & & \\ \text { 4SCL } & 172 & 4.1 & 69 & 20 \\ \text { 5MT } & 177 & & 10 & 2 \\ \text { 5S } & 290 & & 44 & \\ & & & & \\ \text { Hor LNes 2 } & \text { Depth LNes 2 } & \text { LOI LNes 2 } & \text { Sand LNes 2 } & \text { Beach LNes 2 } \\ \text { OS } & 40 & 10 & & \\ \text { OSCL } & 57 & & 66 & 7 \\ \text { 1MT } & 62 & & 27 & 1 \\ \text { 1S } & 82 & 10.5 & 24 & 0\end{array}$




\begin{tabular}{|c|c|c|c|c|}
\hline Hor NDuck 1 & Depth NDuck 1 & & Sand NDuck & 1 Beach NDuck1 \\
\hline OS & 65 & & 5 & 1 \\
\hline OSCL & 77 & & 63 & 39 \\
\hline OSCL & 85 & & 20 & 38 \\
\hline $1 \mathrm{MT}$ & 100 & & 50 & 9 \\
\hline Hor NDuck 2 & Depth NDuck 2 & & Sand NDuck & 2 Beach NDuck2 \\
\hline os & 65 & & 4 & 4 \\
\hline OSCL & 72 & & 86 & 13 \\
\hline $1 \mathrm{MT}$ & 80 & & 1 & 59 \\
\hline Hor NDuck 3 & Depth NDuck 3 & LOI NDuck 3 & Sand NDuck & 3 Beach NDuck 3 \\
\hline os & 66 & 9.7 & 14 & 5 \\
\hline OSCL & 72 & 1.8 & 87 & 76 \\
\hline $1 \mathrm{MT}$ & 78 & 26.6 & 3 & $<20$ \\
\hline Hor Hurl 1 & Depth Hurl 1 & LOl Hurl 1 & & \\
\hline OMT & 9 & 28.1 & & \\
\hline 15 & 67 & 17.9 & & \\
\hline 2MT & 72 & 29.7 & & \\
\hline $2 S$ & 108 & 18.6 & & \\
\hline 3MT & 138 & 36.1 & & \\
\hline $4 \mathrm{MT}$ & 172 & 34.5 & & \\
\hline Hor Hurl 3 & Depth Hurl 3 & LOl Hurl 3 & & \\
\hline $3 S$ & 143 & 11.7 & & \\
\hline $4 M T$ & 148 & 27.4 & & \\
\hline $4 S$ & 203 & 20.1 & & $\cdot$ \\
\hline 5MT & 210 & 33.2 & & \\
\hline $5 S$ & 250 & 8.8 & & \\
\hline $6 M T$ & 275 & 16.2 & & \\
\hline $6 S$ & 350 & 9.3 & & \\
\hline
\end{tabular}




\begin{tabular}{|c|c|c|c|c|c|}
\hline $\begin{array}{c}\text { Horizon Hur } 2 \\
\text { OMT }\end{array}$ & $\begin{array}{c}\text { Depth Hur } 2 \\
5\end{array}$ & $\begin{array}{c}\% \text { LOI Hur } 2 \\
36.3\end{array}$ & $\begin{array}{c}\% \text { Sand Hur } 2 \\
4\end{array}$ & \%Beach Hur2 & Dia Hur 2 \\
\hline os & 35 & 16.5 & 5 & & $B F$ \\
\hline $1 \mathrm{MT}$ & 42 & 31.6 & 3 & & $F$ \\
\hline is & 72 & 10.5 & 5 & & $\mathrm{Bf}$ \\
\hline $2 \mathrm{MT}$ & 78 & 25.2 & 4 & & BF \\
\hline $2 S$ & 150 & 8.3 & 7 & & B \\
\hline 3MT & 156 & 17.4 & 5 & & B \\
\hline $3 S$ & 172 & 18.1 & 7 & 0 & B \\
\hline $4 \mathrm{MT}$ & 178 & 33.8 & 8 & 18 & B \\
\hline $4 S$ & 215 & 11 & 3 & & B \\
\hline $5 \mathrm{MT}$ & 237 & 45.1 & 1 & & $F$ \\
\hline $5 S$ & 361 & 19.1 & 5 & & B \\
\hline $6 \mathrm{MT}$ & 365 & 29 & 3 & & B \\
\hline $6 S$ & 428 & 22.1 & 4 & & B \\
\hline 7MT & 436 & 31 & 3 & & B \\
\hline $7 S$ & 677 & 27.1 & 1 & & $B$ \\
\hline $8 \mathrm{MT}$ & 681 & 39.2 & 4 & & Fo \\
\hline $8 S$ & 762 & 27.2 & 4 & 7 & $B F$ \\
\hline 9MT & 767 & 35.5 & 5 & & FB \\
\hline $9 S$ & 960 & 11.6 & 2 & & B \\
\hline $10 \mathrm{MT}$ & 965 & 22.5 & 0 & & $B f$ \\
\hline $10 S$ & 1010 & 16.6 & 1 & & $B$ \\
\hline $11 \mathrm{MT}$ & 1015 & 27.8 & 2 & & B \\
\hline 115 & 1091 & 26 & 2 & & FB \\
\hline $11 \mathrm{SCL}$ & 1095 & 28.8 & 14 & 0 & $B F$ \\
\hline $12 M T$ & 1112 & 63.1 & 19 & 2 & FB \\
\hline $12 S$ & 1270 & 8.1 & 77 & 0 & $B$ \\
\hline
\end{tabular}




\begin{tabular}{|c|c|c|c|c|c|}
\hline $\begin{array}{c}\text { Horizon Sal H } \\
\text { OMT }\end{array}$ & $\begin{array}{c}\text { Depth Sal H } \\
5\end{array}$ & $\begin{array}{c}\% \text { LOI Sal H } \\
41.9\end{array}$ & $\begin{array}{c}\text { \%Sand Sal H } \\
64\end{array}$ & \%Beach Sal H & $\underset{B}{\text { Dia Sal H }}$ \\
\hline OS & 25 & 15 & 80 & 100 & B \\
\hline OSCL & 42 & 4.9 & 95 & 97 & \\
\hline $1 \mathrm{MT}$ & 48 & 18.4 & 16 & 96 & B \\
\hline $1 S$ & 60 & 21.9 & 100 & & B \\
\hline $2 \mathrm{MT}$ & 68 & 15.9 & 28 & & B \\
\hline $2 S$ & 105 & 7.1 & 3 & & B \\
\hline $3 M T$ & 111 & 11 & 19 & & B \\
\hline $3 S$ & 123 & 6.7 & 14 & & B \\
\hline $3 S C L$ & 158 & 4.8 & 88 & 98 & B \\
\hline $4 \mathrm{MT}$ & 169 & 14.3 & 7 & 94 & B \\
\hline $4 S$ & 188 & 13.2 & 1.4 & & B \\
\hline $4 S C L$ & 215 & 5.1 & 68 & 21 & B \\
\hline $5 \mathrm{MT}$ & 223 & 22.7 & 21 & 96 & $B$ \\
\hline $5 S$ & 258 & 13 & 19 & & B \\
\hline $5 \mathrm{SCL}$ & 265 & 1.8 & 95 & 97 & B \\
\hline $6 \mathrm{MT}$ & 272 & 11 & 80 & 96 & B \\
\hline $6 S$ & 310 & 1.4 & 95 & & B \\
\hline $7 M T$ & 320 & 5.9 & 85 & & B \\
\hline Horizon Mill & Depth Mill & $\%$ LOI Mill & $\%$ Sand Mill & $\%$ Beach Mill & Diatom Mill \\
\hline OMT & 5 & 25.9 & 13 & & B \\
\hline os & 37 & 15.2 & 3 & & $B$ \\
\hline $1 \mathrm{MT}$ & 48 & 19 & 6 & & $B$ \\
\hline $1 S$ & 78 & 5.5 & 13 & 0 & B \\
\hline $1 \mathrm{SCL}$ & 85 & 5.9 & 49 & 0 & \\
\hline $2 M T$ & 92 & 4.4 & 8 & & B \\
\hline $2 S$ & 125 & 7.3 & 16 & & B \\
\hline $2 S C L$ & 127 & 7.3 & 31 & 0 & \\
\hline $3 M T$ & 134 & 13.5 & 4 & 0 & B \\
\hline $3 S$ & 147 & 9.5 & 32 & & B \\
\hline $3 S C L$ & 154 & 6.9 & 52 & 0 & B \\
\hline 4MT & 158 & 12.4 & 2 & 0 & B \\
\hline $4 S$ & 192 & 10.8 & 4 & & B \\
\hline $4 S C L$ & 205 & 13.8 & 67 & 0 & B \\
\hline $5 M T$ & 209 & 17.5 & 2 & 0 & B \\
\hline $5 S$ & 237 & 9.8 & 43 & 0 & \\
\hline 6MT & 252 & 14.9 & 3 & & \\
\hline $6 S$ & 295 & 8.6 & 3 & 0 & B \\
\hline $6 S C L$ & 305 & 8 & 49 & 0 & B \\
\hline $7 \mathrm{MT}$ & 310 & 20.6 & 8 & 0 & B \\
\hline 75 & 361 & 12 & 2 & 0 & B \\
\hline
\end{tabular}




\begin{tabular}{|c|c|c|c|c|}
\hline $\begin{array}{l}\text { Hor Mill } 2 \\
\text { 3SCL }\end{array}$ & $\begin{array}{c}\text { Depth Mill } 2 \\
160\end{array}$ & LOI Mill 2 & $\begin{array}{c}\text { Sand Mill } 2 \\
53\end{array}$ & $\begin{array}{c}\text { Beach Mill } 2 \\
0\end{array}$ \\
\hline $4 M T$ & 170 & & 22 & $t r$ \\
\hline $4 \mathrm{SCL}$ & 205 & & 60 & 2 \\
\hline $5 \mathrm{MT}$ & 212 & & 3 & 1 \\
\hline $5 S$ & 227 & 9.7 & 6 & 0 \\
\hline $6 \mathrm{MT}$ & 232 & 10.6 & 14 & 0 \\
\hline $6 S C L$ & 290 & & 68 & 0 \\
\hline Hor SilR & Depth SilR & & Sand SilR & Beach SilR \\
\hline OSCL & 45 & & 34 & 0 \\
\hline $1 \mathrm{MT}$ & 52 & & 8 & \\
\hline Hor Alder & Depth Alder & & Sand Alder & Beach Alder \\
\hline 15 & 74 & & 1 & 0 \\
\hline $1 S C L$ & 87 & & 34 & 0 \\
\hline $2 \mathrm{MT}$ & 92 & & 4 & $\operatorname{tr}$ \\
\hline Hor Mill CB5 & Depth Mil CB5 & & Sand Mill CBS & Beach MillCB5 \\
\hline OSCL & 82 & & 60 & 0 \\
\hline $1 \mathrm{MT}$ & 84 & & 17 & 0 \\
\hline
\end{tabular}




\begin{tabular}{|c|c|c|c|c|c|}
\hline Horizon Slack & Depth Slack & \%LOI Slack & $\%$ Sand Slack & \%Beach Slack & Dia Slack \\
\hline OMT & 5 & 13.6 & 16 & & \\
\hline OSCL & 35 & & 68 & & \\
\hline O'MT & 40 & & 17 & & \\
\hline $0^{\prime} S$ & 85 & & 14 & & \\
\hline TMT & 87 & & 2 & & \\
\hline is & 105 & 18 & 1 & & \\
\hline $2 M T$ & 111 & 33 & 1 & & \\
\hline $2 S$ & 154 & 9.8 & 27 & & $\mathrm{Fb}$ \\
\hline 3MT & 167 & 23.4 & 8 & & $F$ \\
\hline $3 s$ & 178 & 9.8 & 5 & & $f b$ \\
\hline $4 \mathrm{MT}$ & 188 & 14.2 & 5 & & FB \\
\hline $4 S$ & 230 & 5.6 & 26 & & \\
\hline 5MT & 255 & 9.7 & 17 & & $\mathrm{~B}$ \\
\hline $5 S$ & 287 & 6 & 71 & 0 & b \\
\hline $6 \mathrm{MT}$ & 295 & 17.5 & 12 & 0 & $\mathrm{~F}$ \\
\hline $6 S$ & 328 & 8.7 & 20 & & FB \\
\hline $7 M T$ & 340 & 15.3 & 9 & & \\
\hline 75 & 386 & 8.9 & 6 & & $\mathrm{~F}$ \\
\hline 7SCL & 392 & 9.2 & 72 & 0 & \\
\hline 8MT & 395 & 12.6 & 9 & 0 & $f b$ \\
\hline $8 S$ & 416 & 11.4 & 3 & & $B$ \\
\hline $8 S C L$ & 428 & 11.4 & 13 & 0 & B \\
\hline $9 \mathrm{MT}$ & 436 & 19.6 & 3 & 0 & $f b$ \\
\hline 9S & 504 & 7.9 & 16 & & bf \\
\hline 10MT & 513 & 11.4 & 13 & & B \\
\hline $10 \mathrm{~S}$ & 543 & 10.3 & 16 & & B \\
\hline $10 \mathrm{SCL}$ & 581 & 11 & 54 & $0^{\circ}$ & b \\
\hline $11 \mathrm{MT}$ & 593 & 16.1 & 3 & 0 & B \\
\hline Hor Con 2 & Depth Con 2 & LOI Con 2 & Sand Con 2 & & \\
\hline os & 20 & 17.9 & 1 & & \\
\hline $1 \mathrm{MT}$ & 25 & 33.1 & 1 & & \\
\hline $2 S$ & 44 & 19.3 & 1 & & \\
\hline $3 \mathrm{MT}$ & 46 & 26.3 & 1 & & \\
\hline $3 S$ & 88 & 18.7 & 0 & & \\
\hline \multicolumn{3}{|c|}{ Hor Slack CBCDepth Slk CBC } & Sand SIk CBC & & \\
\hline os & 35 & & 68 & & \\
\hline O'MT & 40 & & 17 & & \\
\hline $\mathbf{S}$ & 43 & & 52 & & \\
\hline MT & 47 & & 20 & & \\
\hline O'S & 85 & & 14 & & \\
\hline $1 \mathrm{MT}$ & 87 & & 2 & & \\
\hline
\end{tabular}




$\begin{array}{cccccc}\text { Horizon Hat } & \text { Depth Hat } & \% \text { LOI Hat } & \text { \%Sand Hat } & \text { \%Beach Hat } & \text { Dia Hat } \\ \text { OMT } & 5 & 21.3 & 6 & & \text { FB } \\ \text { OS } & 27 & 14.5 & 8 & & \text { B } \\ \text { OSCL } & 29 & 1.3 & 79 & 100 & \text { B } \\ \text { O'MT } & 33 & 12.8 & 7 & 100 & \text { B } \\ \text { 2SCL } & 72 & 4.4 & 78 & 100 & \text { B } \\ \text { 3MT } & 78 & 11.6 & 38 & 100 & \text { B } \\ \text { Horizon Oyst } & \text { Depth Oyst } & \text { \% LOI Oyst } & \text { \% Sand Oyst } & \text { \% Beach Oyst } & \text { Diatom Oyst } \\ \text { OMT } & 5 & 39.7 & 1 & & \text { B } \\ \text { OS } & 27 & 8.8 & 1 & & \text { B } \\ \text { O'MT } & 33 & 17.2 & 0 & & \text { B } \\ \text { O'S } & 70 & 14.6 & 0 & & \text { B } \\ \text { 1MT } & 78 & 18.8 & 0 & & \text { B } \\ \text { 1S } & 158 & 4.9 & 23 & 0 & \text { B } \\ \text { 2MT } & 167 & 8.5 & 4 & 0 & \end{array}$




\section{APPENDIX G}

DIATOM AND SALT MARSH PLANT SPECIES 
Diatoms

Salt marsh species (c)

a) Patrick and

Reimer, 1986
Freshwater (a)

Melosira sp.

Pinnularia sp.

Cymbella sp.

Eunotia SR.

Epithemian so.

Tabularia sp.

Gomphonema sp.

Stauroneis Sp.

Low marsh

Distichlis spicata

Scirpus americanus

Salicornia virginica

Iriglochin maritimum

b) Whiting and

McIntire, 1985
Brackish/Marine (b)

Paralia sulcata

Biddulphia aurita

Grammatophora so.

Coscinodiscus sp.

Actinoptychus sp.

Camplyodiscus SR.

Navicula pusilla

Nitzchia trybionella

Diploneis bombus

Melosira nummuloides

Auliscus So.

Aulacodiscus sp.

Epithemia turgida

High marsh

Deschampsia

caespitosa

Potentilla pacifica

Grindelia integrifolia

Juncus balticus

c) Jefferson, 1975 